\title{
MAPPING THE RISK OF BREAST CANCER TO EXPOSURE FROM TRAFFIC-RELATED AIR POLLUTION USING LAND-USE REGRESSION IN \\ VANCOUVER, B.C.
}

\begin{abstract}
by
Nicollette Kyunghee Kwon

A thesis submitted to the Department of Public Health Sciences

In conformity with the requirements for

the degree of Master of Science
\end{abstract}

\author{
Queen's University \\ Kingston, Ontario, Canada
}

February, 2015

Copyright (C) Nicollette Kyunghee Kwon, 2015 


\begin{abstract}
An environmental role in breast cancer etiology has been suspected but evidence is still inconclusive. Traffic-related air pollution is a potentially modifiable risk factor that has been studied in the etiology of breast cancer. Two Canadian studies using similar methodology to this study have recently reported positive associations between exposure to nitrogen dioxide $\left(\mathrm{NO}_{2}\right)$, a proxy for traffic-related air pollution, and breast cancer.

This thesis used land-use regression to estimate $\mathrm{NO}_{2}$ exposure for 2,015 women recruited from Vancouver, British Columbia (BC) into a population-based case-control study conducted in 2005-2010. Cases were recruited from the BC Cancer Agency and controls from the Screening Mammography Program of BC. Cross-sectional and historical analyses were conducted using $\mathrm{NO}_{2}$ estimated at time of study entry and ten years prior to study entry, respectively. Logistic regression models were created to estimate the relationship between exposure to $\mathrm{NO}_{2}$ and breast cancer, adjusting for breast cancer risk factors and stratified by menopausal status. Sensitivity analyses were conducted, assessing potential biases introduced by screening mammography program attendance and immigrant status, among others.
\end{abstract}

The analysis at study entry included 964 cases and 945 controls. No association between $\mathrm{NO}_{2}$ exposure (per $5 \mathrm{ppb}$ increases) and risk of breast cancer was observed in the postmenopausal sample at study entry or at ten years prior to study entry. A consistent positive association in premenopausal women was observed at study entry $(\mathrm{OR}=1.17,95 \% \mathrm{CI}$ : 0.93 , $1.48)$ and ten years prior to study entry $(\mathrm{OR}=1.18,95 \% \mathrm{CI}: 0.93,1.49)$. The association between historical estimates of $\mathrm{NO}_{2}$ (per 5 ppb increases) and breast cancer was stronger in a sensitivity 
analysis excluding cases who had not attended screening mammography in the premenopausal sample (OR=1.20, 95\% CI: $0.91,1.59)$.

This study adds to the growing literature on exposure to traffic-related air pollution and breast cancer incidence. The results provide some support for the hypothesis that increased exposure may be associated with breast cancer, particularly in premenopausal women, although bias may have been introduced due to the selection of controls from a screening mammography program and low response rates. Future research, especially using prospective cohort studies, is needed. 


\section{Co-Authorship}

This thesis represents the work of Nicollette Kwon in collaboration with her supervisors,

Dr. Harriet Richardson, Dr. Michael McIsaac, and Dr. Dongmei Chen with additional input from

Dr. Kristan J. Aronson, Dr. John J. Spinelli, and Dr. Mark Goldberg. The original study was designed and coordinated by Kristan Aronson, John Spinelli, Chris Bajdik, Angela BrooksWilson, Harriet Richardson, Igor Burstyn, Pierre Ayotte, Caroline Lohrisch, Sandip SenGupta, and Agnes Lai. 


\section{Acknowledgements}

I am extremely grateful to my supervisors, Dr. Harriet Richardson, Dr. Michael McIsaac, and Dr. Dongmei Chen, for all their knowledge, guidance, patience and support during my thesis. Harriet, thank you for taking me on as a student and embarking on this traffic-related air pollution journey with me - I don't think either of us could have predicted how much we would have to learn along the way. Michael, thank you for generously sharing with us your statistical wisdom and truly higher-level thinking. Dongmei, thank you for always being so welcoming and giving me a place in your lab. I would also like to thank Dr. Kristan Aronson and Dr. John Spinelli for their insight and assistance at all stages of this project. I gratefully acknowledge as well Dr. Michael Brauer for his extremely prompt and detailed email replies and contribution of the land-use regression used in this project; Dr. Mark Goldberg and Marcela Rivera for their guidance during the proposal phases of this project, all without whom this project would never have gotten off the ground; and Dr. Anne Grundy, who navigated us through the complex CBCS dataset and was always happy to answer long-winded questions about breast cancer.

My supervisors and I would also like to thank Dr. Linda Warren (Screening Mammography Program of BC), Dr. Philip Switzer (Greig Associates), Caroline Speers (Breast Cancer Outcomes Unit, BC Cancer Agency), Agnes Bauzon, Alegria Imperial, Betty Hall, Lina Hsu, Maria Andrews, Teresa Pavlin, and Agnes Lai for their assistance with participant recruitment and data collection in Vancouver.

I also gratefully acknowledge CIHR for their funding of the original Canadian Breast Cancer Study, as well as my funding sources: the Queen's University Department of Public Health Sciences and the Terry Fox Foundation Transdisciplinary Training Program in Cancer 
Research in partnership with CIHR, and the study participants in the Canadian Breast Cancer Study.

I thank the faculty, staff, and students at the Department of Public Health Sciences for providing the very best education, support, and environment to grow in.

Finally, I would like to acknowledge all of my personal sources of motivation and support. I am extremely grateful to my parents, brother, and friends who have been by my side and have been so supportive of me. I would like to especially acknowledge Haley for being the best roommate ever; Hikaru and Victoria, even though we are now separated, we'll always be together; the girls in my MSc class, especially Heather and Asha, our adventures were amazing!; the "first-years" who kindly adopted me as one of their own and "eng" Katherine who we adopted into epid; everyone in the best (but mostly at procrastination) pod at CCE: Sue, Erin, Joy, and Olivia; and Michael who was an exceptional source of love, motivation, and encouragement. 


\section{Table of Contents}

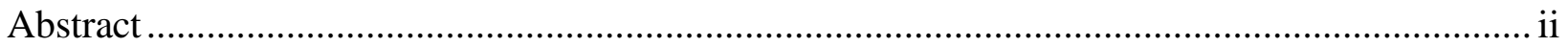

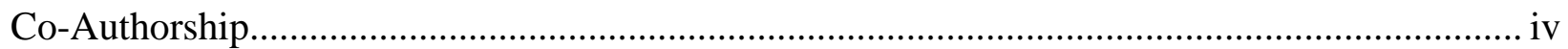

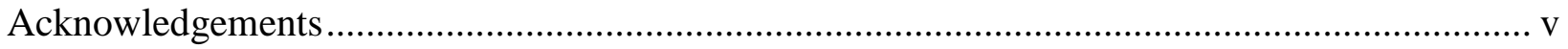

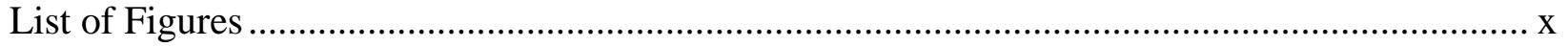

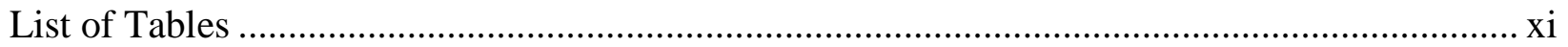

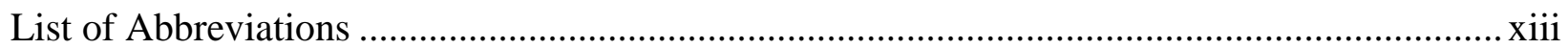

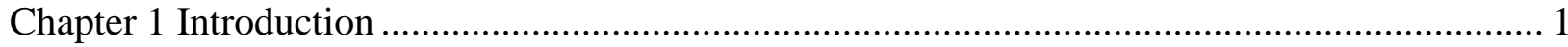

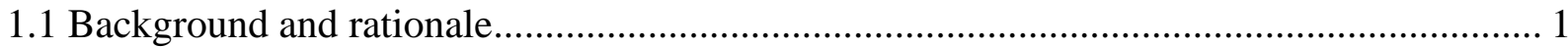

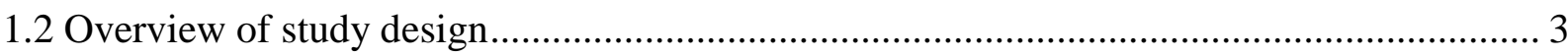

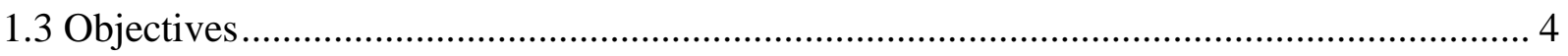

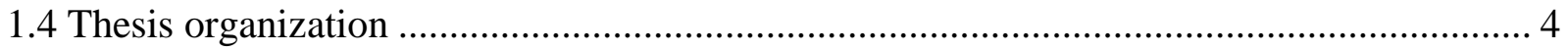

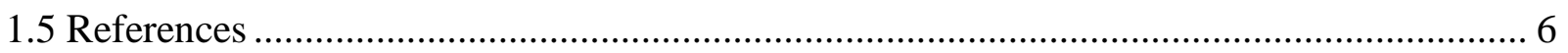

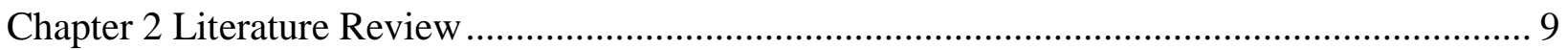

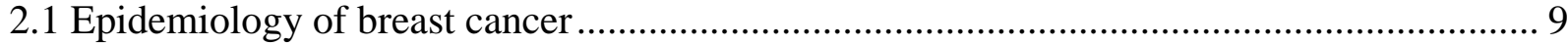

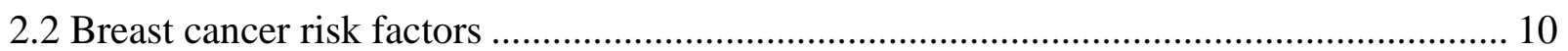

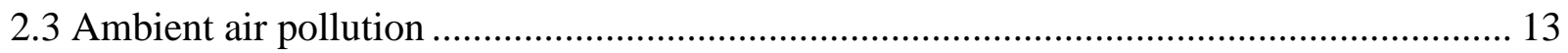

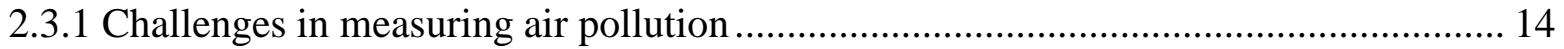

2.3.2 Determinants of traffic-related air pollution..................................................... 16

2.4 Traffic-related air pollution and breast cancer ...................................................... 16

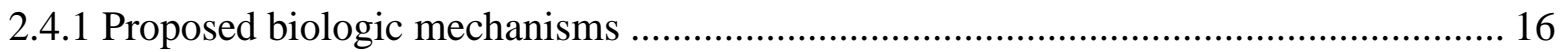

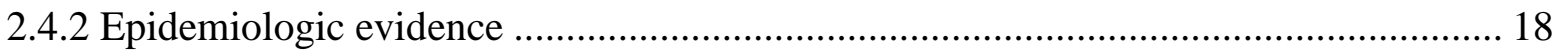

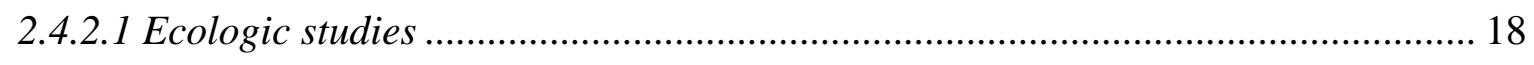

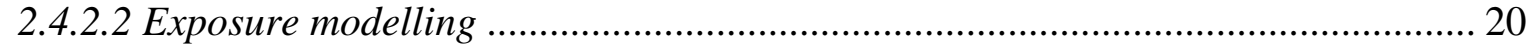

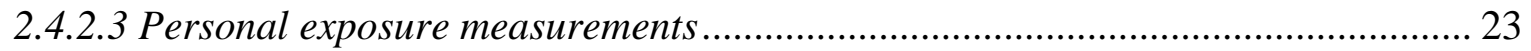

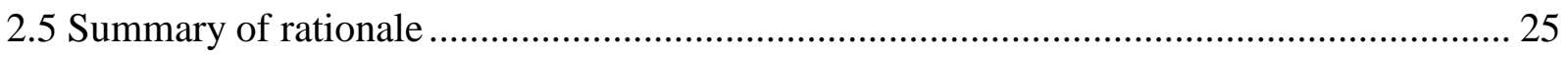

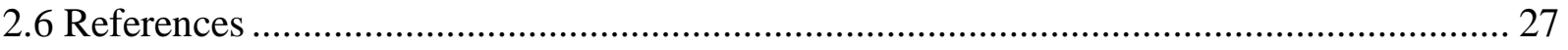

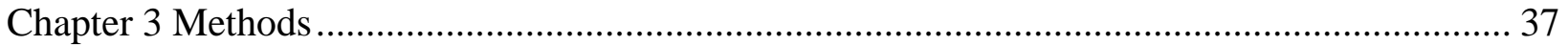

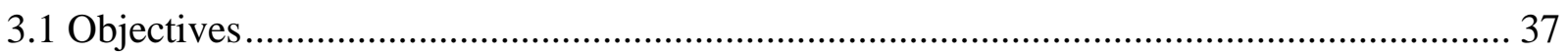

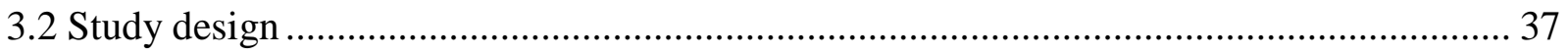




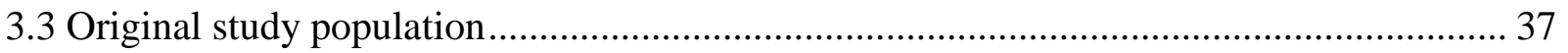

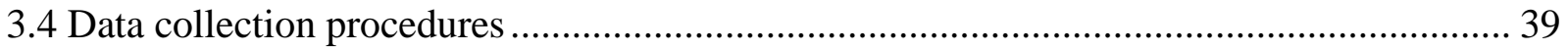

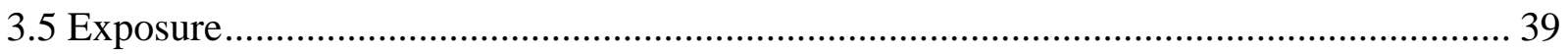

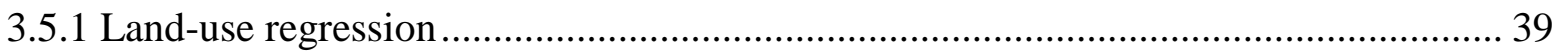

3.5.2 Back-extrapolation of the land-use regression model .................................................. 43

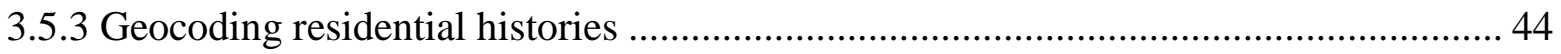

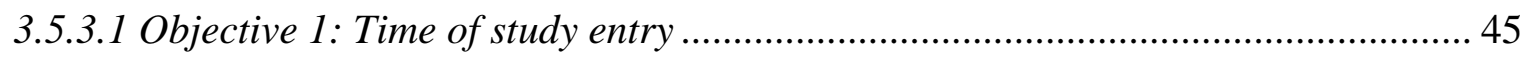

3.5.3.2 Objective 2: Ten-year latency ...................................................................... 45

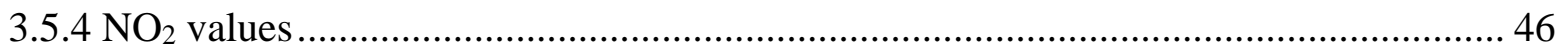

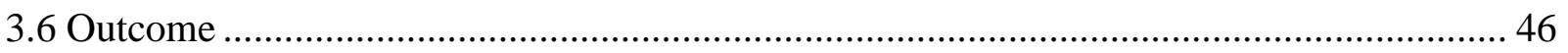

3.7 Menopausal status …………………………………............................................. 47

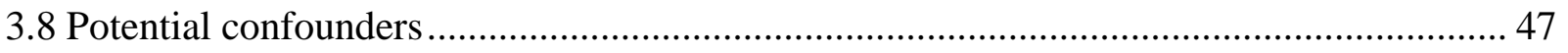

3.8.1 Demographics .................................................................................................... 48

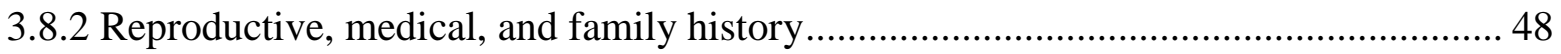

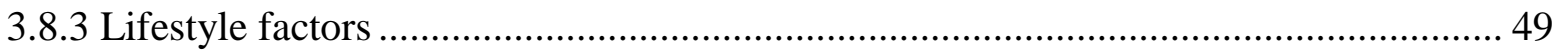

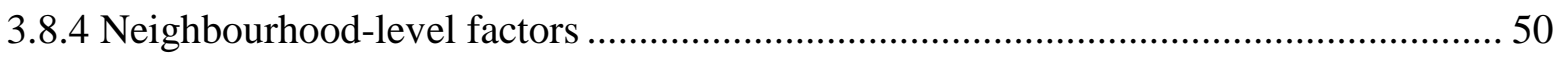

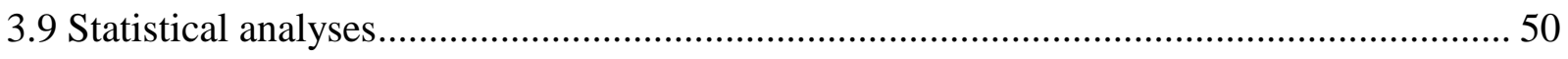

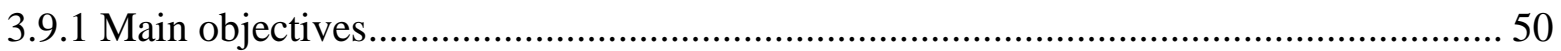

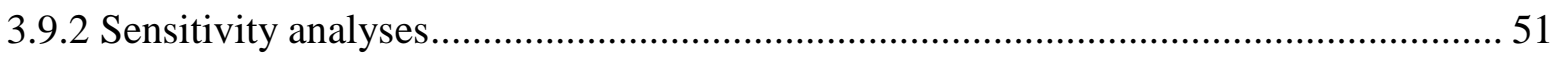

3.9.2.1 Exclusion of cases with diagnosis dates greater than two years from study entry 51

3.9.2.2 Exclusion of participants with more than one residence in the ten years prior to

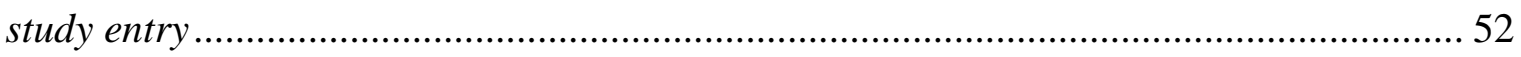

3.9.2.3 Exclusion of cases who have never attended screening mammography............... 52

3.9.2.4 Exclusion of participants who were not born in Canada .................................... 52

3.9.2.5 Exclusion of participants who never attended screening mammography and who

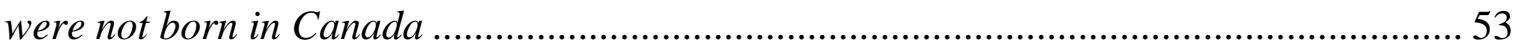

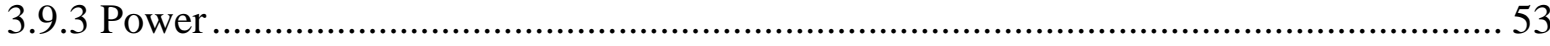

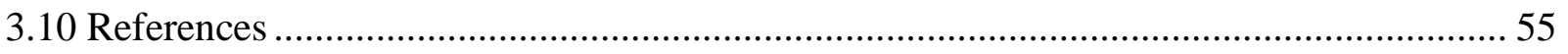

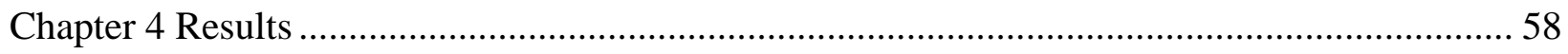

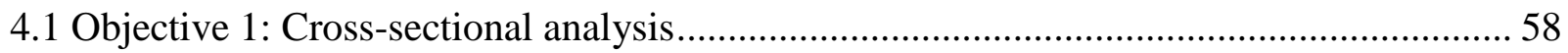

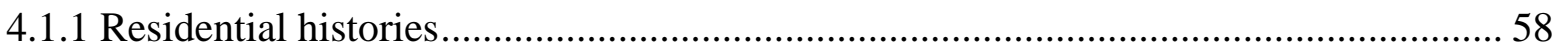


4.1.2 $\mathrm{NO}_{2}$ 60

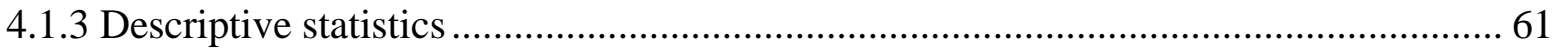

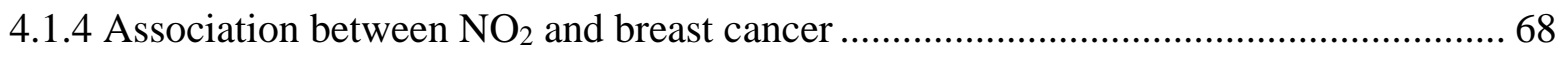

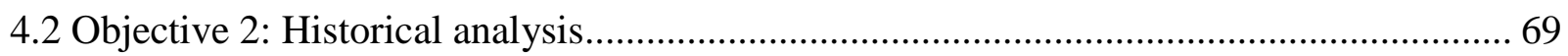

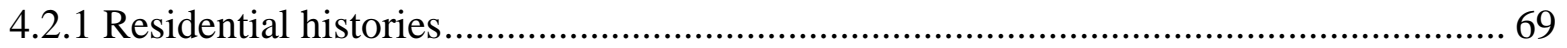

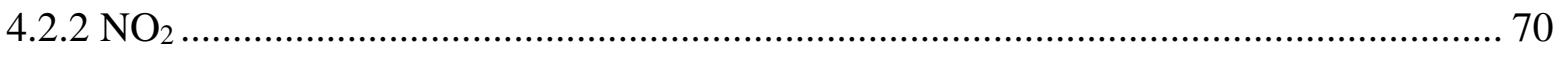

4.2.3 Association between $\mathrm{NO}_{2}$ and breast cancer ............................................... 71

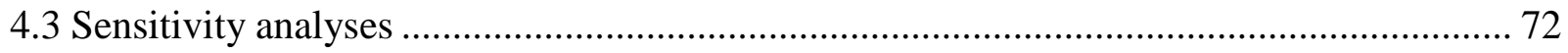

4.3.1 Exclusion of cases with diagnosis dates greater than two years from study entry ....... 72

4.3.2 Exclusion of participants with more than one residence in the ten years prior to study

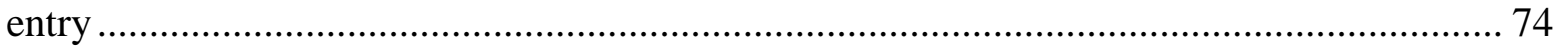

4.3.3 Exclusion of cases who have never attended screening mammography ................... 76

4.3.4 Exclusion of participants who were not born in Canada ........................................ 77

4.3.5 Exclusion of participants who have never attended screening mammography and who

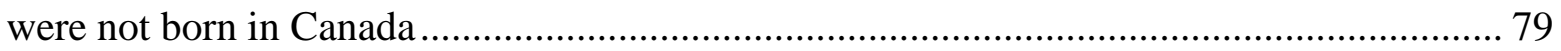

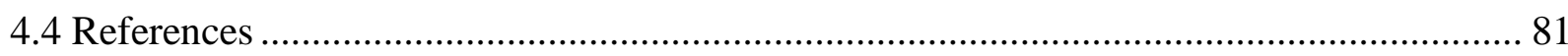

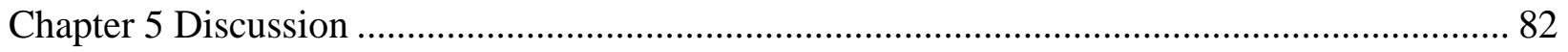

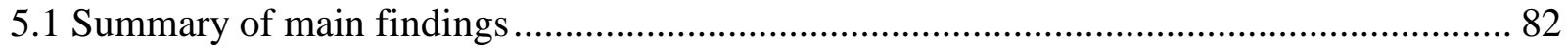

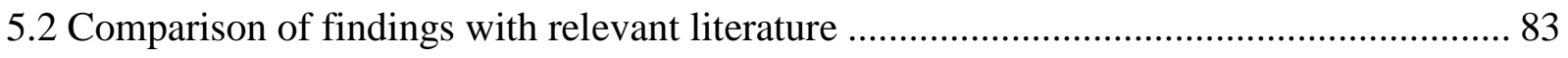

5.3 Study validity: Methodological strengths and limitations .......................................... 90

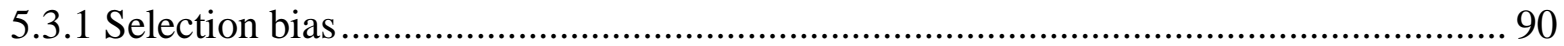

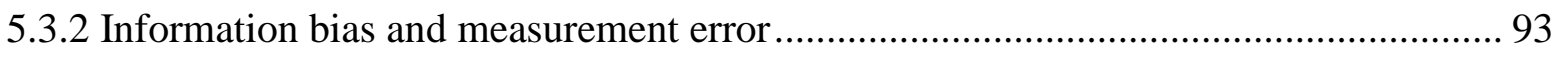

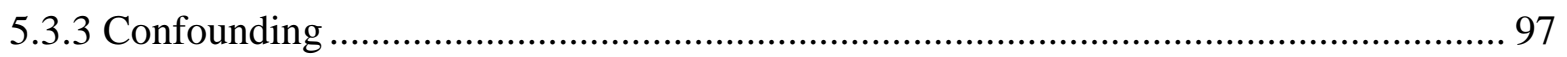

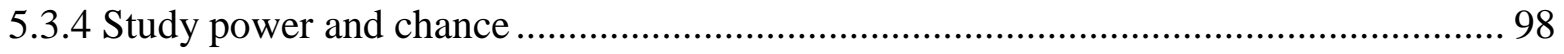

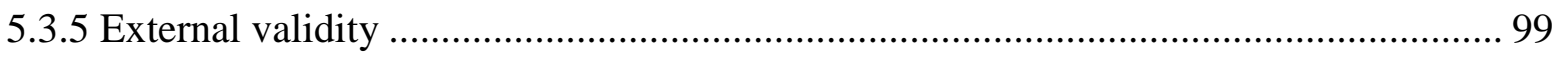

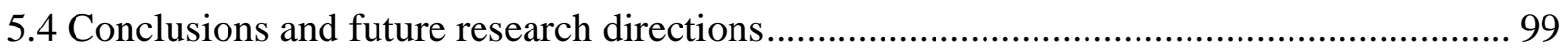

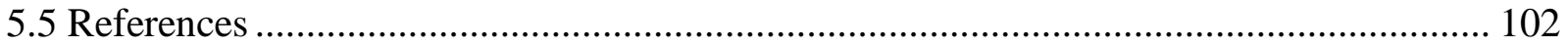

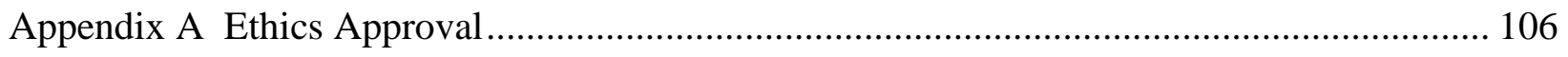

Appendix B Canadian Breast Cancer Study Questionnaire ................................................. 109

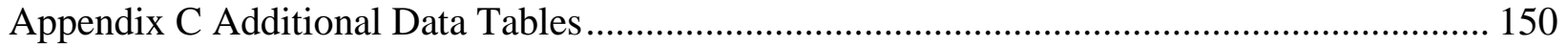




\section{List of Figures}

Figure 3-1: The $2003 \mathrm{NO}_{2}$ land-use regression model for Metro Vancouver .....

Figure 3-2: The inverse-distance weighted (IDW) interpolated surface for 1995 (marked by a red

border) laid on top of the LUR model with monitors shown (yellow dots) 46 


\section{List of Tables}

Table 3-1: Land-use regression model equations ${ }^{*}$ using two separate traffic metrics .................. 41

Table 3-2: Formula used for back-extrapolating in time, derived from Chen et al. (7)................ 44

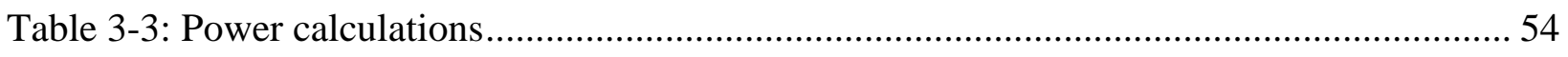

Table 4-1: Number of cases and controls with varying number of street addresses in 10,20, and 30 years before study entry in the original study population (1,001 cases and 1,014 controls) ... 59 Table 4-2: Frequency table of reasons for excluded cases and controls for objective 1 .............. 59 Table 4-3: Average $\mathrm{NO}_{2}$ levels in parts-per-billion (ppb) for post- and premenopausal women. 60 Table 4-4: Characteristics of the study population for postmenopausal and premenopausal women for all covariates by case and control status

Table 4-5: Age-adjusted and fully-adjusted models for association between $\mathrm{NO}_{2}$ exposure and breast cancer with odds ratios per $5 \mathrm{ppb}$ increases in $\mathrm{NO}_{2}\left(\mathrm{OR}_{5 \mathrm{ppb}}\right)$.......................................... 68 Table 4-6: Frequency table of excluded cases and controls with reasons for objective 2 ............ 69 Table 4-7: $\mathrm{NO}_{2}$ means, standard deviations, and medians in parts-per-billion (ppb) for post- and

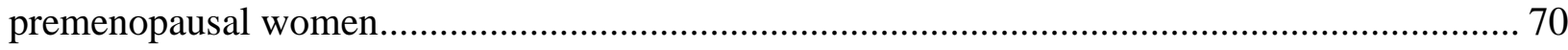
Table 4-8: Age-adjusted and fully-adjusted models for association between $\mathrm{NO}_{2}$ exposure and breast cancer with odds ratios per $5 \mathrm{ppb}$ increases in $\mathrm{NO}_{2}\left(\mathrm{OR}_{5 \mathrm{ppb}}\right)$......................................... 71 Table 4-9: Age-adjusted and fully-adjusted logistic regression models excluding cases with diagnosis dates greater than two years from study entry using $\mathrm{NO}_{2}$ estimates at study entry (Table 4-9A) and back-extrapolated historical $\mathrm{NO}_{2}$ estimates (Table 4-9B)

Table 4-10: Age-adjusted and fully-adjusted logistic regression models excluding participants with more than one address in the ten years from study entry using $\mathrm{NO}_{2}$ estimates at study entry (Table 4.10A) and back-extrapolated historical $\mathrm{NO}_{2}$ estimates (Table 4.10B) ....

Table 4-11: Age-adjusted and fully-adjusted logistic regression models excluding cases who have never attended screening mammography using $\mathrm{NO}_{2}$ estimates at study entry (Table 4.11A) and back-extrapolated historical $\mathrm{NO}_{2}$ estimates (Table 4.11B)

Table 4-12: Age-adjusted and fully-adjusted logistic regression models excluding participants not born in Canada using $\mathrm{NO}_{2}$ estimates at study entry (Table 4.12A) and back-extrapolated historical $\mathrm{NO}_{2}$ estimates (Table 4.12B) 
Table 4-13: Age-adjusted and fully-adjusted logistic regression models excluding participants who have never attended screening mammography and who were not born in Canada using $\mathrm{NO}_{2}$ estimates at study entry (Table 4.13A) and back-extrapolated historical $\mathrm{NO}_{2}$ estimates (Table 4.13B).

Table C-1: Bivariate analyses for post- and premenopausal women for all covariates, except age (matching variable) 150 


\section{List of Abbreviations}

\begin{tabular}{|c|c|}
\hline AIC & Akaike information criterion \\
\hline $\mathrm{BaP}$ & Benzo[a]pyrene \\
\hline $\mathrm{BC}$ & British Columbia \\
\hline BMI & Body-mass index \\
\hline CBCS & Canadian Breast Cancer Study \\
\hline $\mathrm{CI}$ & Confidence interval \\
\hline DNA & Deoxyribonucleic acid \\
\hline ELISA & Enzyme-linked immunosorbent assay \\
\hline ER & Estrogen receptor \\
\hline IARC & International Agency for Research on Cancer \\
\hline ICD & International classification of diseases \\
\hline IDW & Inverse-distance weighted \\
\hline GIS & Geographic information systems \\
\hline GPS & Global positioning system \\
\hline HER2 & Human epidermal growth factor receptor 2 \\
\hline HRT & Hormone replacement therapy \\
\hline LUR & Land-use regression \\
\hline$\mu \mathrm{g} / \mathrm{m}^{3}$ & micrograms per cubic meter \\
\hline $\mathrm{OC}$ & Oral contraceptive \\
\hline OR & Odds ratio \\
\hline $\mathrm{OR}_{5 \mathrm{ppb}}$ & Odds ratio per $5 \mathrm{ppb}$ increases \\
\hline NO & Nitric oxide \\
\hline NO2 & Nitrogen dioxide \\
\hline NOx & Nitrogen oxides \\
\hline NY & New York \\
\hline PAH & Polycyclic aromatic hydrocarbon \\
\hline $\mathrm{ppb}$ & parts-per-billion \\
\hline PR & Progesterone receptor \\
\hline $\mathrm{RR}$ & Relative risk \\
\hline SES & Socio-economic status \\
\hline SD & Standard deviation \\
\hline SMP & Screening Mammography Program \\
\hline TSP & Total suspended particulates \\
\hline WEB & Western New York Exposures and Breast Cancer \\
\hline
\end{tabular}




\section{Chapter 1}

\section{Introduction}

\subsection{Background and rationale}

Breast cancer is the most common invasive cancer and the second-leading cause of cancer deaths among Canadian women (1). It is estimated that only one-third to one-half of new cases of breast cancer are attributable to the current established risk factors (2). These risk factors include demographic and socio-economic factors, reproductive factors, family history, and lifestyle factors, such as alcohol consumption, weight and height, and use of exogenous hormones (3). Occupational and environmental exposures that may have a possible role in breast cancer incidence have also been considered (2). A higher proportion of breast cancer cases may be attributable to the interaction of various lifestyle risk factors and environmental or occupational exposures (2). Most of these risk factors confer very modest elevated risks (except family history of breast cancer, ionizing radiation, benign breast disease, and breast density) (3). This establishes a need for additional research into other possible etiologic agents and environmental exposures, such as traffic-related air pollution.

Several ecologic studies have shown elevated risks for developing breast cancer in areas of high urbanization (4-6), and therefore, higher exposures of traffic-related air pollution, industrial pollutants, and other environmental toxins. Significantly higher risks of breast cancer were observed for clusters within southern Ontario: specifically, in the counties of Toronto and Niagara, there were elevated relative risks ranging from 1.15 to 1.29 (5). These risks may be attributable to higher levels of industrial pollution or agricultural chemicals such as pesticides and fungicides (5). Regional variation in breast cancer risk has also been observed in the United 
States (7). A study using ecologic-level data of air pollutant emissions and breast cancer incidence rates observed incidence rates of breast cancer to be significantly higher in metropolitan areas compared to non-metropolitan areas (8).

In October of 2013, the International Agency for Research on Cancer (IARC) announced outdoor air pollution as a Group 1 definite carcinogen to humans (9). IARC concluded that there is sufficient evidence that exposure to air pollution causes lung cancer and also evidence of an increased risk of bladder cancer (9). Outdoor air pollution is an incredibly widespread environmental carcinogen which also has a conclusive and causal negative impact on general health.

Historically, exposure to air pollution has been associated with increased risks for lung cancer (10) and respiratory diseases $(10,11)$, but there is now emerging evidence to suggest an association between traffic-related air pollution and increased risks for breast cancer $(8,12-15)$, as well as brain (15) and cervical cancer (15). Components of traffic-related air pollution, polycyclic aromatic hydrocarbons (PAHs), have been suggested to be the biologic agents in breast cancer carcinogenesis (14,16-18). Several PAHs, including benzo[a]pyrene and dibenzo[a,l]pyrene, are well-established mammary carcinogens in animal models (18). As traffic-related air pollution is an extremely ubiquitous exposure, its potential carcinogenicity has a wide-reaching audience and therefore, is a public health concern.

This will be the third Canadian study which uses an exposure assessment method known as land-use regression (LUR) to assess the relationship between traffic-related air pollution and breast cancer. The first was a study conducted in Montreal, Quebec by Crouse et al. which assessed the risk of air pollution on postmenopausal breast cancer. An odds ratio (OR) of 1.31 was observed for every 5 parts-per-billion $(\mathrm{ppb})$ increase in estimated nitrogen dioxide $\left(\mathrm{NO}_{2}\right)$ 
exposure at time of study entry $\left(\mathrm{OR}_{5 \mathrm{ppb}}=1.31,95 \%\right.$ confidence interval $\left.(\mathrm{CI}): 1.00,1.71\right)(14)$.

The second study was based on data collected from a national case-control study conducted between 1994 and 1997 (19). Hystad and collaborators (20) used three different exposure measures to characterize exposure to traffic-related air pollution: two involving satellite-derived observations and the third using a national land-use regression model. The study reported an odds ratio of 1.07 per 10 ppb increases in $\mathrm{NO}_{2}(95 \% \mathrm{CI}: 0.86,1.32)$ for postmenopausal breast cancer and an odds ratio of 1.28 per 10 ppb increases in $\mathrm{NO}_{2}(95 \% \mathrm{CI}: 0.92,1.79)$ for premenopausal breast cancer using the land-use regression estimates for exposure. In this thesis project, exposure to $\mathrm{NO}_{2}$ at time of study entry and at ten years prior to study entry will be derived from a land-use regression model created by Henderson et al. in 2003 (21).

Similar to the study in Montreal, odds ratios for $5 \mathrm{ppb}$ increases in $\mathrm{NO}_{2}$ exposure will be calculated for the sample of women; analyses will be stratified by menopausal status to make direct comparisons to the Montreal sample of postmenopausal women and both samples of premenopausal and postmenopausal women in the national study, as well as to assess risk of breast cancer by menopausal status in Vancouver women.

\subsection{Overview of study design}

This study attempts to further understand the possible role of traffic-related air pollution in the etiology of breast cancer using an exposure assessment method known as land-use regression to assign air pollution exposure to women with and without breast cancer. These women were recruited into the Canadian Breast Cancer Study (formerly known as the Molecular Epidemiology Breast Cancer study), which was a case-control study conducted in Vancouver, British Columbia and in Kingston, Ontario by Aronson et al., from 2005 to 2010. It aimed to 
identify genetic, lifestyle, and environmental risk factors for breast cancer. Participants were given a questionnaire to complete and a blood or saliva sample was collected. In this thesis project, only women from Vancouver will be included in the analysis.

\subsection{Objectives}

The primary objective of this thesis was to assess the association between traffic-related air pollution exposure and breast cancer. This association was examined using exposures estimated separately at two time points (at study entry and ten years prior to study entry) to assess the latency in breast cancer development. This thesis also describes the differences in identified risk factors for breast cancer among cases and controls. Several sensitivity analyses were conducted to assess the effects of certain methodological decisions. Specifically, these include analyses excluding cases who had entered the study after two years of their diagnosis of breast cancer to address potential "incidence-prevalence" bias, excluding participants with more than one residence for the ten years before their study entry to reduce misclassification based on address, excluding cases who had never attended screening mammography to reduce potential selection bias, and excluding participants who were not born in Canada to reduce the "healthy immigrant" effect.

\subsection{Thesis organization}

The second chapter in this thesis reviews the current body of literature on the relationship between breast cancer and traffic-related air pollution. It also describes factors which are independently associated with breast cancer and traffic-related air pollution, as well as 
challenges in assessing exposure to air pollution. The third chapter outlines data collection procedures, methods used by Henderson et al. (21) to create the land-use regression model, geospatial programming to assess $\mathrm{NO}_{2}$ exposure, categorization of all covariates, and statistical analyses used in examining the relationship between breast cancer and traffic-related air pollution. The fourth chapter describes the results of the data analysis objectives. The fifth and last chapter contains a general discussion on the findings in the fourth chapter, as well as strengths and limitations of this thesis project, future research directions, and overall conclusions. 


\subsection{References}

1. Canadian Cancer Society's Advisory Committee on Cancer Statistics. Canadian Cancer Statistics 2014. Toronto, ON: Canadian Cancer Society; 2014.

2. Coyle YM. The effect of environment on breast cancer risk. Breast Cancer Res Treat 2004;84(3):273-288.

3. Weiderpass E, Meo M, Vainio H. Risk factors for breast cancer, including occupational exposures. Safety and health at work 2011;2(1):1-8.

4. Dey S, Soliman AS, Hablas A, Seifeldin IA, Ismail K, Ramadan M, et al. Urban-rural differences in breast cancer incidence by hormone receptor status across 6 years in Egypt. Breast Cancer Res Treat 2010;120(1):149-160.

5. Luginaah IN, Gorey KM, Oiamo TH, Tang KX, Holowaty EJ, Hamm C, et al. A geographical analysis of breast cancer clustering in southern Ontario: generating hypotheses on environmental influences. Int J Environ Health Res 2012;22(3):232-248.

6. Meijer H, Huveneers J, Kiemeney L. Urban-Rural Differences in Cancer Incidence in The Netherlands.

7. US National Cancer Institute (US NCI). Incidence Rates Report - State Cancer Profiles. 2009; Available at: http://statecancerprofiles.cancer.gov/incidencerates/. Accessed 09/22, 2014.

8. Wei Y, Davis J, Bina WF. Ambient air pollution is associated with the increased incidence of breast cancer in US. Int J Environ Health Res 2012;22(1):12-21.

9. International Agency for Research on Cancer. Outdoor air pollution a leading environmental cause of cancer deaths. IARC Press Releases 2013;221. 
10. Anderson JO, Thundiyil JG, Stolbach A. Clearing the air: a review of the effects of particulate matter air pollution on human health. Journal of Medical Toxicology 2012;8(2):166-175.

11. Goldberg M. A systematic review of the relation between long-term exposure to ambient air pollution and chronic diseases. Rev Environ Health 2008;23(4):243-298.

12. Bonner MR, Han D, Nie J, Rogerson P, Vena JE, Muti P, et al. Breast cancer risk and exposure in early life to polycyclic aromatic hydrocarbons using total suspended particulates as a proxy measure. Cancer Epidemiology Biomarkers \& Prevention 2005;14(1):53-60.

13. Nie J, Beyea J, Bonner MR, Han D, Vena JE, Rogerson P, et al. Exposure to traffic emissions throughout life and risk of breast cancer: the Western New York Exposures and Breast Cancer (WEB) study. Cancer Causes \& Control 2007;18(9):947-955.

14. Crouse DL, Goldberg MS, Ross NA, Chen H, Labrèche F. Postmenopausal breast cancer is associated with exposure to traffic-related air pollution in Montreal, Canada: a case-control study. Environ Health Perspect 2010;118(11):1578.

15. Raaschou-Nielsen O, Bak H, Sørensen M, Jensen SS, Ketzel M, Hvidberg M, et al. Air pollution from traffic and risk for lung cancer in three Danish cohorts. Cancer Epidemiology Biomarkers \& Prevention 2010;19(5):1284-1291.

16. Li D, Wang M, Firozi PF, Chang P, Zhang W, Baer-Dubowska W, et al. Characterization of a major aromatic DNA adduct detected in human breast tissues. Environ Mol Mutagen 2002;39(2-3):193-200.

17. Mordukhovich I, Rossner Jr P, Terry MB, Santella RM, Zhang Y, Hibshoosh H, et al. Associations between Polycyclic Aromatic Hydrocarbon-Related Exposures and p53 Mutations in Breast Tumors. Environ Health Perspect 2010;118(4):511. 
18. Courter LA, Pereira C, Baird WM. Diesel exhaust influences carcinogenic PAH-induced genotoxicity and gene expression in human breast epithelial cells in culture. Mutation Research/Fundamental and Molecular Mechanisms of Mutagenesis 2007;625(1):72-82.

19. Johnson KC, Hu J, Mao Y. Passive and active smoking and breast cancer risk in Canada, 1994-97. Cancer Causes \& Control 2000;11(3):211-221.

20. Hystad P, Villeneuve PJ, Goldberg MS, Crouse DL, Johnson K, Canadian Cancer Registries Epidemiology Research Group. Exposure to traffic-related air pollution and the risk of developing breast cancer among women in eight Canadian provinces: A case-control study. Environ Int 2015;74:240-248.

21. Henderson SB, Beckerman B, Jerrett M, Brauer M. Application of land use regression to estimate long-term concentrations of traffic-related nitrogen oxides and fine particulate matter. Environ Sci Technol 2007;41(7):2422-2428. 


\section{Chapter 2}

\section{Literature Review}

\subsection{Epidemiology of breast cancer}

Breast cancer is the most common invasive cancer and the second-leading cause of cancer deaths among Canadian women (1). In 2014, 24,400 new cases of breast cancer and 5,000 deaths were expected in Canada, accounting for approximately 26\% of new female cancer cases and $14 \%$ of female deaths (1). There are a number of well-established risk factors for breast cancer which are explained in more detail below (see Section 2.2). These risk factors include demographic factors, reproductive factors, genetic factors, and lifestyle factors. Some occupational and environmental factors have also been observed to increase risk of breast cancer.

In Canada, the age-standardized incidence rate of breast cancer in 2014 was estimated to be 99.2 cases per 100,000 (1). The highest incidence rate by province is 101 cases per 100,000 in Ontario, Quebec, and Nova Scotia (1). The lowest are found in Prince Edward Island, New Brunswick, and Newfoundland (95, 93, and 82 cases per 100,000, respectively) (1).

As knowledge of the molecular biology of breast cancer advances, breast cancer is no longer thought of as a single disease. Breast cancer consists of a number of specific subtypes, distinguished by a woman's menopausal status when diagnosed and tumour receptor status. A few factors which are known to increase the risk of postmenopausal breast cancer have null or inverse effects on premenopausal breast cancer (eg, greater body-mass index (BMI) is protective against breast cancer in premenopausal women (relative risk $(R R)=0.58$ for women with a BMI $>31 \mathrm{~kg} / \mathrm{m}^{2}$ compared to women with a BMI $<21 \mathrm{~kg} / \mathrm{m}^{2}, 95 \%$ CI: $0.40,0.83$ ) and is a risk factor for postmenopausal women $\left(\mathrm{RR}=1.25\right.$ for women with a $\mathrm{BMI}>28 \mathrm{~kg} / \mathrm{m}^{2}$ compared to women with a BMI $<21 \mathrm{~kg} / \mathrm{m}^{2}, 95 \%$ CI: 1.02, 1.52) (2). Tumour receptors include those which respond 
to hormones, estrogen, progesterone, and HER2 (human epidermal growth factor receptor 2) (3). Depending on tumour receptor status, treatment options and benefits vary (eg, triple negative breast cancers are estrogen-receptor negative, progesterone-receptor negative, and HER2receptor negative tumours and respond poorly to hormonal and targeted therapies).

\subsection{Breast cancer risk factors}

There are a number of breast cancer risk factors which are considered potential confounders in the relationship between traffic-related air pollution and breast cancer. These include non-modifiable factors (relating to genetics, demographics, socio-economic status (SES), and the reproductive cycle) and modifiable factors (relating to health and lifestyle).

Generally, non-modifiable risk factors relate to demographics, SES, reproductive history, and family history of breast cancer. Higher age, white or Western ethnicity, higher education, and higher income are all associated with an increased risk of breast cancer (4). The highest incidence rates for breast cancer are observed in developed, Western countries such as the United States and Canada, while the lowest incidence rates are observed in Asian countries and less developed countries (4).

Factors related to the reproductive cycle are also well-established as risk factors. Early age at menarche or menstruation (1.1 to 1.9 -fold increased risk in those $\leq 11$ compared to $\geq 15$ years) $(5,6)$, late age at first full-term pregnancy ( 1 to 2 -fold increased risk in those $>30$ years compared to $<20$ years) $(5,7-10)$ nulliparity or having no children ( 1 to 2 -fold increased risk in those without children compared to those with) (4), and late age at menopause (1.1 to 1.9-fold increased risk in those $\geq 55$ compared to those $\leq 45$ years) $(5,6)$ are shown to consistently increase risk for breast cancer. Having higher parity $(0.5$-fold decreased risk for those with $\geq 5$ 
children compared to those with none) $(11,12)$ and breastfeeding (RR decreased by $4.3 \%, 95 \%$ CI: 2.9, 5.8 for every 12 months of breastfeeding) (13) are protective against breast cancer. These factors are thought to represent cumulative exposure to endogenous estrogen, a hormone produced in the body which induces cell proliferation) (14). A related procedure is oophorectomy (removal of one or both ovaries), which greatly reduces levels of endogenous estrogen. If this procedure is performed before the age of 35 (for bilateral oophorectomy) or 45 (for unilateral oophorectomy), breast cancer risk is thought to be reduced (14).

Genetic factors include family history and gene variants. A woman with more firstdegree relatives (ie, mothers, sisters, daughters) with breast cancer is at higher risk of being diagnosed with breast cancer herself $(\mathrm{R} R=2.6$ for those with a family history of breast cancer compared to those without) (7). This risk increases if the relative's breast cancer is premenopausal. Gene variants such as the BRCA1 and BRCA2 mutations are identified as strong risk factors of breast cancer. These mutations are rare in the general population, but may occur at higher rates in certain ethnic groups (eg, in Ashkenazi Jews) (4). Some low-penetrance genes variants, which induce weaker risks but are more common in the general population, have also been identified.

Modifiable risk factors include lifestyle and health factors (eg, BMI, weight, height, diet, alcohol consumption, tobacco smoking, and use of hormonal medications). BMI (body-mass index) is a summary measure of weight and height and is used in defining obesity. Obesity has differing effects on breast cancer risk with menopausal status. Obesity (BMI greater than 30 $\mathrm{kg} / \mathrm{m}^{2}$ ) and weight gain increase the risk of postmenopausal breast cancer ( $8 \%$ increase in risk per $5 \mathrm{~kg}$ increases in adult weight gain) (15-18), while having higher BMI protects against premenopausal breast cancer $\left(\mathrm{RR}=0.94,95 \% \mathrm{CI}: 0.92,0.95\right.$ per $2 \mathrm{~kg} / \mathrm{m}^{2}$ increases $)(19,20)$. 
Increased height is considered an independent factor which weakly increases risk in postmenopausal women $(\mathrm{RR}=1.07,95 \% \mathrm{CI}: 1.03,1.12$ per $5 \mathrm{~cm}$ increases in height $)(2)$. Increased height is thought to be an indicator of high energy intake during childhood (18). While increased consumption of well-done or charred meats and unsaturated fatty acids, have been observed to confer increased risks (4), there is inconsistent evidence for any one dietary factor except for alcohol consumption $(21,22)$. Risk of breast cancer increases $10 \%$ for every $10 \mathrm{~g}$ (approximately 1 drink) of alcohol consumed per day $(4,20)$. The IARC found limited evidence for the carcinogenicity of tobacco smoking for female breast cancer (23). A pooled analysis of data from 53 studies, with over 58,000 cases and 95,000 controls, found that smoking was not associated with breast cancer (24). Use of oral contraceptives (OC) and hormone replacement therapy (HRT) increases exposure to exogenous hormones and is associated with increased risk of breast cancer, especially in postmenopausal women (4). Current users of oral contraceptives have a $24 \%$ increase in risk (25). Women who are currently using OC have the highest risks of breast cancer and this risk decreases with increasing years after stopping use (25).

In addition to lifestyle-related risk factors, occupational and environmental risk factors have been associated with increased risk of breast cancer. There is consistent evidence for increased risk with exposures to ionizing radiation (22) and for women whose occupations involve shift work, which disrupts the circadian rhythm system (26). Women who worked night shifts for a long period of time had a strong increase in risk ( $R R=1.48,95 \%$ CI: 1.36, 1.61) (26). In another study, an odds ratio of 2.21 was reported for women who were employed in shift work for over 30 years compared to women who never did shift work (95\% CI: 1.14, 4.31) (27). 


\subsection{Ambient air pollution}

Air pollution is now widely accepted to be associated with mortality and various diseases, including asthma, chronic bronchitis, emphysema, cardiovascular disease, and lung cancer (28). Ambient or outdoor air pollution has recently been classified as a definite (Group 1) human carcinogen by the International Agency for Research on Cancer (IARC) (29). Ambient air pollution is composed of natural pollution (eg, volcanoes, forest fires) and anthropogenic pollution (30). The latter can be further divided into combustion sources, industrial processes, and processes related to mining and drilling (30). Air pollutants produced from combustion (burning fossil fuels for power, heat, or transportation) includes sulfur oxides, nitrogen oxides, carbon monoxide, carbon dioxide, smoke, volatile organic compounds, polycyclic aromatic hydrocarbons, and particulate matter (30). In urban areas, the main source of ambient air pollution is from motor vehicle exhaust $(30,31)$. Many components of traffic-related air pollution, such as particulate matter and specific polycyclic aromatic hydrocarbons, have also been classified as either definite or probable (Group 2A) human carcinogens (31). In urban areas, the main source of ambient air pollution is from motor vehicle exhaust $(32,33)$.

Nitrogen dioxide $\left(\mathrm{NO}_{2}\right)$ is measured routinely by environmental regulation agencies in major cities in Canada. $\mathrm{NO}_{2}$ is commonly used as a proxy measure for traffic-related air pollution and was suggested as the "best indicator among pollutants monitored of fresh combustion" (32). $\mathrm{NO}_{2}$ is considered a good indicator of traffic-related pollution trends due to its high collocational association with other pollutants (such as PAHs) (34); and this has also been found in Canada (32). It is also inexpensive and easy to measure directly with passive samplers $(35,36)$. A study in Montreal, Quebec assessed 23 air pollutants for spatial and temporal variability and although the authors concluded that there is no one single "perfect" proxy 
measure for air pollution, the nitrogen species $\left(\mathrm{NO}, \mathrm{NO}_{2}, \mathrm{NO}_{\mathrm{x}}\right)$, being strongly correlated to traffic emissions in cities and easily measured, can be considered the best available indicator of spatial variation in exposure to traffic-related air pollution (37).

\subsubsection{Challenges in measuring air pollution}

Many methods to capture variability in air pollution have been developed and used to varying degrees of success in the literature. Pollution exposure can be measured directly or indirectly at the individual-level or at the ecologic-level (38). The first published air pollution epidemiology studies characterized exposure ecologically as average annual concentrations and compared mortality rates between cities (39). However, associations found by measuring air pollution at the ecologic-level (through regulatory monitors) are subject to ecologic fallacy. Since then, it has become known that within-city variability in air pollution concentrations, especially $\mathrm{NO}_{2}$, is as great as or greater than between-city variability (39). Over the last 20 years, air pollution exposure assessment methods have been refined to estimate exposure at the individual-level (28).

Directly measuring exposure to air pollution at the individual-level will produce more accurate measurements of exposure (28). This can be done through measuring pollutant concentrations with personal monitors and global positioning systems (GPS) locators or by measuring biomarkers, which are indicators of personal exposures interacting with biological systems (28). Both methods are expensive to employ and impractical for long-term exposure and therefore are of limited use. 
Air pollution exposures can be indirectly measured through the use of exposure indicator variables (eg, traffic intensity, proximity to roads), interpolation methods (eg, kriging, inverse distance weighting), conventional dispersion methods, and land-use regression models (39). The use of exposure indicator variables as a proxy for exposure is much cruder than the other methods, but this was confirmed as a valid estimate of exposure to traffic-related air pollutants (28). Interpolation methods use stochastic modeling to estimate pollution concentrations from monitored pollutant measurements (40) while dispersion methods use emission data on stationary pollution sources (eg, home heating), mobile pollution sources (estimated by traffic indicator variables), and meteorological data (such as air temperature and wind speeds) to predict spatial and temporal concentrations. This method is relatively costly, due to data input and high GIS (geographic information systems) expertise requirements; although when used in conjunction with GIS, it is able to predict air pollution in a study area without needing passive monitoring of pollutants (40). Land-use regression (LUR) combines pollutant measurements with a number of predictor variables related to the geography of the region of interest in a stochastic model to predict exposure. Since regulatory monitor measurements alone do not capture the within-city variability, land-use regression requires additional passive monitoring (multiple daily or weekly samples) (39). This method also uses GIS which enables many unique and useful abilities in data collection and representation, location, spatial analysis, and visualization (28).

The methods used to create the LUR model used in this thesis project will be described in a later section (see Section 3.5). A 2008 study evaluated the performance of the LUR model in predicting personal exposure measurements (41). A small sample of women was given personal monitors and GPS data-loggers to estimate personal exposure to $\mathrm{NO}_{2}$. They were also assigned 
an $\mathrm{NO}_{2}$ exposure using the LUR model and their home residence. The study found that the LUR estimates were less varied than the personal measurements and demonstrated moderate correlations between the two. The LUR showed the stronger ability to predict the $\mathrm{NO}_{2}$ personal measures when compared to the other methods of exposure assessment conducted in the study (distance to nearest ambient monitor and inverse-distance weighted interpolation) (41).

\subsubsection{Determinants of traffic-related air pollution}

Concentrations of traffic-related air pollution are influenced by the type of vehicle, vehicle speeds, fuel types and quality found in the area and traffic congestion levels (42) . Environmental factors such as meteorological conditions, topography, and built environment can also affect traffic-related air pollutants. Depending on which chemical compounds are found in the atmosphere, chemical reactions occur with traffic-related air pollutants which may dilute the concentrations measured.

These factors are taken into consideration in the land-use regression model created for the region of Metro Vancouver. More detail on the land-use regression model can be found in Section 3.5.1.

\subsection{Traffic-related air pollution and breast cancer}

\subsubsection{Proposed biologic mechanisms}

This thesis project is investigating the role of traffic-related air pollution in breast cancer etiology using $\mathrm{NO}_{2}$ to estimate exposure. While some studies have shown associations between exposure to traffic-related air pollution and increased risk of breast cancer, it is still not known 
which compound or compounds in air pollution may be responsible. It is suggested that polycyclic aromatic hydrocarbons (PAHs), a chemical compound found in the ambient environment and in the human diet (43), is involved in breast cancer carcinogenesis $(33,43-45)$.

Polycyclic aromatic hydrocarbons are organic compounds which consist of systems of fused aromatic rings (46). Exposure to PAHs can be attributable to occupational, environmental, and dietary sources (47). PAHs are produced from incomplete combustion of fossil fuels (eg, gasoline or diesel in transport vehicles, coal in industrial processes) (46). They can also be found in the diet (on the surface of charred or well-done meat) and in cigarette smoke (44). They are known to be highly mutagenic, lipophilic, carcinogenic, and immunotoxic (46). Several PAHs, including benzo[a]pyrene and dibenzo[a,1]pyrene, are well-established mammary carcinogens in animal models (45).

Due to their lipophilic properties, PAHs can be stored in human milk, blood, placenta, and other fat tissues, such as the breast (48). They may reach elevated concentrations and induce carcinogenesis in the breast (33).

PAHs are genotoxic and can react with DNA to form PAH-DNA adducts. PAH-DNA adducts are formed with high exposure to PAHs and are fixed by DNA repair mechanisms; levels of PAH-DNA adducts in the blood are therefore indicators of exposure levels and DNA repair system adequacy $(44,45)$. Damage to DNA due to PAH-DNA adduct formation has been hypothesized to induce mutations in tumour suppressor genes and proto-oncogenes, increasing the risk of tumour formation and cancer risk (45).

PAHs also have estrogenic properties (ie, having similar properties as estrogen) and may mimic estrogen as an agent in cell proliferation, increasing breast cancer risk $(33,44,49)$. 


\subsubsection{Epidemiologic evidence}

Numerous epidemiologic studies have looked at the risk of cancers and other chronic diseases and traffic-related air pollution. Historically, increased risks for lung cancer $(50,51)$ and respiratory diseases $(50,52)$ have been associated with air pollution, but there is emerging evidence to suggest an association between traffic-related air pollution and increased risks for breast (33,49,53-55), brain (55), and cervical cancers (51). As traffic-related air pollution is a ubiquitous exposure, its potential carcinogenicity has a wide-reaching audience and therefore, is of public health concern.

Studies investigating the role of traffic-related air pollution have used different techniques to capture exposure. Methods assess exposure at the ecologic-level (eg, assessing study areas by their urban or rural status), at the individual-level, using personal monitors or residential histories, or at the individual-level controlling for ecology-level factors. This section will summarize the state of the epidemiologic literature by exposure assessment used.

\subsubsection{Ecologic studies}

A number of ecologic studies have shown associations between increased breast cancer incidence and measures of air pollution. In 2012, a study was conducted using ecological ambient air pollution and breast cancer incidence data in the United States (53). Associations between time trends and regional variations of air pollutant emissions and increased incidence of breast cancer were found between 1986 and 2002. Positive correlations between emissions of various air pollutants and breast cancer incidence were also observed $\left(\mathrm{NO}_{\mathrm{x}} \mathrm{r}=0.89, \mathrm{CO} \mathrm{r}=0.82\right.$, 
$\left.\mathrm{SO}_{2} \mathrm{r}=0.71, \mathrm{p}<0.001\right)(53)$. A study using breast cancer incidence trends from SEER found positive associations with monitored nitrogen oxides and traffic density in 28 counties in the United States (56). Geographic areas with higher traffic density (> 13 vehicles/mi ${ }^{2}$ ) had a significant higher risk of breast cancer incidence than areas with low traffic density $(<0.9$ vehicles/mi ${ }^{2}$ ) (56). Another ecologic study assessed breast cancer incidence by urban and rural regional status across six years in Egypt (57). Incident cases were identified from the Gharbiah population-based cancer registry from 2001 to 2006 and addresses were linked with census data to determine urban or rural status. Incidence of breast cancer was higher in urban areas compared to rural areas and this association persisted when breast cancers were stratified by hormonal receptor subtype. In a somewhat similar study conducted in the Netherlands, risk of breast cancer incidence was examined in areas of varying urbanization (58). Classification of urbanized areas was determined by address density (defined as "the number of addresses within a radius of $1 \mathrm{~km}$ of an average address in the area"). For example, very dense urbanized areas had $>2,500$ addresses $/ \mathrm{km}^{2}$ while sparsely urbanized areas had 500 to $<1,000$ addresses $/ \mathrm{km}^{2}$. Breast cancer incidence was marginally increased for each type of urbanized area compared to non-urban areas $(\mathrm{OR}=1.07,95 \% \mathrm{CI}: 1.03,1.11$, for very dense urbanization compared to non-urban areas $)(58)$. Urban areas are thought to have higher concentrations of air pollutants and occupational hazards than rural areas. With all ecologic studies, it is important to interpret results while considering ecologic fallacy. Associations using ecologic-level data may be explained by individual-level differences which these studies cannot account for, such as age at menarche, parity, or education. In the Netherlands study, authors stated that newly adopted screening programs may have confounded the relationship between breast cancer incidence and urbanization (58). Higher rates 
of screening mammography in urban regions may result in higher rates of breast cancer detection compared to non-urban regions (59).

\subsubsection{Exposure modelling}

The exposure assessment methods used in the following studies feature exposure modeling using spatiotemporal techniques, usually based in GIS. These include proximity models, dispersion models, land-use regression models, interpolation models, and hybrid models. Generally, these models are made to simulate pollutant concentrations that an individual would have been exposed to (28). More refined methods (eg, land-use regression) will produce a model which includes additional information on factors which influence pollutant concentrations. Each method makes assumptions about pollutant concentrations which are limited (eg, in proximity models, the assumption is the closer the proximity, the greater the exposure) (28). Two studies were conducted in the Erie and Niagara counties in New York State $(49,54)$. Bonner et al. employed an inverse-distance weighted interpolation technique to estimate total suspended particulates (TSP) (49). TSP measurements were taken from regulatory fixed-site monitors from 1959 to 1997 and models were created for the 1960s and each year after until 1997. The highest quartile $\left(>140 \mu \mathrm{g} / \mathrm{m}^{3}\right)$ of TSP compared to the lowest $\left(<84 \mu \mathrm{g} / \mathrm{m}^{3}\right)$ was associated with an odds ratio of 2.42 (95\% CI: 0.97, 6.09, adjusted for age, education, and parity) with suggested significance in postmenopausal women with exposures estimated for time of birth. All other associations presented (at time of birth, menarche, first birth, for both premenopausal and postmenopausal breast cancer) were null with no clear trends. While a strength of this study is its ability to estimate historical exposures in a women's past, the measurements used to model the exposure were taken from fixed-site monitors, placed in areas of high pollution which require 
monitoring (49). The interpolation method used also does not take into consideration additional factors which influences TSP dispersion patterns. Therefore the estimates for each women are potentially misclassified. There is potential for geographic selection bias in this study, as authors found that cases and controls were more likely to live closely to the study site than otherwise expected (49). In a follow-up study, Nie et al. used dispersion modeling to estimate a specific PAH, benzo[a]pyrene (BaP) for the same critical time periods (54). An odds ratio of 2.05 (95\% CI: 0.92, 4.54, adjusted for age, race, education, age at first birth, and year at interview) was observed for premenopausal women with high BaP exposure measured at time of menarche (highest quartile compared to the lowest) (54). High BaP exposure measured at time of first birth (highest quartile compared to the lowest) was associated with increased risk of postmenopausal breast cancer $(\mathrm{OR}=2.57,95 \% \mathrm{CI}: 1.16,5.69$, adjusted for age, race, education, age at first birth, and year at interview) (54). This dispersion model is a more refined method of exposure assessment than the interpolation model used in the Bonner study: it took into account various meteorological conditions, traffic flow, and seasonal differences in traffic emissions (60). The same participants were used in this study, so the same geographic selection bias may be a concern (54).

Occupational exposure to benzene and PAHs was assessed for increased risk of breast cancer in premenopausal women in Montreal (61). Job-exposure matrices and occupational histories were used to estimate exposures for cases identified from hospitals and for controls recruited randomly from the New York State Department of Motor Vehicles. Response rates were $66 \%$ and $62 \%$ for cases and controls respectively. Women who had high probabilities of being exposed to benzene and PAHs were at an increased risk of breast cancer (OR=1.95, 95\% CI: $1.14,3.33, \mathrm{OR}=2.40,95 \% \mathrm{CI}: 0.96,6.01$, respectively); however, risks related to PAH 
exposure could not be examined independently of benzene exposure so results are somewhat inconclusive. Examples of occupations with higher PAH exposure include bus, truck, and stationary engine mechanics and traffic, shipping, and receiving clerks (61).

Currently, there are only two Canadian studies which used land-use regression (LUR) to determine exposure to traffic-related air pollution and assessed risk of breast cancer: one was conducted in Montreal, Quebec (33) while the other used data from a nation-wide Canadian case-control study (62). Crouse and collaborators created land-use regression models using lifetime residential histories. Three $\mathrm{NO}_{2}$ exposures were estimated: at time of the LUR model creation (2005/6), study entry (1996/7), and approximately ten years prior (1985). This was a hospital-based case-control study of incident, invasive cases of postmenopausal breast cancer. Controls were individuals with incident cancers other than breast and were matched to cases by hospital and frequency-matched by age. Exposure to $\mathrm{NO}_{2}$ at time of study entry was associated with increased risk of postmenopausal breast cancer $\left(\mathrm{OR}=1.31\right.$ per 5 ppb increases in $\mathrm{NO}_{2}, 95 \%$ CI: 1.00, 1.71). A sensitivity analysis was conducted for subjects who resided in one residence for at least ten years and observed similar odds ratios but with wider confidence intervals (due to smaller sample sizes). Effect estimates were adjusted for hospital of diagnosis, family history of breast cancer, oophorectomy, education, ethnicity, age at menarche, age at first full-term pregnancy, breastfeeding history, oral contraceptive use, hormone replacement therapy use, BMI, exposure to tobacco smoke, respondent/proxy status, alcohol consumption, history of benign breast disease, various occupational exposures, and median household income and percentage of adults without a high school diploma at the census tract level (33).

Hystad and colleagues used similar methodology to that used in this thesis project and in the Montreal study (62). Eight of the ten provinces in Canada participated in a population-based 
case-control study and a total 1,569 breast cancer cases and 1,872 controls were recruited (63). Cases were recruited randomly from each provincial cancer agency. Controls were recruited differently in each province, either using provincial health insurance plans (PEI, Nova Scotia, Manitoba, Saskatchewan, BC), the Ministry of Finance Property Assessment database (Ontario), or random-digit dialing (Newfoundland and Alberta). Participants had to have reported at least 90\% complete residential histories from 1975 to 1994 for inclusion in this study. $\mathrm{NO}_{2}$ exposure levels were then estimated for this time period using the land-use regression model created for the entire country. Two additional exposure measures were used to characterize exposure to traffic-related air pollution involving satellite-derived observations, however, only the results from the land-use regression model will be described here. The study observed positive, nonsignificant associations $(\mathrm{OR}=1.07,95 \% \mathrm{CI}: 0.86,1.32$ and $\mathrm{OR}=1.28,95 \% \mathrm{CI}: 0.92,1.79)$ for 10 ppb increases in $\mathrm{NO}_{2}$ and post- and premenopausal breast cancer, respectively. Models were adjusted for a number of established and suspected risk factors for breast cancer, as well as age and study province: age at menarche, years of menstruation, parity, age at first full-term pregnancy, breastfeeding, bilateral oophorectomy, BMI, smoking, alcohol consumption, median household income, years of education, residential and occupational second-hand smoke exposure, meat and vegetable consumption, physical activity, mammography screening, neighbourhood-level socioeconomic deprivation, and urban living status (62).

\subsubsection{Personal exposure measurements}

A more accurate method of deriving exposure estimates is by directly measuring concentrations of pollutants. This can be done by measuring metabolites in biologic samples or by measuring pollutant concentrations using personal monitors. DNA adducts are often measured 
as a biologically effective carcinogen dose (64). They represent the metabolized internal dose that has reacted with DNA and has not yet been repaired, and are therefore a product of an individual's metabolism and repair systems as well as exposure. Several studies have examined DNA adducts as a byproduct of environmental pollutant exposure in relation to breast cancer risk. Rundle et al. conducted a hospital-based case-control study of 100 breast cancer cases and 105 controls with benign breast disease (65). PAH-DNA adducts were measured using immunohistochemical assays in cancerous and non-cancerous breast tissue from the cases and normal breast tissue from the controls. This study found a positive association for increased DNA adducts in tumour tissue compared to control tissue after controlling for potential confounders $(\mathrm{OR}=2.56,95 \% \mathrm{CI}: 1.05,6.24)(65)$. However, there may be a potential bias from using controls with benign breast disease, as the prevalence of family history of breast cancer in this population is much higher than in women without a history of benign breast disease (66). Gammon et al. conducted several studies on Long Island in New York, measuring DNA adducts from pesticide and PAH exposure (67-69). Blood levels of organochlorines did not differ between cases and controls and age-adjusted and multivariate-adjusted ORs (highest quintile compared to lowest) were weak (eg, for one organochlorine, DDT, OR=1.15, 95\% CI: 0.74 , 1.79) and not statistically significant.

In general, studies that examined organochlorine pesticide levels in adipose tissue and in blood samples in relation to breast cancer incidence have found inconclusive results (70). In the same Long Island, NY study population, breast cancer incidence was found to be associated with detectable PAH-DNA adducts in blood samples compared to non-detectable DNA adducts (ageadjusted $\mathrm{OR}=1.29,95 \% \mathrm{CI}: 1.05,1.58)(69)$. When stratified by menopausal status, postmenopausal breast cancer was not associated with detectable DNA adducts while 
premenopausal breast cancer was. The biggest limitation in using biomarkers to determine pollution exposure is that the time period of exposure estimation is never relevant to disease causation. Biomarkers are a product of too recent exposure in the case of long-term diseases, such as breast cancer $(70,71)$.

\subsection{Summary of rationale}

Traffic-related air pollution is a major concern in urban areas; exposures to air pollutants have been associated with a variety of health outcomes, including headaches, nausea, acute and chronic respiratory effects, heart disease, and several cancers. Breast cancer incidence cannot be fully explained by the current established risk factors and there exists a need for further etiological research into environmental exposures. This study uses a refined exposure assessment method known as land-use regression to estimate exposure to traffic-related air pollution to assess the risk of breast cancer incidence in Vancouver, British Columbia.

The International Agency for Research on Cancer (IARC) classified outdoor air pollution as a Group 1 or definite human carcinogen (29). Several ecologic studies have shown increased risk of breast cancer in areas of high urbanization $(57,57,58,72,73)$, and therefore, higher exposures of traffic-related air pollution, industrial pollutants, and other environmental toxins, such as pesticides. Several case-control studies have examined the relationship between trafficrelated air pollutants and breast cancer in Canada $(33,62)$, Erie and Niagara counties in New York State $(49,54)$, and in Long Island, New York (74). Additionally, there have been several studies which have measured PAH-DNA adducts, a marker of DNA damage and thought to be one of the possible carcinogenic agents within air pollution $(43,65-67,69)$. However these studies all suffer from limitations: these include using ecologic-level data and being subject to the 
ecologic fallacy, using inadequate comparison groups which may have compromised internal validity, using measurements which may not have fully captured the true geographic distribution of the exposure, and using biomarkers which may introduce misclassification, as the exposure being assigned is a measure of recent exposure rather than cumulative exposure.

This thesis project examined the association between breast cancer and traffic-related air pollution using data from a Vancouver based case control study in both pre- and postmenopausal women. $\mathrm{NO}_{2}$ was estimated using land-use regression and residential histories at time of study entry and ten years prior. This will be the third study of its kind and aims to build on the work of two prior Canadian studies $(33,62)$. 


\subsection{References}

1. Canadian Cancer Society's Advisory Committee on Cancer Statistics. Canadian Cancer Statistics 2014. Toronto, ON: Canadian Cancer Society; 2014.

2. van den Brandt PA, Spiegelman D, Yaun SS, Adami HO, Beeson L, Folsom AR, et al. Pooled analysis of prospective cohort studies on height, weight, and breast cancer risk. Am J Epidemiol 2000 Sep 15;152(6):514-527.

3. Harris L, Fritsche H, Mennel R, Norton L, Ravdin P, Taube S, et al. American Society of Clinical Oncology 2007 update of recommendations for the use of tumor markers in breast cancer. J Clin Oncol 2007 Nov 20;25(33):5287-5312.

4. Dumitrescu R, Cotarla I. Understanding breast cancer risk - where do we stand in 2005? J Cell Mol Med 2005;9(1):208-221.

5. Harris JR, Lippman ME, Veronesi U, Willett W. Breast cancer. N Engl J Med 1992;327(5):319-328.

6. Kelsey JL, Bernstein L. Epidemiology and prevention of breast cancer. Annu Rev Public Health 1996;17(1):47-67.

7. Madigan MP, Ziegler RG, Benichou J, Byrne C, Hoover RN. Proportion of breast cancer cases in the United States explained by well-established risk factors. J Natl Cancer Inst 1995 Nov 15;87(22):1681-1685.

8. Bruzzi P, Green SB, Byar DP, Brinton LA, Schairer C. Estimating the population attributable risk for multiple risk factors using case-control data. Am J Epidemiol 1985 Nov;122(5):904-914. 
9. Rockhill B, Weinberg CR, Newman B. Population attributable fraction estimation for established breast cancer risk factors: considering the issues of high prevalence and unmodifiability. Am J Epidemiol 1998 May 1;147(9):826-833.

10. Gail MH, Brinton LA, Byar DP, Corle DK, Green SB, Schairer C, et al. Projecting individualized probabilities of developing breast cancer for white females who are being examined annually. J Natl Cancer Inst 1989 Dec 20;81(24):1879-1886.

11. Layde PM, Webster LA, Baughman AL, Wingo PA, Rubin GL, Ory HW. The independent associations of parity, age at first full term pregnancy, and duration of breastfeeding with the risk of breast cancer. J Clin Epidemiol 1989;42(10):963-973.

12. Ewertz M, Duffy SW, Adami H, Kvåle G, Lund E, Meirik O, et al. Age at first birth, parity and risk of breast cancer: A meta - analysis of 8 studies from the nordic countries. International journal of cancer 1990;46(4):597-603.

13. Möller T, Olsson H, Ranstam J, Collaborative Group on Hormonal Factors in Breast Cancer. Breast cancer and breastfeeding: collaborative reanalysis of individual data from 47 epidemiological studies in 30 countries, including 50302 women with breast cancer and 96 973 women without the disease. Lancet 2002;360(9328):187-195.

14. Clemons M, Goss P. Estrogen and the risk of breast cancer. N Engl J Med 2001;344(4):276285.

15. Huang Z, Hankinson SE, Colditz GA, Stampfer MJ, Hunter DJ, Manson JE, et al. Dual effects of weight and weight gain on breast cancer risk. JAMA 1997;278(17):1407-1411.

16. Lahmann PH, Hoffmann K, Allen N, Van Gils CH, Khaw K, Tehard B, et al. Body size and breast cancer risk: findings from the European Prospective Investigation into Cancer And Nutrition (EPIC). International journal of cancer 2004;111(5):762-771. 
17. Harris RE, Namboodiri KK, Wynder EL. Breast cancer risk: effects of estrogen replacement therapy and body mass. J Natl Cancer Inst 1992 Oct 21;84(20):1575-1582.

18. Friedenreich C. Review of anthropometric factors and breast cancer risk. European Journal of Cancer Prevention 2001;10(1):15-32.

19. IARC Working Group. IARC handbook of cancer prevention, volume 6: weight control and physical activity. IARC, Lyon 2002;1.

20. Marmot M, Atinmo T, Byers T, Chen J, Hirohata T, Jackson A, et al. Food, nutrition, physical activity, and the prevention of cancer: a global perspective. 2007.

21. Michels KB, Mohllajee AP, Roset - Bahmanyar E, Beehler GP, Moysich KB. Diet and breast cancer. Cancer 2007;109(S12):2712-2749.

22. Weiderpass E, Meo M, Vainio H. Risk factors for breast cancer, including occupational exposures. Safety and health at work 2011;2(1):1-8.

23. Secretan B, Straif K, Baan R, Grosse Y, El Ghissassi F, Bouvard V, et al. A review of human carcinogens-Part E: tobacco, areca nut, alcohol, coal smoke, and salted fish. The lancet oncology 2009;10(11):1033-1034.

24. Hamajima N, Hirose K, Tajima K, Rohan T, Calle EE, Heath CW,Jr, et al. Alcohol, tobacco and breast cancer--collaborative reanalysis of individual data from 53 epidemiological studies, including 58,515 women with breast cancer and 95,067 women without the disease. Br J Cancer 2002 Nov 18;87(11):1234-1245.

25. Calle E, Heath C, MiracleMcMahill H, Coates R, Van Den Brandt P. Breast cancer and hormonal contraceptives: collaborative reanalysis of individual data on 53297 women with breast cancer and 100239 women without breast cancer from 54 epidemiological studies. Lancet 1996;347(9017):1713-1727. 
26. Megdal SP, Kroenke CH, Laden F, Pukkala E, Schernhammer ES. Night work and breast cancer risk: a systematic review and meta-analysis. Eur J Cancer 2005;41(13):2023-2032.

27. Grundy A, Richardson H, Burstyn I, Lohrisch C, SenGupta SK, Lai AS, et al. Increased risk of breast cancer associated with long-term shift work in Canada. Occup Environ Med 2013.

28. Zou B, Wilson JG, Zhan FB, Zeng Y. Air pollution exposure assessment methods utilized in epidemiological studies. Journal of Environmental Monitoring 2009;11(3):475-490.

29. International Agency for Research on Cancer. Outdoor air pollution a leading environmental cause of cancer deaths. IARC Press Releases 2013;221.

30. Hodgson E editor. A Textbook of Modern Toxicology. 4th ed. New Jersey: Wiley; 2010.

31. IARC Working Group. Polynuclear aromatic hydrocarbons part 1. Chemical, environmental and experimental data. Monograph on the evaluation of the carcinogenic risks of chemicals to humans. Int.Agency Res.Cancer 1983;32(1).

32. Brook JR, Burnett RT, Dann TF, Cakmak S, Goldberg MS, Fan X, et al. Further interpretation of the acute effect of nitrogen dioxide observed in Canadian time-series studies. Journal of Exposure Science and Environmental Epidemiology 2007;17:S36-S44.

33. Crouse DL, Goldberg MS, Ross NA, Chen H, Labrèche F. Postmenopausal breast cancer is associated with exposure to traffic-related air pollution in Montreal, Canada: a case-control study. Environ Health Perspect 2010;118(11):1578.

34. Beckerman B, Jerrett M, Brook JR, Verma DK, Arain MA, Finkelstein MM. Correlation of nitrogen dioxide with other traffic pollutants near a major expressway. Atmos Environ 2008;42(2):275-290. 
35. Henderson SB, Beckerman B, Jerrett M, Brauer M. Application of land use regression to estimate long-term concentrations of traffic-related nitrogen oxides and fine particulate matter. Environ Sci Technol 2007;41(7):2422-2428.

36. Health Effects Institute. Traffic-Related Air Pollution: A Critical Review of the Literature on Emissions, Exposure, and Health Effects. Health Effects Institute 2010;7.

37. Levy I, Mihele C, Lu G, Narayan J, Brook JR. Evaluating multipollutant exposure and urban air quality: pollutant interrelationships, neighborhood variability, and nitrogen dioxide as a proxy pollutant. Environ Health Perspect 2014 Jan;122(1):65-72.

38. Miao Q, Chen D, Buzzelli M, Aronson KJ. Environmental Equity Research: Review with Focus on Outdoor Air Pollution Research Methods and Analytic Tools. Archives of environmental \& occupational health 2014(just-accepted):00-00.

39. Hoek G, Beelen R, de Hoogh K, Vienneau D, Gulliver J, Fischer P, et al. A review of landuse regression models to assess spatial variation of outdoor air pollution. Atmos Environ 2008;42(33):7561-7578.

40. Jerrett M, Arain A, Kanaroglou P, Beckerman B, Potoglou D, Sahsuvaroglu T, et al. A review and evaluation of intraurban air pollution exposure models. Journal of Exposure Science and Environmental Epidemiology 2004;15(2):185-204.

41. Nethery E, Leckie SE, Teschke K, Brauer M. From measures to models: an evaluation of air pollution exposure assessment for epidemiological studies of pregnant women. Occup Environ Med 2008 Sep;65(9):579-586.

42. Biagtan, M, Brauer, M, Dobbin, NA, Jennejohn D, Henderson, S, Kosatsky, T, Suzuki, N, Zelazny, J. State of the Air Report. BC Lung Association's Air Quality and Health Steering Committee 2013;9. 
43. Li D, Wang M, Firozi PF, Chang P, Zhang W, Baer - Dubowska W, et al. Characterization of a major aromatic DNA adduct detected in human breast tissues. Environ Mol Mutagen 2002;39(2-3):193-200.

44. Mordukhovich I, Rossner Jr P, Terry MB, Santella RM, Zhang Y, Hibshoosh H, et al. Associations between Polycyclic Aromatic Hydrocarbon-Related Exposures and p53 Mutations in Breast Tumors. Environ Health Perspect 2010;118(4):511.

45. Courter LA, Pereira C, Baird WM. Diesel exhaust influences carcinogenic PAH-induced genotoxicity and gene expression in human breast epithelial cells in culture. Mutation Research/Fundamental and Molecular Mechanisms of Mutagenesis 2007;625(1):72-82.

46. Gurjar BR, Molina LT, Ojha CSP editors. Air Pollution: Health and Environmental Impacts. 1st ed. Florida: CRC Press; 2010.

47. El-Bayoumy K. Environmental carcinogens that may be involved in human breast cancer etiology. Chem Res Toxicol 1992;5(5):585-590.

48. Madhavan ND, Naidu KA. Polycyclic aromatic hydrocarbons in placenta, maternal blood, umbilical cord blood and milk of Indian women. Hum Exp Toxicol 1995 Jun;14(6):503-506.

49. Bonner MR, Han D, Nie J, Rogerson P, Vena JE, Muti P, et al. Breast cancer risk and exposure in early life to polycyclic aromatic hydrocarbons using total suspended particulates as a proxy measure. Cancer Epidemiology Biomarkers \& Prevention 2005;14(1):53-60.

50. Anderson JO, Thundiyil JG, Stolbach A. Clearing the air: a review of the effects of particulate matter air pollution on human health. Journal of Medical Toxicology 2012;8(2):166-175. 
51. Raaschou-Nielsen O, Bak H, Sørensen M, Jensen SS, Ketzel M, Hvidberg M, et al. Air pollution from traffic and risk for lung cancer in three Danish cohorts. Cancer Epidemiology Biomarkers \& Prevention 2010;19(5):1284-1291.

52. Goldberg M. A systematic review of the relation between long-term exposure to ambient air pollution and chronic diseases. Rev Environ Health 2008;23(4):243-298.

53. Wei Y, Davis J, Bina WF. Ambient air pollution is associated with the increased incidence of breast cancer in US. Int J Environ Health Res 2012;22(1):12-21.

54. Nie J, Beyea J, Bonner MR, Han D, Vena JE, Rogerson P, et al. Exposure to traffic emissions throughout life and risk of breast cancer: the Western New York Exposures and Breast Cancer (WEB) study. Cancer Causes \& Control 2007;18(9):947-955.

55. Raaschou-Nielsen O, Andersen ZJ, Hvidberg M, Jensen SS, Ketzel M, Sorensen M, et al. Air pollution from traffic and cancer incidence: a Danish cohort study. Environ Health 2011;10(1):67.

56. Chen F, Bina WF. Correlation of white female breast cancer incidence trends with nitrogen dioxide emission levels and motor vehicle density patterns. Breast Cancer Res Treat 2012;132(1):327-333.

57. Dey S, Soliman AS, Hablas A, Seifeldin IA, Ismail K, Ramadan M, et al. Urban-rural differences in breast cancer incidence by hormone receptor status across 6 years in Egypt. Breast Cancer Res Treat 2010;120(1):149-160.

58. Schouten LJ, Meijer H, Huveneers JA, Kiemeney LA. Urban-rural differences in cancer incidence in The Netherlands 1989-1991. Int J Epidemiol 1996 Aug;25(4):729-736.

59. Brody, JG, Kavanaugh-Lynch, MHE, Olopade, OI, Shinagawa, SM, Steingraber, S, Williams, DR. Identifying Gaps in Breast Cancer Research: Addressing Disparities and the 
Roles of the Physical and Social Environment. California Breast Cancer Research Program 2007.

60. Beyea J. Development of a traffic model for predicting airborne PAH exposures since 1960 on Long Island, New York.Report to the National Cancer Institute, and the National Institute of Environmental Health Sciences 2005.

61. Petralia SA, Vena JE, Freudenheim JL, Dosemeci M, Michalek A, Goldberg MS, et al. Risk of premenopausal breast cancer in association with occupational exposure to polycyclic aromatic hydrocarbons and benzene. Scand J Work Environ Health 1999:215-221.

62. Hystad P, Villeneuve PJ, Goldberg MS, Crouse DL, Johnson K, Canadian Cancer Registries Epidemiology Research Group. Exposure to traffic-related air pollution and the risk of developing breast cancer among women in eight Canadian provinces: A case-control study. Environ Int 2015;74:240-248.

63. Johnson KC, Hu J, Mao Y. Passive and active smoking and breast cancer risk in Canada, 1994-97. Cancer Causes \& Control 2000;11(3):211-221.

64. Gallo V, Khan A, Gonzales C, Phillips DH, Schoket B, Györffy E, et al. Validation of biomarkers for the study of environmental carcinogens: a review. Biomarkers 2008;13(5):505-534.

65. Rundle A, Tang D, Hibshoosh H, Estabrook A, Schnabel F, Cao W, et al. The relationship between genetic damage from polycyclic aromatic hydrocarbons in breast tissue and breast cancer. Carcinogenesis $2000 \mathrm{Jul} ; 21(7): 1281-1289$.

66. Rundle A, Tang D, Hibshoosh H, Schnabel F, Kelly A, Levine R, et al. Molecular epidemiologic studies of polycyclic aromatic hydrocarbon-DNA adducts and breast cancer. Environ Mol Mutagen 2002;39(2 - 3):201-207. 
67. Gammon MD, Santella RM, Neugut AI, Eng SM, Teitelbaum SL, Paykin A, et al. Environmental toxins and breast cancer on Long Island. I. Polycyclic aromatic hydrocarbon DNA adducts. Cancer Epidemiol Biomarkers Prev 2002 Aug;11(8):677-685.

68. Gammon MD, Wolff MS, Neugut AI, Eng SM, Teitelbaum SL, Britton JA, et al. Environmental toxins and breast cancer on Long Island. II. Organochlorine compound levels in blood. Cancer Epidemiol Biomarkers Prev 2002 Aug;11(8):686-697.

69. Gammon MD, Sagiv SK, Eng SM, Shantakumar S, Gaudet MM, Teitelbaum SL, et al. Polycyclic aromatic hydrocarbon-DNA adducts and breast cancer: a pooled analysis. Archives of Environmental Health: An International Journal 2004;59(12):640-649.

70. Laden F, Hunter DJ. Environmental risk factors and female breast cancer. Annu Rev Public Health 1998;19(1):101-123.

71. Godschalk RW, Van Schooten F, Bartsch H. A critical evaluation of DNA adducts as biological markers for human exposure to polycyclic aromatic compounds. Journal of biochemistry and molecular biology 2003;36(1):1-11.

72. Luginaah IN, Gorey KM, Oiamo TH, Tang KX, Holowaty EJ, Hamm C, et al. A geographical analysis of breast cancer clustering in southern Ontario: generating hypotheses on environmental influences. Int J Environ Health Res 2012;22(3):232-248.

73. Meijer H, Huveneers J, Kiemeney L. Urban-Rural Differences in Cancer Incidence in The Netherlands.

74. Shantakumar S, Gammon MD, Eng SM, Sagiv SK, Gaudet MM, Teitelbaum SL, et al. Residential environmental exposures and other characteristics associated with detectable PAH-DNA adducts in peripheral mononuclear cells in a population-based sample of adult 
females. Journal of Exposure Science and Environmental Epidemiology 2005;15(6):482490. 


\section{Chapter 3}

\section{Methods}

\subsection{Objectives}

The primary objective of this thesis was to assess the association between traffic-related air pollution exposure and breast cancer. This association was examined with air pollution exposure estimated at two time points (at study entry and ten years prior to study entry) to assess the latency in breast cancer development. This thesis also described the differences in established risk factors for breast cancer among cases and controls. Several sensitivity analyses were conducted to assess the effects of certain methodological decisions.

\subsection{Study design}

The Canadian Breast Cancer Study (CBCS) (formerly known as the Molecular Epidemiology Breast Cancer study) was a case-control study conducted in Vancouver, British Columbia and in Kingston, Ontario by Aronson et al. (1), from 2005 to 2010. It aimed to identify genetic, lifestyle, and environmental risk factors for breast cancer. To do so, a questionnaire was completed by participants (see Appendix B) and a blood or saliva sample was collected at time of study entry.

\subsection{Original study population}

Cases and controls were originally recruited for the Canadian Breast Cancer Study (formerly known as the Molecular Epidemiology Breast Cancer Study). From 2005-2010, 2,077 
women were recruited from Vancouver, British Columbia (BC) and 295 women from Kingston, Ontario. For this project, only participants from Vancouver (1,001 cases and 1,014 controls) will be analyzed. Cases were recruited from the BC Cancer Agency with in situ or invasive breast cancer. These women were 20-80 years old, had no previous cancer history (except nonmelanoma skin cancer), and lived in Vancouver or its surrounding communities (New Westminster, Richmond, and Burnaby). Controls were cancer-free individuals recruited from the Screening Mammography Program (SMP) of BC. These women were recruited from breast screening clinics in the same geographic locations as cases and had agreed to participate in research studies over the course of their routine screening. Cases and controls were frequencymatched by a five-year age group.

If consent was given, blood and/or saliva samples were taken and access to medical health records was granted. Response rates of those who consented to being contacted were 54\% for cases and 57\% for controls. Women aged 40-79 are considered eligible for the screening program in $\mathrm{BC}$, so cases under the age of 40 were excluded. Additional cases were excluded because their cancer diagnosis date occurred prior to study entry. This resulted in a final sample size of 1,001 and 1,014 eligible cases and controls, respectively.

Ethics approval for the main study was obtained from the University of British Columbia - BC Cancer Agency Ethics Board and from the Queen's University Health Sciences Research Ethics Board. Ethics approval for this student project was obtained from the Queen's University Health Sciences Research Ethics Board. 


\subsection{Data collection procedures}

The questionnaire given to participants (Appendix B) collected information on demographics, education, ethnicity, medical and reproductive history, family history of cancer, lifestyle characteristics (including smoking and alcohol habits), lifetime physical activity, cooking habits, and lifetime occupational and residential histories. Questionnaires were selfadministered or conducted by interview in English, Cantonese, Mandarin, or Punjabi.

\subsection{Exposure}

The exposure in this thesis project is nitrogen dioxide $\left(\mathrm{NO}_{2}\right)$. Average annual nitrogen dioxide exposure was estimated for each participant using their home residential history and a land-use regression model created for the region of Metro Vancouver in 2003. Nitrogen dioxide is considered a proxy for exposure to traffic-related air pollution in this study.

\subsubsection{Land-use regression}

Land-use regression (LUR) is an exposure assessment method that combines measured pollutant concentrations, characteristics of land-use, traffic, and geography in a least-squares model that estimates pollutant concentrations across the area of a specific region. The model is adapted to each region of interest which improves concentration predictions, since areas which may require additional monitoring can be identified (2). Land-use regression requires the use of geographic information systems (GIS) which can help minimize potential misclassification in exposure assignment (3). 
This thesis project used a nitrogen dioxide land-use regression model developed for the region of Metro Vancouver, created in 2003 by Henderson et al. (4). In brief, the procedure of the creation of the LUR model is outlined below.

A location-allocation model was created to identify 100 sites whose measurements would optimize variability in pollutant concentrations in Vancouver. This model used five years of regulatory data as input. A two-step algorithm was involved which first built a demand surface and then determined 100 optimal locations for $\mathrm{NO}_{2}$ sampling. An additional 16 sites were added to capture concentrations in specific areas of interest. The LUR domain covered 2,200 $\mathrm{km}^{2}$ of the Greater Metropolitan Area of Vancouver (Metro Vancouver).

To capture the seasonality of $\mathrm{NO}_{2}$ concentrations, historical regulatory $\mathrm{NO}_{2}$ data were analyzed and two 2-week sampling periods were identified as optimal. The combined means from each sampling period were within $15 \%$ of the annual average. These sampling periods ran between February 24 through March 14 and September 8 through September 26 in 2003. The measured concentrations from each sampling period were averaged to estimate the annual mean for each site. The spring and fall mean concentrations were 19.6 (SD=4.9) and 12.9 (SD=4.1) parts per billion ( $\mathrm{ppb}$ ), respectively. These concentrations were averaged to create annual estimates which were then used to create the LUR model. Annual estimates followed a normal distribution with mean 16.2 and standard deviation $5.6 \mathrm{ppb}$.

A total of 55 variables were derived to characterize each sampling site by road length, vehicle density, land use, population density, elevation, longitude, latitude, distance to nearest highway, and distance from the seashore. All were considered as possible predictors of $\mathrm{NO}_{2}$ concentrations in the final land-use regression model. Some of these predictors, such as road length and distance to highways, are coded as circular zones or "buffers" and are duplicated for 
different sized buffers. Varying buffer sizes are important since they take into consideration the air pollutant dispersion patterns (5). For example, in this land-use regression model, road length, vehicle density, land use, and population density were considered buffer variables, each with buffer radii of 100, 200, 300, 500, 750, and 1,000 meters (4).

Two models were created using two different traffic metrics: road length or vehicle density. A model-building algorithm was used to create a parsimonious final model, selecting a subset of the variables to keep in the model (4). The final model equations are in Table 3-1. The $\mathrm{R}^{2}$ values for the road length and vehicle density models were 0.56 and 0.60 , respectively. Since the vehicle density model explains more variability in the data, $\mathrm{NO}_{2}$ values were estimated using the latter model.

Table 3-1: Land-use regression model equations ${ }^{*}$ using two separate traffic metrics

\begin{tabular}{|l|c|}
\hline $\begin{array}{l}\text { Model 1 (road } \\
\text { length): }\end{array}$ & $\begin{array}{r}42.6+R D 1.100 * 10.5+R D 1.1000 * 0.275+R D 2.200 * 4.24 \\
\\
\end{array}$ \\
\hline $\begin{array}{l}\text { Model 2 (vehicle } \\
\text { density): }\end{array}$ & $+P O P .2500 * 0.074+C O M .750 * 0.116-E L E V$ \\
& $+P O P .2500 * 0.068+C O M .750 * 0.116-E L E V$ \\
& $* 0.017$ \\
\hline
\end{tabular}

* where the number after the period represents the buffer size; eg, RD1.100 = length of highways within a $100 \mathrm{~m}$ buffer. RD1=length of highways, RD2=length of major roads, DIST=distance to highways, $\mathrm{AD}=$ automobile density, $\mathrm{TD}=$ truck density, $\mathrm{POP}=$ population density, ELEV=elevation, $\mathrm{X}=$ longitude, $\mathrm{Y}=$ latitude, $\mathrm{COM}=$ commercial area, $\mathrm{RES}=$ residential area, $\mathrm{IND}=$ industrial area, and $\mathrm{OPN}=$ open area 
The vehicle density model was rendered as a map in GIS from the regression equation above (Figure 3-1). If any $\mathrm{NO}_{2}$ values produced from the regression equation were negative, they were set to zero. If any values were greater than the highest observed $\mathrm{NO}_{2}$ value measured by $20 \%$, they were reduced to an acceptable concentration. Less than $2 \%$ of values were decreased in each model.

The final land-use regression model for Vancouver was found to be relatively consistent with results from other regions, such as Montreal. The levels of $\mathrm{NO}_{2}$ observed in Vancouver and predicted by the Vancouver LUR ranged from 0 to $30 \mathrm{ppb}$ (4), while those in the Montreal study reached as high as $35.9 \mathrm{ppb}(6)$. However, the coefficients for many of the final LUR model variables created for Vancouver are comparable to other models, including the Montreal LUR (6). The Montreal LUR model explained $80 \%$ of the variation in measured $\mathrm{NO}_{2}$ in Montreal, while the Vancouver LUR explained $60 \%$ of the variation in Vancouver $\mathrm{NO}_{2}(4,6)$. However, the effect of the complex water network surrounding the study regions of both Montreal and Vancouver may not be adequately captured by the variables generated (4).

Figure 3-1 displays the 2003 LUR model for the area of Metro Vancouver. Depicted in the figure is the province of British Columbia outside of the LUR study area (in yellow), the Pacific Ocean and waterways throughout Metro Vancouver (in blue), and the LUR model in a black-white scale. The lighter regions on the map represent higher levels of $\mathrm{NO}_{2}$ while the darker regions represent areas of lower $\mathrm{NO}_{2}$ exposure. Major roads and highways (the white grid lines) can also be observed due to the increased concentrations of $\mathrm{NO}_{2}$ around these areas. The white circles are areas of commercial land-use where $\mathrm{NO}_{2}$ concentrations are very high, hypothesized to be largely due to busy intersections and idling cars. 


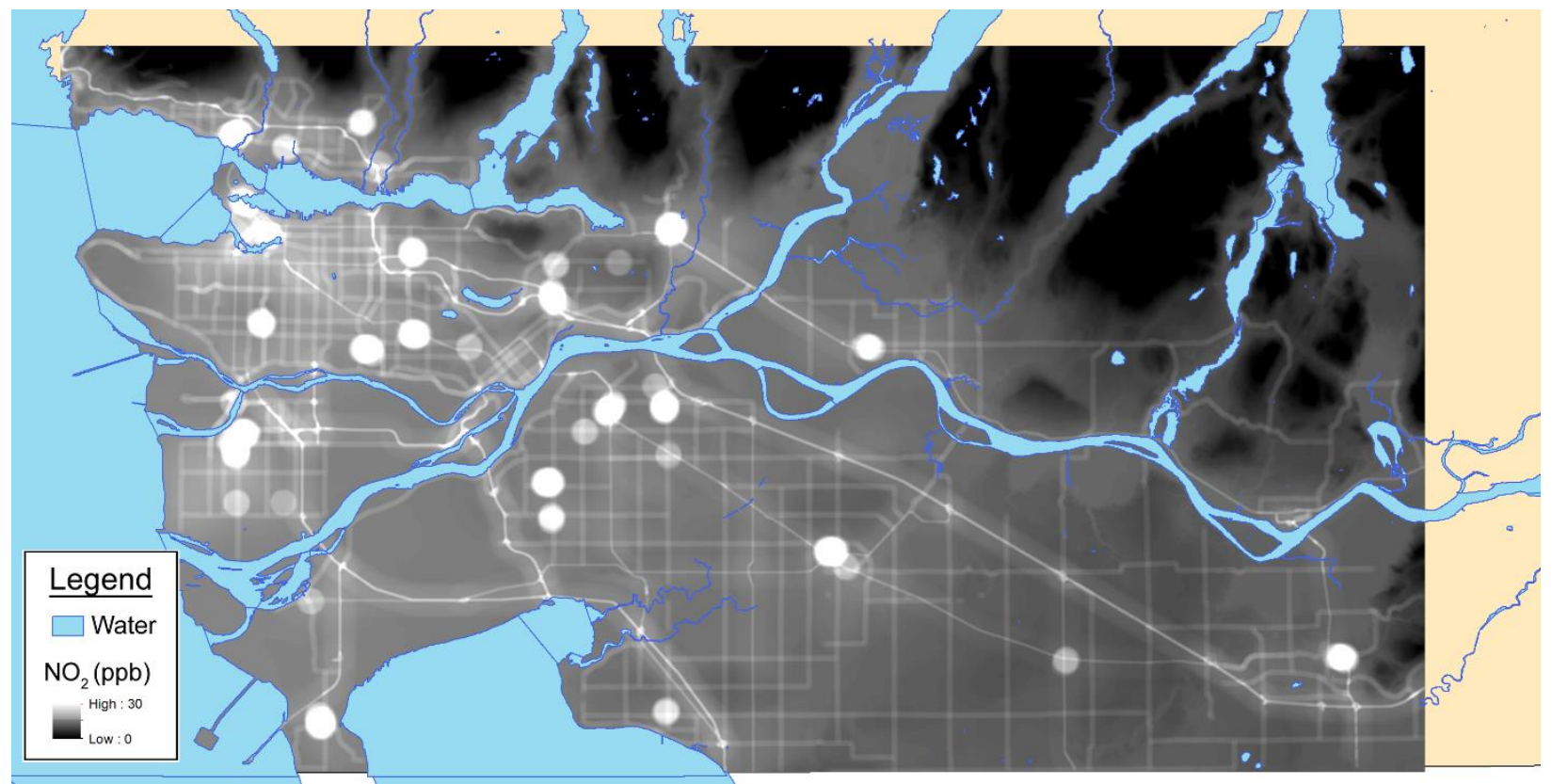

Figure 3-1: The $2003 \mathrm{NO}_{2}$ land-use regression model for Metro Vancouver

\subsubsection{Back-extrapolation of the land-use regression model}

The land-use regression model that was used in the second objective of this thesis project was back-extrapolated to estimate $\mathrm{NO}_{2}$ levels in Vancouver ten years prior to study entry. Backextrapolation of land-use regression models uses historical trends in concentrations of pollutants to estimate historical exposure to pollutants. The method used was reported in a paper by Chen et al. in 2010 (7) and is also described below.

Since women were recruited to the CBCS during 2005 to 2010, six back-extrapolated surfaces were created for the years 1995 to 2000. Regulatory fixed-site monitoring data for $\mathrm{NO}_{2}$ concentrations were obtained for the years 1995 to 2000 from the BC Air Data Archive (http://envistaweb.env.gov.bc.ca/). Only monitors which were in the study area of Metro 
Vancouver and had over $50 \%$ of daily measurements for the target year were used. The number of monitors used varied from 15 to 18 over the period of 1995 to 2000 .

Historical estimates of $\mathrm{NO}_{2}$ exposure were derived by multiplying the original 2003 LUR model with a ratio of inverse-distance weighted (IDW) interpolated surfaces of annual concentrations of $\mathrm{NO}_{2}$ measured in the target year and in 2003 (Table 3-2) (7). Inverse-distance weighted interpolation was conducted in ArcGIS using an optimal power coefficient which creates a model with the lowest root mean squared error (8). An example of this surface can be seen in Figure 3-2.

Table 3-2: Formula used for back-extrapolating in time, derived from Chen et al. (7)

\begin{tabular}{|l|l|}
\hline Method & Description of method \\
\hline $\begin{array}{l}\text { Original LUR } \\
\text { IDW }_{\text {fixed }}\end{array}$ & Original LUR $R_{2003} \times \frac{I D W_{\text {observed [NO2] for the target year }}}{I D W_{\text {observed [NO2] for } 2003}}$ \\
\hline
\end{tabular}

* LUR: land-use regression, IDW: inverse-distance weighted interpolation, $\left[\mathrm{NO}_{2}\right]$ : concentrations of $\mathrm{NO}_{2}$

\subsubsection{Geocoding residential histories}

Questionnaire data from the original Canadian Breast Cancer Study (CBCS) included information on lifetime residential histories. Participants could list up to 40 addresses and were asked for information on street address, city, postal code, country, start and termination dates in each residence, and type of residence.

Home addresses at different time points were used to estimate exposure to $\mathrm{NO}_{2}$. 


\subsubsection{Objective 1: Time of study entry}

The home address which corresponded to time of study entry for each participant was identified and geocoded using GeoPinpoint software to the region of Metro Vancouver.

Participants were excluded from this initial analysis if the address provided was missing, invalid (eg, "next door", “downtown"), or unable to be geocoded. They were also excluded if they were not able to be assigned an $\mathrm{NO}_{2}$ value (ie, resided outside of the LUR area), or if they were missing one or both of the years they moved to and from a given residence.

\subsubsection{Objective 2: Ten-year latency}

The home address which corresponded to ten years prior to study entry was identified and geocoded. Exclusions were made using the same criteria as in Objective 1. Due to the nature of IDW interpolation however, several participants who are within the LUR area fell outside the IDW area and were therefore excluded (Figure 3-2). 


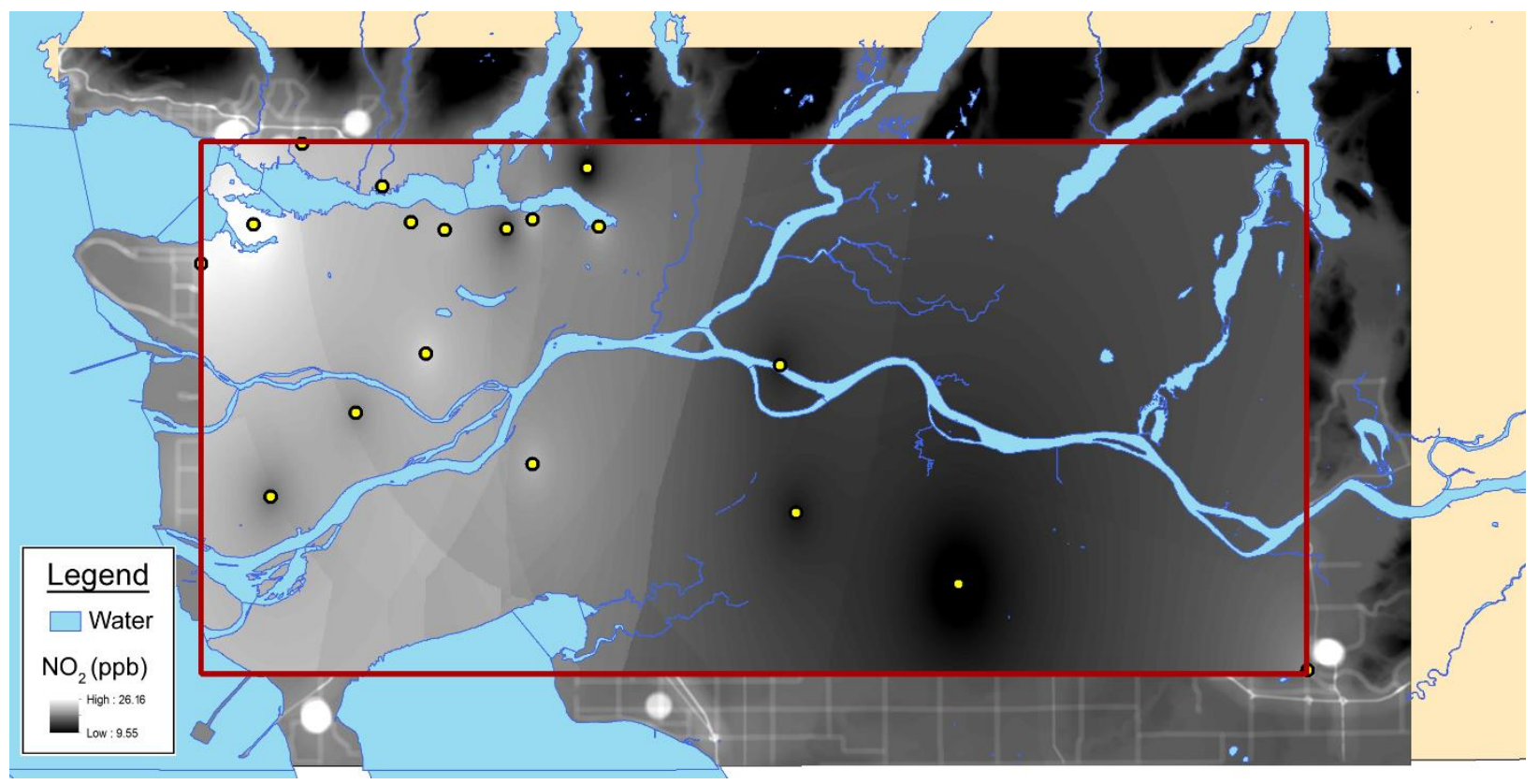

Figure 3-2: The inverse-distance weighted (IDW) interpolated surface for 1995 (marked by a red border) laid on top of the LUR model with monitors shown (yellow dots)

\subsection{4 $\mathrm{NO}_{2}$ values}

Once addresses were geocoded (ie, given an $\mathrm{x}$ - and y-coordinate) they were mapped onto the LUR model using GIS software. $\mathrm{NO}_{2}$ exposure values were extracted from the LUR model and assigned to each participant according to their geocoded address.

\subsection{Outcome}

The outcome of interest in this study is incident breast cancer. Cases were required to have an ICD code of C50 (primary breast neoplasm) that was histologically confirmed. Pathologic data was collected for all cases from the BC Cancer Registry and BC Breast Cancer Outcomes Unit. These data included tumour size, histologic type, nuclear and/or histologic 
grade, presence of lymphatic or vascular invasion, estrogen and progesterone receptor (ER, PR) status, and HER2/neu protein overexpression.

\subsection{Menopausal status}

All analyses were stratified by menopausal status in this thesis project. The etiology of breast cancer appears to vary by menopausal status. As such, rather than include menopausal status as a confounder, these study populations will be analyzed separately. Women were classified as postmenopausal if they satisfied one of the following criteria:

1) they had stopped menstruating naturally for at least one year at time of diagnosis (for cases) or study entry (for controls),

2) they had stopped menstruating naturally and were over 50 years of age,

3) they had stopped menstruating and had had a bilateral oophorectomy, or

4) they had had a bilateral oophorectomy and were over 55 years of age.

\subsection{Potential confounders}

A number of established risk factors for breast cancer were identified from the literature. Data from the Canadian Breast Cancer Study questionnaire were used to obtain information on these potential confounders, including personal characteristics, reproductive health history, medical history, family history of breast cancer, and lifestyle factors (eg, oral contraceptive drug use, alcohol consumption and smoking history). 


\subsubsection{Demographics}

Age was collected in the questionnaire as age at diagnosis for cases and age at study entry for controls. It is a continuous variable and was considered as such in all models.

There were 13 options for ethnicity: White, Chinese, South Asian, Black, Native, Arab/West Asian, Filipino, Latin American, Japanese, Korean, Southeast Asian, Other, or Mixed. Due to low numbers, some categories were collapsed, resulting in three categories: White, East Asian (Chinese, Japanese, Korean), and Other.

Educational history was ascertained through a question asking about the highest educational degree obtained. It was categorized into three levels: high school or less, trade school certificate or community college/CEGEP, university degree or higher.

Household income was categorized as no income; less than $\$ 40,000 ; \$ 40,000-\$ 59,999$; $\$ 60,000-\$ 79,999 ;$ over $\$ 80,000 ;$ and not stated.

\subsubsection{Reproductive, medical, and family history}

Information on aspects of reproductive history (age at menarche, age at first full-term pregnancy, nulliparity, number of pregnancies, duration of breastfeeding, and age at bilateral oophorectomy) was collected in the questionnaire. These were all considered established risk factors with the exception of breastfeeding and younger age ( $<35$ years) at bilateral oophorectomy which are protective factors (9). However, age at bilateral oophorectomy was not applicable in the models for premenopausal breast cancer and, it was only controlled for in the fully-adjusted model for postmenopausal women. 
Medical factors included hormonal prescriptive drug use and BMI. Oral contraceptive (OC) use and hormone replacement therapy (HRT) use were categorized into never used and used. Self-reported height and weight were used to calculate body-mass index (BMI), calculated as body weight in kilograms over height in meters squared. Self-reported heights and weights are often over- and underestimated, respectively, in women, so calculated BMI values are likely an underrepresentation of the real values (10).

Family history of breast cancer is captured in the questionnaire by asking participants to list all first-degree relatives (mother, sister, daughter) with breast cancer. This was coded as a yes/no variable (ie, "yes, I have at least one first degree relative with breast cancer”, vs. "no, I have none").

\subsubsection{Lifestyle factors}

Various lifestyle factors (alcohol consumption, smoking status, and pack-years smoked) were identified as risk factors for breast cancer and potential confounders. Participants were asked to fill out a table in the CBCS questionnaire describing the average number of alcoholic drinks (beer, wine, and spirits recorded separately) consumed per day or per week in each decade of their lives (eg, 20s, 30s, 40s, 50s). Alcohol consumption was summarized as average number of drinks consumed per week in the decade corresponding to the participant's age.

Smoking status was characterized as never smoked, former smoker, and current smoker. If a participant smoked less than 100 cigarettes in their lifetime, they were categorized as a never-smoker. Pack-years were calculated as number of packs smoked (20 cigarettes per pack) per day for the total years smoked. 


\subsubsection{Neighbourhood-level factors}

Additionally, two neighbourhood-level variables were considered as potential confounders to control for potential neighbourhood effects. A neighbourhood effect can be defined as the effect that the characteristics of a neighbourhood may have on the resident's health beyond the individual lifestyles of the residents (11) and may have an effect on health independent of the same individual-level factors(12). Neighbourhood effects can encompass service environments (eg, medical care and transportation), social environments (eg, social support, crime), and physical environments (eg, the built environment, traffic, crowding) $(11,12)$. Data from the 2006 and 1996 census were used to generate the two neighbourhood-level covariates at the census-tract level: proportion of adults over the age of 25 with at least a high school education and median household income. Neighbourhood-level median household income was categorized similarly to individual-level household income.

\subsection{Statistical analyses}

\subsubsection{Main objectives}

Descriptive statistics were conducted for the exposure variable as well as all covariates for cases and controls. To determine if variables should be categorized or kept continuous, Goodness-of-fit tests and AIC (Akaike information criterion) were used. Age at first live birth, age at bilateral oophorectomy, duration of breastfeeding, oral contraceptive and hormone replacement therapy use were categorized from continuous variables. Means and standard deviations were calculated for continuous variables and frequency tables were generated for categorical variables. T-tests and chi-square tests (Fisher's exact tests, when appropriate) were 
conducted to test the differences between cases and controls for continuous and categorical variables, respectively. Age-adjusted odds ratios for established and suspected risk factors were also calculated, adjusting for age.

Multivariable logistic regression was used to estimate the independent relationship between exposure to $\mathrm{NO}_{2}$ and risk of breast cancer. Odds ratios (OR) and 95\% confidence intervals (CI) were calculated from the logistic regression models and are considered a reasonable estimate of the relative risk. Since cases and controls were frequency-matched by age, the age variable was forced into each model. Models were created for the objectives outlined above. Using goodness-of-fit tests (Hosmer-Lemeshow and Stukel's tests), it was confirmed that the linearity assumptions of logistic regression have not been violated.

A fully-adjusted model was generated by adjusting for all covariates that were considered risk factors identified from the literature.

\subsubsection{Sensitivity analyses}

Additional sensitivity analyses were conducted:

\subsubsection{Exclusion of cases with diagnosis dates greater than two years from study entry}

In this sensitivity analysis, cases that were diagnosed two years or more before study entry were excluded. This analysis was conducted to minimize incidence-prevalence bias and to assess the relationship between $\mathrm{NO}_{2}$ exposure and breast cancer for cases with more incident diagnoses of breast cancer. 
3.9.2.2 Exclusion of participants with more than one residence in the ten years prior to study entry

This sensitivity analysis was limited to participants who had lived at the same address for greater than ten years prior to study entry. It is possible for participants to have moved outside the Vancouver region or from an area of high pollution to low pollution in the years prior to study entry. By limiting participants to those with one long-time address, misclassification due to frequent moving is minimized.

\subsubsection{Exclusion of cases who have never attended screening mammography}

Cases who had never participated in screening mammography were excluded in this sensitivity analysis. This analysis was performed to minimize the potential bias that recruiting controls from a screening mammography program might have introduced. Cases were linked to the Screening Mammography Program of $\mathrm{BC}$ with their provincial personal health numbers. Those that were not found in the program were excluded.

\subsubsection{Exclusion of participants who were not born in Canada}

Participants who were not born in Canada were excluded in this sensitivity analysis. Information was also collected on place of birth, which was considered a proxy for immigrant status. This was coded as a yes/no variable (ie, born in Canada or not). Vancouver is home to many immigrants and in $1996,35 \%$ of the population were immigrants, which rose to $37.5 \%$ in 2001 and $40 \%$ in 2006) (13). Despite the data to suggest that first generation immigrants 
typically come from a lower SES background, they are also more likely to be in better health or more health-conscious than their Canadian-born counterparts (eg, a native Canadian aged 45 years has a 55\% predicted incidence of a non-life threatening disease such as asthma compared to a recent immigrant, whose predicted incidence is less than 30\%) (14). This is known as the "healthy immigrant effect" and has been observed in Canadian and American populations $(14,15)$ which may introduce bias into effect estimates. This effect may be attributable to the fact that healthier candidates for immigration may be more financially or physically capable of immigrating or are more likely to be eligible for Canadian residency based on health screening by Canadian officials (14).

\subsubsection{Exclusion of participants who never attended screening mammography and who were not}

\section{born in Canada}

In this analysis, for the reasons outlined above in sections 3.9.2.3 and 3.9.2.4, this analysis will exclude cases who had never attended screening mammography as well as participants who were not born in Canada.

\subsubsection{Power}

Power was calculated for several logistic regression analyses in a case-control setting with no confounder adjustment, using methods described by Lubin et al. (16). Based on the results reported in the Montreal case-control study in which the largest significant effect estimate observed was 1.3 per 5 ppb increases in $\mathrm{NO}_{2},(17)$, a minimal clinically significant odds ratio of 1.3 per 5 ppb increases was selected for this project's original power calculation. The distribution 
of the exposure $\left(\mathrm{NO}_{2}\right.$ in Vancouver) was taken from the observed monitor measurements of $\mathrm{NO}_{2}$ reported in the LUR methods paper: they were normally distributed with a mean of $16.2 \mathrm{ppb}$ and a standard deviation of 5.6 ppb (4). Table 3-3 displays the power for the analyses conducted in this thesis using the sample sizes for each objective.

Table 3-3: Power calculations

\begin{tabular}{llll}
\hline Population & Cases & Controls & Power \\
\hline Objective 1 & & & \\
\hline Postmenopausal women & 617 & 579 & $99.99 \%$ \\
Premenopausal women & 345 & 366 & $98.79 \%$ \\
\hline Objective 2 & & & \\
\hline Postmenopausal women & 421 & 382 & $99.37 \%$ \\
Premenopausal women & 212 & 236 & $92.55 \%$ \\
\hline
\end{tabular}




\subsection{References}

1. Grundy A, Richardson H, Burstyn I, Lohrisch C, SenGupta SK, Lai AS, et al. Increased risk of breast cancer associated with long-term shift work in Canada. Occup Environ Med 2013 Dec;70(12):831-838.

2. Jerrett M, Arain A, Kanaroglou P, Beckerman B, Potoglou D, Sahsuvaroglu T, et al. A review and evaluation of intraurban air pollution exposure models. Journal of Exposure Science and Environmental Epidemiology 2004;15(2):185-204.

3. Zou B, Wilson JG, Zhan FB, Zeng Y. Air pollution exposure assessment methods utilized in epidemiological studies. Journal of Environmental Monitoring 2009;11(3):475-490.

4. Henderson SB, Beckerman B, Jerrett M, Brauer M. Application of land use regression to estimate long-term concentrations of traffic-related nitrogen oxides and fine particulate matter. Environ Sci Technol 2007;41(7):2422-2428.

5. Hoek G, Beelen R, de Hoogh K, Vienneau D, Gulliver J, Fischer P, et al. A review of landuse regression models to assess spatial variation of outdoor air pollution. Atmos Environ 2008;42(33):7561-7578.

6. Crouse DL, Goldberg MS, Ross NA. A prediction-based approach to modelling temporal and spatial variability of traffic-related air pollution in Montreal, Canada. Atmos Environ 2009;43(32):5075-5084.

7. Chen H, Goldberg MS, Crouse DL, Burnett RT, Jerrett M, Villeneuve PJ, et al. Backextrapolation of estimates of exposure from current land-use regression models. Atmos Environ 2010;44(35):4346-4354. 
8. ESRI. Desktop Help 10.0 - Creating maps using inverse distance weighted interpolation. 2013.

9. Weiderpass E, Meo M, Vainio H. Risk factors for breast cancer, including occupational exposures. Safety and health at work 2011;2(1):1-8.

10. Dumitrescu R, Cotarla I. Understanding breast cancer risk-where do we stand in 2005 ? J Cell Mol Med 2005;9(1):208-221.

11. Brody, JG, Kavanaugh-Lynch, MHE, Olopade, OI, Shinagawa, SM, Steingraber, S, Williams, DR. Identifying Gaps in Breast Cancer Research: Addressing Disparities and the Roles of the Physical and Social Environment. California Breast Cancer Research Program 2007.

12. O'Neill MS, Jerrett M, Kawachi I, Levy JI, Cohen AJ, Gouveia N, et al. Health, wealth, and air pollution: advancing theory and methods. Environ Health Perspect 2003 Dec;111(16):1861-1870.

13. Statistics Canada. Selected trend data for Vancouver (CMA), 1996, 2001 and 2006 censuses. 2010; Available at: http://www12.statcan.gc.ca/census-recensement/2006/dp-pd/92-596/P12.cfm?TID=0\&Lang=eng\&T=CMA\&PRCODE=59\&GEOCODE=933. Accessed 01/07, 2014.

14. McDonald JT, Kennedy S. Insights into the 'healthy immigrant effect': health status and health service use of immigrants to Canada. Soc Sci Med 2004;59(8):1613-1627.

15. Singh GK, Miller BA. Health, life expectancy, and mortality patterns among immigrant populations in the United States. Can J Public Health 2004 May-Jun;95(3):I14-21. 
16. Lubin JH, Gail MH, Ershow AG. Sample size and power for case-control studies when exposures are continuous. Stat Med 1988;7(3):363-376.

17. Crouse DL, Goldberg MS, Ross NA, Chen H, Labrèche F. Postmenopausal breast cancer is associated with exposure to traffic-related air pollution in Montreal, Canada: a case-control study. Environ Health Perspect 2010;118(11):1578. 


\section{Chapter 4}

\section{Results}

\subsection{Objective 1: Cross-sectional analysis}

The first objective for this thesis was to assess the association between $\mathrm{NO}_{2}$ exposure at study entry and risk of breast cancer. $\mathrm{NO}_{2}$ estimates were derived for each participant based on her home address at time of study entry for both cases (as a proxy for diagnosis date) and controls.

\subsubsection{Residential histories}

Cases and controls each listed an average of 5.2 residences with information at the street level; the most any participant gave was 20 residences. On average, participants lived at their last given street address for 13.9 years (13.6 years for cases and 14.1 years for controls and listed street addresses for 39.2 years (38.6 years for cases and 39.7 years for controls). There appears to be no evidence of recall bias of residential history by disease status. A breakdown of the proportion of women with 0 to 13 street addresses in the ten, 20, and 30 years before study entry are shown in Table 4-1.

A total of 2,015 participants were found to be eligible from the original Canadian Breast Cancer Study. Out of these eligible participants, the only exclusion criterion for these analyses was not having a valid street address that could be geocoded within the land-use regression (LUR) model. One-hundred and six participants (37 cases and 69 controls) were excluded due to the reasons outlined in Table 4-2, resulting in a final sample size of 1,909 participants (964 cases and 945 controls). 
Table 4-1: Number of cases and controls with varying number of street addresses in 10, 20, and 30 years before study entry in the original study population (1,001 cases and 1,014 controls)

\begin{tabular}{ccccccc}
\hline \# addresses & \multicolumn{2}{c}{$\begin{array}{c}\text { 10 years before } \\
\text { study entry }\end{array}$} & \multicolumn{2}{c}{$\begin{array}{c}\text { 20 years before } \\
\text { study entry }\end{array}$} & \multicolumn{2}{c}{$\begin{array}{c}\text { 30 years before } \\
\text { study entry }\end{array}$} \\
& Cases & Controls & Cases & Controls & Cases & Controls \\
\hline 0 & 37 & 66 & 37 & 61 & 32 & 54 \\
1 & 579 & 576 & 314 & 327 & 203 & 202 \\
2 & 245 & 260 & 291 & 264 & 243 & 212 \\
3 & 101 & 83 & 158 & 176 & 160 & 186 \\
$4-5$ & 45 & 28 & 161 & 143 & 211 & 215 \\
$6-8$ & 3 & 3 & 49 & 43 & 130 & 121 \\
$9-11$ & 0 & 0 & 0 & 2 & 28 & 23 \\
$12-13$ & 0 & 0 & 0 & 0 & 3 & 3 \\
\hline
\end{tabular}

Table 4-2: Frequency table of reasons for excluded cases and controls for objective 1

\begin{tabular}{ccl}
\hline $\begin{array}{c}\text { Cases }(\%) \\
\mathbf{N}=\mathbf{1 , 0 0 1}\end{array}$ & $\begin{array}{c}\text { Controls }(\%) \\
\mathbf{N}=\mathbf{1 , 0 1 4}\end{array}$ & Reason \\
\hline $14(1.4)$ & $6(0.6)$ & Had no residential information for the target year \\
$15(1.5)$ & $47(4.6)$ & Not enough information given in address \\
$1(0.1)$ & $2(0.2)$ & Address was outside Canada (eg, Washington) \\
$1(0.1)$ & $6(0.6)$ & Invalid addresses (eg, "4 addresses", "next door") \\
$1(0.1)$ & $4(0.4)$ & Could not confirm address for target year
\end{tabular}


$4(0.4) \quad 5(0.5) \quad$ No address existed for the target year

$1(0.1) \quad 7(0.7) \quad$ Within Canada but outside the LUR region

Total: 37 (3.7) Total: 69 (6.8)

\subsection{2 $\mathrm{NO}_{2}$}

Table 4-3 shows $\mathrm{NO}_{2}$ concentrations for premenopausal and postmenopausal women. On average, premenopausal women were exposed to more $\mathrm{NO}_{2}$ than postmenopausal women. Cases had more variable $\mathrm{NO}_{2}$ exposures (higher standard deviation) than controls. In both groups, cases and controls did not differ significantly in their average $\mathrm{NO}_{2}$ exposures ( $\mathrm{p}$-value $=0.751$ and 0.160 for postmenopausal and premenopausal women respectively).

A higher proportion of cases and controls (5.5\% of cases and $3.4 \%$ of controls) were assigned the maximum $\mathrm{NO}_{2}$ exposure of $30 \mathrm{ppb}$ (in the cross-sectional analyses) than would be expected from a normally distributed exposure (Henderson et al. observed measurements of $\mathrm{NO}_{2}$ from the monitoring stations were normally distributed with a mean of $16.2 \mathrm{ppb}$ and a standard deviation of $5.6 \mathrm{ppb}(1))$. As such, the median exposure concentration is lower than the mean for both groups of cases and controls in this project.

Table 4-3: Average $\mathrm{NO}_{2}$ levels in parts-per-billion ( $\mathrm{ppb}$ ) for post- and premenopausal women

\section{Postmenopausal women}

\begin{tabular}{llll} 
NO$_{2}(\mathbf{p p b})$ & Cases $(\mathbf{N}=617)$ & Controls $(\mathbf{N}=\mathbf{5 7 9})$ & p-value $^{\star}$ \\
\hline Mean $(\mathrm{SD})$ & $18.4(4.2)$ & $18.3(3.9)$ & 0.751
\end{tabular}


Median

17.3

17.3

\section{Premenopausal women}

\begin{tabular}{llll} 
NO2 $(\mathbf{p p b})$ & Cases $(\mathbf{N}=345)$ & Controls $(\mathbf{N}=366)$ & p-value $^{*}$ \\
\hline Mean $(\mathrm{SD})$ & $18.2(4.2)$ & $17.8(3.6)$ & 0.160 \\
Median & 17.2 & 17.3 &
\end{tabular}

${ }^{*}$ p-values were calculated for two independent sample t-tests

\subsubsection{Descriptive statistics}

Characteristics of cases and controls are described in Table 4-4 by menopausal status.

Two cases were excluded due to missing information on menopausal status. In both

postmenopausal and premenopausal women, significant differences between cases and controls

were observed for ethnicity, education, and household income. There was a higher proportion of Asians and a smaller proportion of whites among cases when compared to controls. Controls in both groups were more educated and wealthier. In terms of reproductive factors, in both groups, cases and controls did not differ in mean age at menarche or hormone replacement therapy use. In postmenopausal women only, differences between cases and controls in number of firstdegree relatives with breast cancer, age at first birth, and duration of breastfeeding were significant. Cases were more likely to have given birth before the age of 22 while controls were more likely to have never given birth. Controls also breastfed for a longer duration (pvalue $=0.05$ ). Premenopausal controls were more likely to have no children. While in both groups, there were no differences in smoking status or pack-years smoked, controls were more 
likely to have used oral contraceptives and drank more alcohol. Postmenopausal cases had a significantly higher BMI than controls; this difference was not seen in premenopausal women.

Bivariate analyses were also conducted for each of the covariates and risk of breast cancer for postmenopausal women and premenopausal women (see Appendix C, Table C-1). Similar relative risks (increased or decreased) for breast cancer were seen for each sample of women for each covariate, except in the case of BMI. Higher BMI was associated with a significant increased risk for breast cancer in the postmenopausal sample, but was associated with a decreased risk (although not significant) in the premenopausal sample. In some classic risk factors, the direction of risk was the opposite of expected (ie, instead of protective, it was a risk factor). This is the case for ethnicity, education, household income, age at menarche, OC and HRT use, and alcohol consumption. All odds ratios other than BMI followed the same direction of risk or protection for postmenopausal and premenopausal women. 
Table 4-4: Characteristics of the study population for postmenopausal and premenopausal women for all covariates by case and control status

POSTMENOPAUSAL WOMEN

PREMENOPAUSAL WOMEN

\begin{tabular}{|c|c|c|c|c|c|c|}
\hline CHARACTERISTICS & $\begin{array}{l}\text { CASES } \\
(\mathrm{n}=617) \\
{[\text { Mean }(\mathrm{SD}) / \mathrm{N}} \\
(\%)]\end{array}$ & $\begin{array}{l}\text { CONTROLS } \\
(n=579) \\
{[\text { Mean }(\mathrm{SD}) / \mathrm{N}} \\
(\%)]\end{array}$ & $\begin{array}{l}\text { p- } \\
\text { value* }\end{array}$ & $\begin{array}{l}\text { CASES } \\
(\mathrm{n}=345) \\
{[\text { Mean }(\mathrm{SD}) / \mathrm{N}} \\
(\%)]\end{array}$ & $\begin{array}{l}\text { CONTROLS } \\
(\mathrm{n}=366) \\
{[\text { Mean }(\mathrm{SD}) / \mathrm{N}} \\
(\%)]\end{array}$ & $\begin{array}{l}\text { p- } \\
\text { value* }\end{array}$ \\
\hline AGE & $62.2(8.2)$ & $62.3(8.1)$ & 0.799 & $46.4(3.9)$ & $46.8(3.8)$ & 0.224 \\
\hline \multicolumn{7}{|l|}{ ETHNICITY } \\
\hline White & $377(61.1)$ & $456(78.8)$ & $<.0001$ & $175(50.7)$ & $246(67.2)$ & $<.0001$ \\
\hline East Asian & $147(23.8)$ & $62(10.7)$ & & $119(34.5)$ & $68(18.6)$ & \\
\hline Other & $93(15.1)$ & $61(10.5)$ & & $51(14.8)$ & $52(4.2)$ & \\
\hline \multicolumn{7}{|l|}{ EDUCATION, highest level achieved } \\
\hline High school or less & $253(41.5)$ & $169(29.2)$ & $<.0001$ & $76(22.0)$ & $56(15.3)$ & 0.022 \\
\hline $\begin{array}{l}\text { Trade certificate/Completed } \\
\text { community college/CEGEP }\end{array}$ & $171(28.0)$ & $166(28.7)$ & & $110(31.9)$ & $107(29.3)$ & \\
\hline $\begin{array}{l}\text { University, graduate, or professional } \\
\text { degree }\end{array}$ & $186(30.5)$ & $243(42.0)$ & & $159(46.1)$ & $202(55.4)$ & \\
\hline Missing & 7 & 1 & & 0 & 1 & \\
\hline \multicolumn{7}{|l|}{ HOUSEHOLD INCOME } \\
\hline$<\$ 40,000$ & $121(19.9)$ & $62(10.8)$ & $<.0001$ & $61(18.3)$ & $34(9.3)$ & 0.001 \\
\hline
\end{tabular}




\begin{tabular}{|c|c|c|c|c|c|c|}
\hline \multirow[b]{2}{*}{ CHARACTERISTICS } & \multicolumn{3}{|c|}{ POSTMENOPAUSAL WOMEN } & \multicolumn{3}{|c|}{ PREMENOPAUSAL WOMEN } \\
\hline & $\begin{array}{l}\text { CASES } \\
(\mathrm{n}=617) \\
{[\text { Mean }(\mathrm{SD}) / \mathrm{N}} \\
(\%)]\end{array}$ & $\begin{array}{l}\text { CONTROLS } \\
(\mathrm{n}=579) \\
{[\text { Mean }(\mathrm{SD}) / \mathrm{N}} \\
(\%)]\end{array}$ & $\begin{array}{l}\text { p- } \\
\text { value* }^{*}\end{array}$ & $\begin{array}{l}\text { CASES } \\
(\mathrm{n}=345) \\
{[\text { Mean }(\mathrm{SD}) / \mathbf{N}} \\
(\%)]\end{array}$ & $\begin{array}{l}\text { CONTROLS } \\
(\mathrm{n}=366) \\
{[\text { Mean }(\mathrm{SD}) / \mathrm{N}} \\
(\%)]\end{array}$ & $\begin{array}{l}\text { p- } \\
\text { value* }^{*}\end{array}$ \\
\hline$\$ 40,000$ to $\$ 59,999$ & $156(25.6)$ & $136(23.7)$ & & $74(22.2)$ & $70(19.1)$ & \\
\hline$\$ 60,000$ to $\$ 79,999$ & $69(11.3)$ & $72(12.5)$ & & $37(11.1)$ & 49 (13.4) & \\
\hline$\$ 80,000$ to $\geq \$ 100,000$ & $52(8.6)$ & $49(8.5)$ & & $38(11.4)$ & $43(11.7)$ & \\
\hline No income & $105(17.2)$ & $91(15.8)$ & & $22(6.6)$ & $49(13.4)$ & \\
\hline Not stated & $106(17.4)$ & $165(28.7)$ & & $101(30.4)$ & $121(33.1)$ & \\
\hline Missing & 8 & 4 & & 12 & 0 & \\
\hline \multicolumn{7}{|c|}{ \# FIRST-DEGREE RELATIVES } \\
\hline \multicolumn{7}{|l|}{ WITH BREAST CANCER } \\
\hline None & $488(79.1)$ & $499(86.2)$ & 0.001 & $287(83.2)$ & $321(87.7)$ & 0.087 \\
\hline At least one & $129(20.9)$ & $80(13.8)$ & & $58(16.8)$ & $45(12.3)$ & \\
\hline AGE AT MENARCHE & $13.0(1.7)$ & $12.9(1.5)$ & 0.098 & $12.7(1.4)$ & $12.8(1.5)$ & 0.548 \\
\hline Missing & 5 & 5 & & 1 & 3 & \\
\hline \multicolumn{7}{|l|}{ AGE AT FIRST BIRTH } \\
\hline Never pregnant & $96(15.6)$ & $105(18.1)$ & 0.353 & $67(19.4)$ & $100(27.4)$ & 0.035 \\
\hline$<29$ & $300(48.7)$ & $261(45.1)$ & & $86(24.9)$ & 89 (24.4) & \\
\hline$\geq 29$ & $220(25.7)$ & $213(36.8)$ & & $192(55.7)$ & $176(48.2)$ & \\
\hline
\end{tabular}




\begin{tabular}{|c|c|c|c|c|c|c|}
\hline \multirow[b]{2}{*}{ CHARACTERISTICS } & \multicolumn{3}{|c|}{ POSTMENOPAUSAL WOMEN } & \multicolumn{3}{|c|}{ PREMENOPAUSAL WOMEN } \\
\hline & $\begin{array}{l}\text { CASES } \\
(\mathrm{n}=617) \\
{[\text { Mean }(\mathrm{SD}) / \mathbf{N}} \\
(\%)]\end{array}$ & $\begin{array}{l}\text { CONTROLS } \\
(\mathrm{n}=579) \\
{[\operatorname{Mean}(\mathrm{SD}) / \mathrm{N}} \\
(\%)]\end{array}$ & $\begin{array}{l}\text { p- } \\
\text { value* }\end{array}$ & $\begin{array}{l}\text { CASES } \\
(\mathrm{n}=345) \\
{[\operatorname{Mean}(\mathrm{SD}) / \mathbf{N}} \\
(\%)]\end{array}$ & $\begin{array}{l}\text { CONTROLS } \\
(\mathrm{n}=366) \\
{[\text { Mean }(\mathrm{SD}) / \mathrm{N}} \\
(\%)]\end{array}$ & $\begin{array}{l}\text { p- } \\
\text { value* }\end{array}$ \\
\hline Missing & 1 & 0 & & 0 & 1 & \\
\hline \multicolumn{7}{|l|}{ \# OF PREGNANCIES } \\
\hline 0 & $97(15.7)$ & $105(18.1)$ & 0.114 & $67(19.4)$ & $101(27.6)$ & 0.026 \\
\hline$<2$ & $84(13.6)$ & $58(10.0)$ & & $64(18.6)$ & $53(14.5)$ & \\
\hline$\geq 2$ & $436(70.7)$ & $416(71.8)$ & & $214(62.0)$ & $212(57.9)$ & \\
\hline \multicolumn{7}{|c|}{$\begin{array}{l}\text { DURATION OF BREASTFEEDING, } \\
\text { months }\end{array}$} \\
\hline$<12$ & 487 (78.9) & $426(73.6)$ & 0.050 & $255(73.9)$ & $248(67.8)$ & 0.161 \\
\hline 12 to $<24$ & $73(11.8)$ & $96(16.6)$ & & $58(16.8)$ & $81(22.1)$ & \\
\hline$\geq 24$ & $57(9.2)$ & $57(9.8)$ & & $32(9.3)$ & $37(10.1)$ & \\
\hline \multicolumn{7}{|l|}{ AGE AT BILATERAL } \\
\hline \multicolumn{7}{|l|}{ OOPHORECTOMY } \\
\hline Never had & $555(90.0)$ & $515(89.0)$ & 0.948 & N/A & N/A & N/A \\
\hline$<40$ & $10(1.6)$ & $10(1.7)$ & & N/A & N/A & \\
\hline 40 to $<50$ & $25(4.0)$ & $25(4.3)$ & & N/A & N/A & \\
\hline$\geq 50$ & $27(4.4)$ & $29(5.0)$ & & N/A & N/A & \\
\hline
\end{tabular}




\begin{tabular}{|c|c|c|c|c|c|c|}
\hline \multirow[b]{2}{*}{ CHARACTERISTICS } & \multicolumn{3}{|c|}{ POSTMENOPAUSAL WOMEN } & \multicolumn{3}{|c|}{ PREMENOPAUSAL WOMEN } \\
\hline & $\begin{array}{l}\text { CASES } \\
(\mathrm{n}=617) \\
{[\text { Mean }(\mathrm{SD}) / \mathrm{N}} \\
(\%)]\end{array}$ & $\begin{array}{l}\text { CONTROLS } \\
(n=579) \\
{[\operatorname{Mean}(\mathrm{SD}) / \mathrm{N}} \\
(\%)]\end{array}$ & $\begin{array}{l}\text { p- } \\
\text { value* }\end{array}$ & $\begin{array}{l}\text { CASES } \\
(\mathrm{n}=345) \\
{[\text { Mean }(\mathrm{SD}) / \mathrm{N}} \\
(\%)]\end{array}$ & $\begin{array}{l}\text { CONTROLS } \\
(\mathrm{n}=366) \\
{[\text { Mean }(\mathrm{SD}) / \mathrm{N}} \\
(\%)]\end{array}$ & $\begin{array}{l}\text { p- } \\
\text { value* }\end{array}$ \\
\hline Never used & $281(45.5)$ & $221(38.2)$ & 0.007 & $153(44.5)$ & $92(25.1)$ & $<.0001$ \\
\hline Used & $332(54.2)$ & $358(61.8)$ & & $191(55.5)$ & $274(74.9)$ & \\
\hline Missing & 4 & 0 & & & & \\
\hline \multicolumn{7}{|l|}{ HRT USE } \\
\hline Never used & $339(55.0)$ & $207(53.0)$ & 0.486 & $328(95.3)$ & $342(93.7)$ & 0.335 \\
\hline Used & $277(45.0)$ & $272(47.0)$ & & $16(4.7)$ & $23(6.3)$ & \\
\hline Missing & 1 & 0 & & 1 & 1 & \\
\hline \multicolumn{7}{|l|}{ AVERAGE ALCOHOL } \\
\hline $\begin{array}{l}\text { CONSUMPTION, } \\
\text { drinks/week based on age }\end{array}$ & $3.9(2.9)$ & $5.0(2.8)$ & $<.0001$ & $4.2(3.0)$ & $5.3(2.8)$ & $<.0001$ \\
\hline \multicolumn{7}{|l|}{ SMOKING STATUS } \\
\hline Non-smoker & $362(58.7)$ & $327(56.5)$ & 0.744 & $232(67.3)$ & $232(63.4)$ & 0.505 \\
\hline Former & $213(34.5)$ & $211(36.4)$ & & $96(27.8)$ & $111(30.3)$ & \\
\hline Current & $42(6.8)$ & $41(7.1)$ & & $17(4.9)$ & $23(6.3)$ & \\
\hline AVERAGE LIFETIME PACKYEARS & $7.2(14.4)$ & $6.3(12.6)$ & 0.266 & $3.4(7.7)$ & $2.9(6.5)$ & 0.371 \\
\hline Missing & 1 & 0 & & 1 & 0 & \\
\hline
\end{tabular}




\begin{tabular}{|c|c|c|c|c|c|c|}
\hline \multirow[b]{2}{*}{ CHARACTERISTICS } & \multicolumn{3}{|c|}{ POSTMENOPAUSAL WOMEN } & \multicolumn{3}{|c|}{ PREMENOPAUSAL WOMEN } \\
\hline & $\begin{array}{l}\text { CASES } \\
(\mathrm{n}=617) \\
{[\text { Mean }(\mathrm{SD}) / \mathrm{N}} \\
(\%)]\end{array}$ & $\begin{array}{l}\text { CONTROLS } \\
(\mathrm{n}=579) \\
{[\text { Mean }(\mathrm{SD}) / \mathrm{N}} \\
(\%)]\end{array}$ & $\begin{array}{l}\text { p- } \\
\text { value* }\end{array}$ & $\begin{array}{l}\text { CASES } \\
(\mathrm{n}=345) \\
{[\text { Mean }(\mathrm{SD}) / \mathbf{N}} \\
(\%)]\end{array}$ & $\begin{array}{l}\text { CONTROLS } \\
(\mathrm{n}=366) \\
{[\text { Mean }(\mathrm{SD}) / \mathrm{N}} \\
(\%)]\end{array}$ & $\begin{array}{l}\text { p- } \\
\text { value* }\end{array}$ \\
\hline BMI, $\mathrm{kg} / \mathrm{m}^{2}$ & $26.2(5.7)$ & $25.0(4.6)$ & $<.0001$ & $24.1(4.9)$ & $24.5(4.9)$ & 0.282 \\
\hline Missing & 5 & 7 & & 6 & 4 & \\
\hline
\end{tabular}




\subsubsection{Association between $\mathrm{NO}_{2}$ and breast cancer}

Two models were conducted for assessing the association between continuous $\mathrm{NO}_{2}$ (per 5 ppb increases) and breast cancer: age-adjusted and fully-adjusted (Table 4-5). Additional participants were excluded from the fully-adjusted models due to missing data for the covariates (29 cases and 21 controls in the postmenopausal sample; 21 cases and 10 controls in the premenopausal sample).

In postmenopausal women only, the fully-adjusted $\mathrm{OR}_{5 \text { ppb }}$ was 0.96 (95\% CI: $\left.0.81,1.14\right)$ while in premenopausal women, the fully-adjusted $\mathrm{OR}_{5 \mathrm{ppb}}$ was 1.17 (95\% CI: 0.93, 1.48).

Table 4-5: Age-adjusted and fully-adjusted models for association between $\mathrm{NO}_{2}$ exposure and breast cancer with odds ratios per 5 ppb increases in $\mathrm{NO}_{2}\left(\mathrm{OR}_{5 \mathrm{ppb}}\right)$

\begin{tabular}{|c|c|c|c|c|c|c|}
\hline & & & Age-adjusted & & & Fully-adjusted $^{\dagger}$ \\
\hline & Cases & Controls & $\begin{array}{l}\text { OR5ppb } \\
(95 \% \text { CI) }\end{array}$ & Cases & Controls & $\begin{array}{l}\text { OR5ppb } \\
(95 \% \text { CI })\end{array}$ \\
\hline Postmenopausal & 617 & 579 & $1.03(0.89,1.18)$ & 588 & 558 & $0.96(0.81,1.14)$ \\
\hline Premenopausal $^{\ddagger}$ & 345 & 366 & $1.15(0.95,1.39)$ & 324 & 356 & $1.17(0.93,1.48)$ \\
\hline
\end{tabular}

† adjusted for age, family history of breast cancer, education, ethnicity, age at menarche, age at first live birth, parity, breastfeeding duration, age at bilateral oophorectomy, oral contraceptive use, hormone replacement therapy use, body-mass index, smoking status, pack-years smoked, average alcohol consumption, and two neighbourhood-level variables, proportion of adults with at least high school education and median household income 
$\ddagger$ age at bilateral oophorectomy could not be adjusted for in the premenopausal sample

\subsection{Objective 2: Historical analysis}

The second objective of this thesis was to analyze the association between historical $\mathrm{NO}_{2}$ exposures from ten years before study entry and breast cancer risk. The association was assessed stratified by menopausal status, similar to the analyses in the first objective.

\subsubsection{Residential histories}

A total of 763 participants (366 cases and 396 controls) were excluded from this analysis from the original sample of 2,015 eligible participants. Due to the nature of this "historical" analysis, which was to assign $\mathrm{NO}_{2}$ estimates to participants ten years prior to study entry based on a back-extrapolation approach, many participants were excluded because of missing data (addresses or move years) or not living in the study area ten years ago. Additionally, approximately half of the excluded participants resided outside of the inverse-distance weighted (IDW) interpolated surfaces used in the back-extrapolation methods, which resulted in no available $\mathrm{NO}_{2}$ estimates. Table 4-6 outlines the different reasons why participants were excluded.

Table 4-6: Frequency table of excluded cases and controls with reasons for objective 2

\begin{tabular}{ccl}
\hline $\begin{array}{c}\text { Cases (\%) } \\
\mathbf{N}=\mathbf{1 , 0 0 1}\end{array}$ & $\begin{array}{c}\text { Controls }(\%) \\
\mathbf{N}=\mathbf{1 , 0 1 4}\end{array}$ & Reason \\
\hline $152(15.2)$ & $181(1.8)$ & Outside the IDW region
\end{tabular}



$12(1.2)$
$8(0.8)$
Not enough information given in address
$64(6.4)$
$86(8.5)$
Missing address for target year
$12(1.2)$
$18(1.8)$
Invalid addresses (eg, “4 addresses”, “next door”)
$5(0.5)$
$11(1.1)$
Could not confirm address for target year
$122(1.2)$
$92(9.1)$
Outside the LUR region

Total: 366 (36.6) Total: $396(39.0)$

\subsection{2 $\mathrm{NO}_{2}$}

Historical $\mathrm{NO}_{2}$ exposures did not differ significantly between cases and controls in the postmenopausal women sample $(\mathrm{p}$-value $=0.646)$ or in the premenopausal women sample $(\mathrm{p}$ value $=0.557$ ). Similar to the cross-sectional analysis, median values for $\mathrm{NO}_{2}$ were lower than the means (Table 4-7).

Table 4-7: $\mathrm{NO}_{2}$ means, standard deviations, and medians in parts-per-billion (ppb) for post- and premenopausal women

\section{Postmenopausal women}

\begin{tabular}{llll} 
NO2 & Cases $(\mathbf{N}=421)$ & Controls $(\mathbf{N}=382)$ & p-value* $^{*}$ \\
\hline Mean (SD) & $19.2(4.4)$ & $19.3(4.2)$ & 0.646 \\
Median & 18.1 & 18.5 &
\end{tabular}

\section{Premenopausal women}

$\mathrm{NO}_{2}$

Cases $(\mathrm{N}=212) \quad$ Controls $(\mathrm{N}=236) \quad$ p-value*




\begin{tabular}{llll}
\hline Mean (SD) & $19.1(4.7)$ & $19.4(4.4)$ & 0.557 \\
Median & 18.1 & 18.7 & \\
\hline
\end{tabular}

${ }^{*} \mathrm{p}$-values were calculated for two independent sample t-tests

\subsubsection{Association between $\mathrm{NO}_{2}$ and breast cancer}

The same models were created in this objective as with the first: age-adjusted and fullyadjusted for all a priori identified covariates. Effect estimates (odds ratios, calculated as the relative odds of having breast cancer for a $5 \mathrm{ppb}$ increase in $\mathrm{NO}_{2}$ with all else being equal) from the age-adjusted and fully-adjusted models were not statistically significant since all confidence intervals include the null value of one (Table 4-8). However, a similar pattern is observed: in postmenopausal women only, the fully-adjusted $\mathrm{OR}_{5 \text { ppb }}$ was $0.93(95 \%$ CI: $0.78,1.11)$ while in premenopausal women, the fully-adjusted $\mathrm{OR}_{5 \mathrm{ppb}}$ was stronger: 1.18 (95\% CI: 0.93, 1.49).

Table 4-8: Age-adjusted and fully-adjusted models for association between $\mathrm{NO}_{2}$ exposure and breast cancer with odds ratios per $5 \mathrm{ppb}$ increases in $\mathrm{NO}_{2}\left(\mathrm{OR}_{5 \mathrm{ppb}}\right)$

\begin{tabular}{lcccccc}
\hline & Cases & Controls & $\begin{array}{l}\text { Age-adjusted } \\
\text { OR5pb } \\
(\mathbf{9 5 \%} \text { CI) }\end{array}$ & Cases & Controls & $\begin{array}{l}\text { Fully-adjusted }^{\dagger} \\
\text { OR5ppb } \\
\mathbf{9 5 \%} \text { CI) }\end{array}$ \\
\hline Postmenopausal & 421 & 382 & $0.97(0.82,1.14)$ & 402 & 368 & $0.93(0.78,1.11)$ \\
Premenopausal $^{\ddagger}$ & 212 & 236 & $0.94(0.76,1.15)$ & 203 & 230 & $1.18(0.93,1.49)$ \\
\hline
\end{tabular}


$\dagger$ adjusted for age, family history of breast cancer, education, ethnicity, age at menarche, age at first live birth, parity, breastfeeding duration, age at bilateral oophorectomy, oral contraceptive use, hormone replacement therapy use, body-mass index, smoking status, pack-years smoked, average alcohol consumption, and two neighbourhood-level variables, proportion of adults with at least high school education and median household income $\ddagger$ age at bilateral oophorectomy could not be adjusted for in the premenopausal sample

\subsection{Sensitivity analyses}

Several sensitivity analyses were conducted to evaluate certain assumptions that were made. They are described in more detail in the following section.

\subsubsection{Exclusion of cases with diagnosis dates greater than two years from study entry}

This sensitivity analysis was restricted to cases whose diagnosis date was less than two years from study entry, to better represent incident breast cancer cases. All originally eligible controls for each main analysis (exposure estimated at the time of study entry and ten years prior using back-extrapolation) were included. The restrictions for this sensitivity analysis led to the further exclusion of 84 cases from the cross-sectional analysis and 52 cases from the backextrapolation analysis. Compared to the original analyses, effect estimates did not change substantially and all results remain null (Table 4-9). 
Table 4-9: Age-adjusted and fully-adjusted logistic regression models excluding cases with diagnosis dates greater than two years from study entry using $\mathrm{NO}_{2}$ estimates at study entry (Table 4-9A) and back-extrapolated historical $\mathrm{NO}_{2}$ estimates (Table 4-9B)

Table 4-9A: (Cross-sectional)

\begin{tabular}{|c|c|c|c|c|c|c|}
\hline & & & Age-adjusted & & & Fully-adjusted $^{+}$ \\
\hline & Cases & Controls & $\begin{array}{l}\text { OR5ppb } \\
(95 \% \text { CI })\end{array}$ & Cases & Controls & $\begin{array}{l}\text { OR5ppb } \\
(95 \% \mathrm{CI})\end{array}$ \\
\hline Postmenopausal & 570 & 579 & $1.03(0.89,1.19)$ & 543 & 558 & $0.98(0.82,1.16)$ \\
\hline Premenopausal $^{\ddagger}$ & 308 & 366 & $1.14(0.93,1.38)$ & 289 & 356 & $1.16(0.91,1.47)$ \\
\hline
\end{tabular}

Table 4-9B: (Historical)

\begin{tabular}{|c|c|c|c|c|c|c|}
\hline & & & Age-adjusted & & & Fully-adjusted $^{+}$ \\
\hline & Cases & Controls & $\begin{array}{l}\mathrm{OR}_{5 \mathrm{ppb}} \\
(95 \% \mathrm{CI})\end{array}$ & Cases & Controls & $\begin{array}{l}\text { OR5ppb } \\
(95 \% \text { CI) }\end{array}$ \\
\hline Postmenopausal & 392 & 382 & $0.99(0.84,1.16)$ & 373 & 368 & $0.95(0.79,1.14)$ \\
\hline Premenopausal $^{\ddagger}$ & 189 & 236 & $0.94(0.76,1.16)$ & 181 & 230 & $1.06(0.82,1.34)$ \\
\hline
\end{tabular}

$\dagger$ adjusted for age, family history of breast cancer, education, ethnicity, age at menarche, age at first live birth, parity, breastfeeding duration, age at bilateral oophorectomy, oral contraceptive use, hormone replacement therapy use, body-mass index, smoking status, pack-years smoked, average alcohol consumption, and two neighbourhood-level variables, proportion of adults with at least high school education and median household income 
$\ddagger$ age at bilateral oophorectomy could not be adjusted for in the premenopausal sample

\subsubsection{Exclusion of participants with more than one residence in the ten years prior to study entry}

The second sensitivity analysis conducted excluded participants who moved during a period of ten years prior to their year of study entry. This was to reduce any misclassification from having an individual with several residences being assigned an exposure from only one residence. Due to the nature of the back-extrapolation method, participants who fell outside of the IDW surfaces were excluded. For the cross-sectional analysis, 348 cases and 320 controls were excluded, while for the historical analysis, 140 cases and 129 controls were excluded. Similar to the first sensitivity analysis, effect estimates do not differ greatly from the original analyses and are not statistically significant (Table 4-10). An elevated odds ratio can be observed in the cross-sectional analysis using premenopausal women $\left(\mathrm{OR}_{5 \mathrm{ppb}}=1.21,95 \% \mathrm{CI}\right.$ : 0.84, 1.76). 
Table 4-10: Age-adjusted and fully-adjusted logistic regression models excluding participants with more than one address in the ten years from study entry using $\mathrm{NO}_{2}$ estimates at study entry (Table 4.10A) and back-extrapolated historical $\mathrm{NO}_{2}$ estimates (Table 4.10B)

Table 4.10A: (Cross-sectional)

\begin{tabular}{|c|c|c|c|c|c|c|}
\hline & & & Age-adjusted & & & Fully-adjusted $^{\dagger}$ \\
\hline & Cases & Controls & $\begin{array}{l}\text { OR5ppb } \\
(95 \% \text { CI })\end{array}$ & Cases & Controls & $\begin{array}{l}\text { OR5ppb } \\
(95 \% \text { CI) }\end{array}$ \\
\hline Postmenopausal & 449 & 447 & $1.04(0.87,1.23)$ & 428 & 434 & $0.94(0.77,1.16)$ \\
\hline Premenopausal $^{\ddagger}$ & 165 & 178 & $1.04(0.78,1.40)$ & 154 & 174 & $1.21(0.84,1.76)$ \\
\hline
\end{tabular}

Table 4.10B: (Historical)

\begin{tabular}{|c|c|c|c|c|c|c|}
\hline & & & Age-adjusted & & & Fully-adjusted $^{\dagger}$ \\
\hline & Cases & Controls & $\begin{array}{l}\text { OR5ppb } \\
(95 \% \text { CI })\end{array}$ & Cases & Controls & $\begin{array}{l}\text { OR5ppb } \\
(95 \% \text { CI) }\end{array}$ \\
\hline Postmenopausal & 363 & 340 & $1.01(0.85,1.20)$ & 345 & 329 & $1.00(0.82,1.22)$ \\
\hline Premenopausal $^{\ddagger}$ & 130 & 149 & $0.93(0.70,1.23)$ & 124 & 144 & $1.09(0.77,1.55)$ \\
\hline
\end{tabular}

† adjusted for age, family history of breast cancer, education, ethnicity, age at menarche, age at first live birth, parity, breastfeeding duration, age at bilateral oophorectomy, oral contraceptive use, hormone replacement therapy use, body-mass index, smoking status, pack-years smoked, average alcohol consumption, and two neighbourhood-level variables, proportion of adults with at least high school education and median household income $\ddagger$ age at bilateral oophorectomy could not be adjusted for in the premenopausal sample 


\subsubsection{Exclusion of cases who have never attended screening mammography}

In this third sensitivity analysis, to assess the possibility of screening-related bias due to the selection strategy of the controls, cases who had never attended screening mammography were excluded. A total of 213 cases from the cross-sectional analysis and 126 cases from the back-extrapolation analyses were excluded. The same pattern persisted in the cross-sectional analysis with a weak but not statistically significant association observed in the premenopausal sample only. This association increased moderately in the historical model, but again, was not statistically significant (Table 4-11).

Table 4-11: Age-adjusted and fully-adjusted logistic regression models excluding cases who have never attended screening mammography using $\mathrm{NO}_{2}$ estimates at study entry (Table $4.11 \mathrm{~A}$ ) and back-extrapolated historical $\mathrm{NO}_{2}$ estimates (Table 4.11B)

Table 4.11A: (Cross-sectional)

\begin{tabular}{lccllll}
\hline & Cases & Controls & $\begin{array}{l}\text { Age-adjusted } \\
\text { OR5ppb } \\
(\mathbf{9 5 \%} \text { CI) }\end{array}$ & Cases & Controls & $\begin{array}{l}\text { Fully-adjusted }^{+} \\
\text {OR5ppb } \\
(\mathbf{9 5 \%} \text { CI) }\end{array}$ \\
\hline Postmenopausal & 534 & 579 & $1.03(0.89,1.19)$ & 508 & 558 & $0.99(0.83,1.18)$ \\
Premenopausal $^{\ddagger}$ & 215 & 366 & $1.10(0.89,1.37)$ & 202 & 356 & $1.12(0.86,1.47)$ \\
\hline
\end{tabular}




\begin{tabular}{|c|c|c|c|c|c|c|}
\hline & & & Age-adjusted & & & Fully-adjusted \\
\hline & Cases & Controls & $\begin{array}{l}\text { OR5ppb } \\
(95 \% \mathrm{CI})\end{array}$ & Cases & Controls & $\begin{array}{l}\text { OR5ppb } \\
(95 \% \text { CI) }\end{array}$ \\
\hline Postmenopausal & 377 & 382 & $0.99(0.84,1.16)$ & 359 & 368 & $0.98(0.81,1.18)$ \\
\hline Premenopausal $^{\ddagger}$ & 130 & 236 & $0.99(0.79,1.25)$ & 124 & 230 & $1.20(0.91,1.59)$ \\
\hline
\end{tabular}

$\dagger$ adjusted for age, family history of breast cancer, education, ethnicity, age at menarche, age at first live birth, parity, breastfeeding duration, age at bilateral oophorectomy, oral contraceptive use, hormone replacement therapy use, body-mass index, smoking status, pack-years smoked, average alcohol consumption, and two neighbourhood-level variables, proportion of adults with at least high school education and median household income ¥ age at bilateral oophorectomy could not be adjusted for in the premenopausal sample

\subsubsection{Exclusion of participants who were not born in Canada}

Participants who were not born in Canada were excluded in this sensitivity analysis to assess for a possible healthy immigrant effect (2,3). For the first analysis, 539 cases and 394 controls were excluded. For the second analysis, 342 cases and 242 controls were excluded. The pattern of results was similar to previous models with a weak but not statistically significant association observed predominantly in the premenopausal analyses. Since many participants were excluded in this analysis, confidence intervals are wider than in previous analyses and all include the null value of one (Table 4-12). 
Table 4-12: Age-adjusted and fully-adjusted logistic regression models excluding participants not born in Canada using $\mathrm{NO}_{2}$ estimates at study entry (Table 4.12A) and back-extrapolated historical $\mathrm{NO}_{2}$ estimates (Table 4.12B)

Table 4.12A: (Cross-sectional)

\begin{tabular}{|c|c|c|c|c|c|c|}
\hline & & & Age-adjusted & & & Fully-adjusted $^{\dagger}$ \\
\hline & Cases & Controls & $\begin{array}{l}\text { OR5ppb } \\
(95 \% \text { CI) }\end{array}$ & Cases & Controls & $\begin{array}{l}\text { OR5ppb } \\
(95 \% \text { CI) }\end{array}$ \\
\hline Postmenopausal & 279 & 331 & $1.01(0.82,1.25)$ & 267 & 321 & $0.95(0.73,1.22)$ \\
\hline Premenopausal $^{\ddagger}$ & 144 & 220 & $1.13(0.82,1.56)$ & 135 & 216 & $1.23(0.82,1.86)$ \\
\hline
\end{tabular}

Table 4.12B: (Historical)

\begin{tabular}{|c|c|c|c|c|c|c|}
\hline & Cases & Controls & $\begin{array}{l}\text { Age-adjusted } \\
\text { OR5ppb }(95 \% \\
\text { CI) }\end{array}$ & Cases & Controls & $\begin{array}{l}\text { Fully-adjusted } \\
\text { OR5ppb }(95 \% \\
\text { CI) }\end{array}$ \\
\hline Postmenopausal & 194 & 214 & $0.98(0.77,1.23)$ & 188 & 208 & $1.05(0.81,1.38)$ \\
\hline Premenopausal $^{\ddagger}$ & 97 & 162 & $0.94(0.70,1.25)$ & 93 & 158 & $1.08(0.76,1.52)$ \\
\hline
\end{tabular}

$\dagger$ adjusted for age, family history of breast cancer, education, ethnicity, age at menarche, age at first live birth, parity, breastfeeding duration, age at bilateral oophorectomy, oral contraceptive use, hormone replacement therapy use, body-mass index, smoking status, pack-years smoked, average alcohol consumption, and two neighbourhood-level variables, proportion of adults with at least high school education and median household income 
$\ddagger$ age at bilateral oophorectomy could not be adjusted for in the premenopausal sample

\subsubsection{Exclusion of participants who have never attended screening mammography and who were not born in Canada}

Cases who had never attended screening mammography were excluded to assess the possibility of screening-related bias due to the selection strategy of the controls. In addition, participants who were not born in Canada were excluded in this sensitivity analysis to assess for a possible healthy immigrant effect $(2,3)$. While all confidence intervals include the null value of one, effect estimates seen in this analysis are stronger than observed in previous analyses, particularly in the premenopausal sample (Table 4-13).

Table 4-13: Age-adjusted and fully-adjusted logistic regression models excluding participants who have never attended screening mammography and who were not born in Canada using $\mathrm{NO}_{2}$ estimates at study entry (Table 4.13A) and back-extrapolated historical $\mathrm{NO}_{2}$ estimates (Table 4.13B)

Table 4.13A: (Cross-sectional)

\begin{tabular}{|c|c|c|c|c|c|c|}
\hline & & & Age-adjusted & & & Fully-adjusted $^{\dagger}$ \\
\hline & Cases & Controls & $\begin{array}{l}\text { OR5ppb } \\
(95 \% \text { CI) }\end{array}$ & Cases & Controls & $\begin{array}{l}\text { OR5ppb } \\
(95 \% \mathrm{CI})\end{array}$ \\
\hline Postmenopausal & 252 & 331 & $1.04(0.84,1.28)$ & 239 & 321 & $0.99(0.77,1.29)$ \\
\hline
\end{tabular}


Premenopausal $^{\ddagger} 101 \quad 220 \quad 1.08(0.74,1.58) \quad 94 \quad 215 \quad 1.22(0.76,1.94)$

Table 4.13B: (Historical)

\begin{tabular}{|c|c|c|c|c|c|c|}
\hline & \multicolumn{5}{|c|}{ Age-adjusted } & \multirow{3}{*}{$\begin{array}{l}\text { Fully-adjusted }{ }^{\dagger} \\
\text { OR5ppb }(95 \% \\
\text { CI) }\end{array}$} \\
\hline & Cases & Controls & OR $5 p p b(95 \%$ & Cases & Controls & \\
\hline & & & CI) & & & \\
\hline Postmenopausal & 176 & 214 & $1.02(0.80,1.29)$ & 169 & 208 & $1.15(0.87,1.51)$ \\
\hline Premenopausal $^{\ddagger}$ & 64 & 162 & $1.07(0.77,1.48)$ & 61 & 158 & $1.37(0.92,2.05)$ \\
\hline
\end{tabular}

$\dagger$ adjusted for age, family history of breast cancer, education, ethnicity, age at menarche, age at

first live birth, parity, breastfeeding duration, age at bilateral oophorectomy, oral contraceptive use, hormone replacement therapy use, body-mass index, smoking status, pack-years smoked, average alcohol consumption, and two neighbourhood-level variables, proportion of adults with at least high school education and median household income $\ddagger$ age at bilateral oophorectomy could not be adjusted for in the premenopausal sample 


\subsection{References}

1. Henderson SB, Beckerman B, Jerrett M, Brauer M. Application of land use regression to estimate long-term concentrations of traffic-related nitrogen oxides and fine particulate matter. Environ Sci Technol 2007;41(7):2422-2428.

2. McDonald JT, Kennedy S. Insights into the 'healthy immigrant effect': health status and health service use of immigrants to Canada. Soc Sci Med 2004;59(8):1613-1627.

3. Singh GK, Miller BA. Health, life expectancy, and mortality patterns among immigrant populations in the United States. Can J Public Health 2004 May-Jun;95(3):I14-21. 


\section{Chapter 5}

\section{Discussion}

\subsection{Summary of main findings}

This study found limited evidence of an association between exposure to outdoor concentrations of $\mathrm{NO}_{2}$ and incidence of breast cancer in a case-control study conducted between 2005 and 2010 in Vancouver, BC. Two exposure metrics were used to determine concentrations of $\mathrm{NO}_{2}$ : cross-sectional concentrations taken at time of entry into the case-control study (between the years 2005 and 2010), and historical concentrations taken ten years prior to study entry (between 1995 and 2000).

Specifically, the analysis at study entry included 964 cases and 945 controls and used local $\mathrm{NO}_{2}$ estimates from a 2003 land-use regression (LUR) model developed for the city of Vancouver and its surrounding areas. The average concentration of $\mathrm{NO}_{2}$ was approximately 18 ppb for both cases and controls, but was not normally distributed, likely due to the truncation of the LUR model at a maximum exposure of $30 \mathrm{ppb}$. The original Vancouver LUR methods paper reported measurements of $\mathrm{NO}_{2}$ from the passive monitoring stations to be normally distributed (1), but the estimates for participants in this thesis project were not. No association between $\mathrm{NO}_{2}$ exposure (per 5 ppb increases) and risk of breast cancer incidence was observed in the postmenopausal sample of women $\left(\mathrm{OR}_{5 \mathrm{ppb}}=0.96,95 \% \mathrm{CI}: 0.81,1.14\right.$ for the cross-sectional analysis and $\mathrm{OR}_{5 \mathrm{ppb}}=0.93,95 \% \mathrm{CI}: 0.78,1.11$ for the historical analysis). A consistent positive association between $\mathrm{NO}_{2}$ exposure and incidence of breast cancer in premenopausal women was observed, although the odds ratios never reached statistical significance at the conventional alpha level of $0.05\left(\mathrm{OR}_{5 \mathrm{ppb}}=1.17,95 \% \mathrm{CI}\right.$ : $0.93,1.48$ for the cross-sectional analysis and $\mathrm{OR}_{5 \mathrm{ppb}}=1.18$, 
95\% CI: $0.93,1.49$ for the historical analysis). When the analysis was restricted to only

premenopausal cases and controls that had attended mammography screening, the magnitude of the association between historical exposure to $\mathrm{NO}_{2}$ and incidence of breast cancer increased, although the confidence interval still included one $\left(\mathrm{OR}_{5 \mathrm{ppb}}=1.20 ; 95 \%\right.$ CI $\left.0.91,1.59\right)$.

The remainder of this chapter will compare the results from this project with the current literature on traffic-related air pollution and incidence of breast cancer. The methodological strengths and limitations of this research are presented including suggestions for future research directions.

\subsection{Comparison of findings with relevant literature}

To date, there have been only a handful of studies evaluating the association between traffic-related air pollution and breast cancer (2-7). Of these, two used traffic exposure metrics $(3,4)$, one measured total suspended particulates $(5)$, and three used measurements of $\mathrm{NO}_{\mathrm{x}}(2,6,7)$ to estimate exposure to traffic-related air pollution. Results from some of these studies are provocative, suggesting weak to modest associations between different markers of air pollution and incidence of breast cancer, although the majority of observed effect estimates have not been statistically significant at the alpha level of 0.05 . There also appears to be qualitative heterogeneity by menopausal status in the literature and results seem to vary according to study design and exposure assessment strategy.

Similar to the results observed in this study, a recent publication by Hystad and colleagues observed an increased incidence in premenopausal breast cancer $(\mathrm{OR}=1.28,95 \% \mathrm{CI}$ : 0.92, 1.79 , per $10 \mathrm{ppb}$ increases in $\mathrm{NO}_{2}$ ) among women with an elevated exposure to $\mathrm{NO}_{2}$ (based 
on a 20 year average) but a weak to negligible association between increased exposure to $\mathrm{NO}_{2}$ and incidence of postmenopausal breast cancer $(\mathrm{OR}=1.07,95 \% \mathrm{CI}: 0.86,1.32$, per $10 \mathrm{ppb}$ increases in $\mathrm{NO}_{2}$ ) (6). Like this project, Hystad et al. also used data from a case-control study and estimated $\mathrm{NO}_{2}$ using a LUR approach. In contrast, the only other study in Canada to use a LUR approach to estimate $\mathrm{NO}_{2}$ exposure, conducted by Crouse et al., observed a much stronger association between increased $\mathrm{NO}_{2}$ exposure (per 5 ppb increases) and risk of postmenopausal breast cancer $\left(\mathrm{OR}_{5 \mathrm{ppb}}=1.31 ; 95 \% \mathrm{CI}: 1.00,1.71\right)(7)$. Crouse and collaborators used city-level data from Montreal for $\mathrm{NO}_{2}$ exposure assignment, finer resolution than the national-level data used in the Hystad study, and this difference in precision in exposure assessment may explain the difference in their results. However, it does not explain the difference observed between the Montreal study and this thesis project that also used city-level data but did not observe an association between $\mathrm{NO}_{2}$ and risk of breast cancer among postmenopausal women.

A few other studies in predominantly postmenopausal populations, albeit using different markers of exposure to traffic-related air pollution, have also reported elevated risk of breast cancer with increased exposure to air pollution. In these studies, the direction of the effect has been consistently positive $(2,3,5)$, although only one of the three studies $(5)$ observed a statistically significant result. Furthermore, the study by Lewis-Michl also observed an inverse association between traffic density and breast cancer among postmenopausal women in Suffolk County $(\mathrm{OR}=0.89,95 \% \mathrm{CI}: 0.40,1.99)$ in contrast to those living in Nassau County $(\mathrm{OR}=1.29$, 95\% CI: $0.77,2.15)(3)$. The authors hypothesized that the higher probability of greater exposure in Nassau country than in Suffolk and the difference in case participation rates in each county may be reasons why this difference was observed. 
There are several explanations for the discrepancy in effect estimates for postmenopausal women in this project and those reported elsewhere in the literature. The Montreal study (7) used two methods to back-extrapolate the $\mathrm{NO}_{2}$ LUR models: the first method, also used in this thesis, used fixed-site monitoring station $\mathrm{NO}_{2}$ measurements to create inverse-distance weighted interpolation maps for the target years and year of LUR creation, while the second method used predicted $\mathrm{NO}_{2}$ values from the 2005 LUR model at the locations of the fixed-site monitoring stations (8). Both methods produced very similar estimates of effects (7) for the time periods of interest (time of study entry: 1996; time of LUR development: 2006; and historical exposure ten years prior: 1986), although only the second back-extrapolation procedure for the 1996 (crosssectional) model produced results that were statistically significant. In this thesis project, backextrapolation of $\mathrm{NO}_{2}$ estimates based on an LUR model developed in 2003 did not change the magnitude of the estimated association except perhaps in two analyses restricted to 1) prior participation in a screening mammography program and 2) participants born in Canada. In both of these sub-analyses, increased exposure to $\mathrm{NO}_{2}$ was associated with an elevated risk of breast cancer among premenopausal women. When restricted to postmenopausal participants born in Canada, the OR $\mathrm{ORpb}_{5 \mathrm{pb}}$ of 1.08 (95\% CI: 0.76, 1.52) compared most closely to the results from Hystad et al. ( $\mathrm{OR}_{10 \mathrm{ppb}}=1.07,95 \%$ CI: $\left.0.86,1.32\right)(6)$. It is possible that while an effect may exist between $\mathrm{NO}_{2}$ and postmenopausal breast cancer, the study in Vancouver did not have enough statistical power to detect this association. For example, if the true relationship between $\mathrm{NO}_{2}$ and breast cancer was non-linear and associations are only apparent after a certain threshold, the city of Vancouver may not have the correct prevalence of high exposures to $\mathrm{NO}_{2}$ to detect them. Importantly, $\mathrm{NO}_{2}$ estimates from the LUR model were restricted to a maximum threshold of 30 ppb in the Vancouver LUR model. It cannot be explained why this might have differentially 
affected the results by menopausal status. In addition, although this study initially reported high power to detect an association of 1.3 under the assumption of a normally distributed exposure (see Section 3.9), this assumption may not be valid and the effects of a non-normally distributed exposure on the power calculated is not known.

Some study limitations and different methodological approaches may account for observed differences between studies. One limitation is the fundamentally different air quality between Montreal, Vancouver, and other major Canadian cities which influences $\mathrm{NO}_{2}$ variability and exposure levels. For example, Montreal has a larger population, almost double that of Vancouver in 1996 (3.3 million compared to 1.8 million in Vancouver) $(9,10)$. Population size and density are directly related to the number of automobiles and therefore levels of trafficrelated air pollution in urban areas $(11,12)$. While average $\mathrm{NO}_{2}$ levels were comparable in Montreal and Vancouver in 2011 ( 11-12 ppb), levels of particulate matter, another good indicator of traffic-related air pollution and air quality, were twice as high in Montreal than in Vancouver (13). Montreal is also generally considered to have worse air quality and greater air pollution than Vancouver and other Canadian cities such as Toronto when using air quality indicators such as ozone and particulate matter (14). The lack of variability in $\mathrm{NO}_{2}$ levels in Vancouver may have limited the ability of this study to detect potential effects on risk of breast cancer if a non-linear relationship exists between $\mathrm{NO}_{2}$ and breast cancer.

The LUR models for both Vancouver and Montreal are also fundamentally different in their creations, although both used similar covariates and modelling approaches. The Vancouver LUR model explained less variability in $\mathrm{NO}_{2}$ compared to the Montreal LUR model (60\% vs. $73 \%)(6,7)$. Another limitation may be the selection strategy of the controls: in the Vancouverbased case-control study for this project, the controls came from the mammography screening 
program in Vancouver, while the controls in the Montreal case-control study were recruited from hospitals and were patients with cancers other than breast and bladder cancers (7). Importantly, only postmenopausal women were included in the Crouse study. Controls used in the Hystad national case-control study among women in eight provinces were population-based and women were recruited through a variety of methods such as random digit dialing and random sampling from health insurance plans (6). An important criticism of the Vancouver case-control design is the selection of controls from a screening program: women who attend screening programs are typically healthier, better educated, and wealthier than those who do not participate in screening programs, and this is apparent in the descriptive data reported here. These factors may also influence choice of residential neighborhood and in turn, exposure to traffic-related $\mathrm{NO}_{2}$. This potential selection bias was addressed in a sensitivity analysis that restricted the analysis to those cases and controls who had participated in screening programs in the past, leading to a larger odds ratio comparable to that observed by Hystad et al. in women with premenopausal breast cancer. However, this analysis did not change the interpretation of the effect estimates for postmenopausal women, perhaps because most postmenopausal cases had previously participated in screening mammography programs ( $87 \%$ had previously participated in screening).

Despite adjusting for potential confounding by important risk factors for breast cancer including SES, education, and ethnicity, residual confounding may still exist, especially related to immigrant status, since those women not born in Canada are under-represented in the case group (48\% of the cases were Canadian-born vs. 65\% of the population in Vancouver in 1996, according to the national census) (9). Montreal has a larger population, almost twice as large compared to Vancouver in 1996 (3.3 million compared to 1.8 million in Vancouver) $(9,10)$. 
Population size and density is directly related to the number of automobiles and therefore levels of traffic-related air pollution in urban areas $(11,12)$. In addition, Vancouver is home to nearly twice as many non-English and non-French speaking people than Montreal (33\% compared to $18 \%$ of the population whose mother tongue was not French or English in 1996), twice as many immigrants (35\% compared to $18 \%$ of the population in 1996), and almost three times the number of recent immigrants (11\% compared to $4 \%$ of the population immigrated in the five years preceding the 1996 census) $(9,10)$. The two study samples are likewise different. The majority of cases and controls (75\%) in the Montreal study were white (French Canadian, Jewish or Italian) (7). In the Vancouver study, $57 \%$ of cases and $74 \%$ of controls were white, while $37 \%$ of cases and 22\% of controls were Asian. Participants in the Montreal study were also better educated than participants in the Vancouver study. The majority of Montreal cases and controls had more than a community college degree while the majority of Vancouver cases and controls had the equivalent of or less than a community college degree.

Tobacco smoke is associated with exposure to numerous toxic chemicals including certain PAHs. It is therefore necessary to carefully control for tobacco use in any analysis evaluating the independent carcinogenic effects of traffic-related air pollution. Stratifying the analysis on smoking status can also provide additional insights about the absolute risk of traffic related air pollution (in the non-smoking population) and about potential interactions in the smoking population. In a case-control study conducted in Long Island (4), authors used a geographic traffic exposure dispersion model to estimate $\mathrm{PAH}$ exposure using $\mathrm{BaP}$ measurements and traffic counts. When the analyses were stratified on smoking status and menopausal status, significant associations between PAH exposure at time of menarche and breast cancer were only observed among non-smokers in the premenopausal model. A second 
case-control study presented a pooled analysis using PAH-DNA adducts measured by ELISA in peripheral mononuclear cells (15). In this analysis of 873 cases and 941 controls, risk of breast cancer was increased for those with detectable PAH-DNA adducts when compared to nondetectable adduct levels (age-adjusted $\mathrm{OR}=1.29,95 \% \mathrm{CI}: 1.05,1.58)(15)$. When stratified by cigarette smoking exposure, associations disappeared for former and current smokers (for nonsmokers: $\mathrm{OR}=1.48,95 \% \mathrm{CI}: 1.10,2.00$; for former smokers: $\mathrm{OR}=1.23,95 \% \mathrm{CI}$ : $0.86,1.76$; for current smokers: $\mathrm{OR}=0.99,95 \% \mathrm{CI}: 0.62,1.58)$. When the analyses were stratified by smoking status in this thesis project, no qualitative difference in effect estimates were observed (data not shown). However, these results are not directly comparable to the studies above, since PAHDNA adducts were not measured in this project and $\mathrm{NO}_{2}$ is not in itself hypothesized to be a cancer-causing agent, but rather a marker of a complex mixture of traffic-related air pollutants, which share some but not all the carcinogens in tobacco smoke.

In conclusion, most studies assessing the role of traffic-related air pollution and breast cancer have found inconsistent results pertaining to premenopausal and postmenopausal breast cancer and times of critical exposure Evidence of a dose-response is limited and most studies suffer from limitations in exposure assessment. Broadly speaking, ecologic approaches highlight potential areas of future study, but more often on their own do not produce high-level evidence of biologic associations. Biomarker studies provide accurate information on biologically relevant exposure doses but may not necessarily reflect long-term exposure. Modelling approaches, such as land-use regression, have the ability to historically estimate exposures while controlling for geographic factors such as meteorology and topography. While these approaches do rely on routinely collected proxy indicators which are often not the carcinogenic agents of interest in 
breast cancer etiology, the proxy indicators used are well correlated with the exposure of interest and $\mathrm{NO}_{2}$ in particular is a widely used proxy measure of traffic-related air pollution.

\subsection{Study validity: Methodological strengths and limitations}

\subsubsection{Selection bias}

There are several strengths and limitations of this project that should be addressed when assessing the internal validity of this study. Case-control studies are always vulnerable to selection bias and this study is no exception. Newly diagnosed breast cancer cases were ascertained from the BC Cancer Registry and controls were recruited from the Screening Mammography Program (SMP) of British Columbia (BC), a population-based breast cancerscreening mammography program. Because of the variability in the access and use of the SMP in $\mathrm{BC}$, there is a concern for a screening-related bias in this study (a type of volunteer bias). Women who attend screening mammography programs are typically more health-conscious (16), potentially better educated and wealthier.

Information on prior participation in a breast screening program was collected during the original interview with all participants. Consequently, it was possible to conduct sensitivity analysis excluding all cases who had never attended a breast cancer screening program, in an effort to ensure that the control group better reflected the underlying population that gave rise to the previously screened cases in the study. As described earlier, this sensitivity analysis led to a slightly higher $\mathrm{OR}$ for historical exposure to $\mathrm{NO}_{2}$ and premenopausal breast cancer but not postmenopausal breast cancer. 
It is also important to note that this case-control study essentially consists of volunteer patients and controls. If those cases and controls who agreed to participate differ systematically from the underlying eligible population of cases and controls, participation bias, a type of selection bias, may have been in introduced. While the response rates do not differ much between the cases and the controls, they are, nevertheless, considered low (54\% for cases and 57\% for controls). All cases diagnosed in the study area during 2005 to 2010 were contacted. Controls from the same city-level area in British Columbia were frequency-matched to a fiveyear age group and were randomly selected from the SMP. Each eligible control was given a random number and was approached in the order of the random number. The study's principal investigators in Vancouver sent invitation letters to participate in the study to both cases and controls. The approach used to recruit cases and controls is unlikely to have caused any bias in the results with respect to $\mathrm{NO}_{2}$ exposure. However, those that agreed to participate may be selectively different from those who did not participate with respect to important sociodemographic factors such as education and residential history. Unfortunately, the information required to compare responders to non-responders is not available. A comparison of the cases and controls suggests that more white women agreed to participate as controls, while a greater proportion of Asian women were recruited as cases. It is unlikely, however, that Asian women are in fact at higher risk for breast cancer in British Columbia and selection bias is likely an explanation for this observation. While it is difficult to control for selection bias, if information is available on the selection factors related to participation, controlling for these factors in the analysis can help minimize this bias. Therefore, most of the models described in this thesis are fully adjusted for socio-demographic factors and other breast cancer risk factors that may be related to participation in addition to $\mathrm{NO}_{2}$ exposure. 
Another related type of selection bias possible in the study population is the healthy immigrant effect, which occurs in high immigrant populations, such as that found in Vancouver. The healthy immigrant effect posits that people who have successfully immigrated are more likely to be healthy or health-conscious (17). In this study population, immigrants consumed significantly less alcohol and tobacco than Canadian-born participants. In the 1996 Canadian census, it was estimated that approximately $35 \%$ of Vancouver's population were immigrants (9). A sensitivity analysis excluding non-Canadian born participants was conducted to assess the healthy immigrant effect. This was a concern, in part, because a greater proportion of immigrants were cases and not controls. While the results of this analysis were not quantitatively different from the main analysis, the $\mathrm{OR}$ for historical exposure to $\mathrm{NO}_{2}$ and postmenopausal breast cancer was larger than in any of the other analyses and was comparable to estimates of effect observed recently by Hystad et al. $\left(\mathrm{OR}=1.07\right.$ per $10 \mathrm{ppb}$ increase in $\left.\mathrm{NO}_{2}\right)(6)$. These results suggest that there may be a mild bias introduced into this study because of the high proportion of immigrants in Vancouver that were recruited as cases but not controls.

To further assess this bias, an additional analysis was conducted that excluded nonCanadian born participants and also excluded cases who had never attended screening mammography. Women who were born in Canada and had participated in prior screening were observed to have an $\mathrm{OR}_{5 \mathrm{ppb}}$ of $1.13(95 \% \mathrm{CI}: 0.85,1.48)$ for the postmenopausal sample and an $\mathrm{OR}_{5 \mathrm{ppb}}$ of 1.37 (95\% CI: $\left.0.92,2.05\right)$ for the premenopausal sample. The resulting odds ratios are the strongest produced from all the models although not statistically significant. 


\subsubsection{Information bias and measurement error}

The strengths of this study include a relatively large study sample and a refined method of exposure assessment that provides a reasonable estimate of exposure at the individual-level. Compared to other exposure assessment methods, such as proximity to roads or biomarker measurements, land-use regression is able to combine not only pollutant measurements, but geographical features about the study area to improve prediction, and is able to estimate historical values for any year in the past, given measurements from fixed-site monitoring stations in that year. Exposure estimates also came from an independent data source and are unbiased.

Exposure to traffic-related air pollution was based on residential histories which were self-reported by participants in the questionnaire. Recall error (equal for cases and controls) is more of a concern especially for residential histories in the far past. The analyses for this project were limited to current residential address and residential address ten years prior to study entry. Participants were asked to give as much detail as possible and for as many addresses as they could remember, however many participants reported few addresses (on average 5.2 addresses) with limited data on years moved in and out. In the ten years before study entry, cases and controls provided on average 1.6 and 1.5 street addresses, respectively. A low proportion of women had more than three residences in the ten years prior to study entry (7.4\% of cases and $5.6 \%$ of controls, see Table 4-1 for more information), suggesting recall bias is likely not a concern. There were errors in the residential history from the participants themselves, or from data entry which resulted in a number of addresses not being geocoded. For the second analysis, which required the address from ten years before study entry, the number of errors in these addresses also increased (see Section 4.2.1). However, these observable errors in recalling past 
addresses did not differ between cases or controls. Therefore, this potential non-differential misclassification would have biased the effect estimate towards the null.

Measurement error may have arose due to the length of the questionnaire and concerns with data quality. While this questionnaire has not been formally validated, experts and peers in the field have used it previously. Studies have also shown that the length of questionnaires and surveys does not affect response quality, although variation in responses to questions nearer to the end of the questionnaire may be diminished $(18,19)$. In general, the information used to derive covariates came from questions in the first half of the questionnaire.

The bigger concern in this study is measurement error associated with the exposure assessment for $\mathrm{NO}_{2}$. The LUR model used was created by researchers at the University of British Columbia (1) and was able to explain $60 \%$ of the variability in the $\mathrm{NO}_{2}$ data from the fixed-site monitors. In contrast, the LUR model used in the Crouse Montreal study explained 80\% while the national LUR model in the Hystad study explained $73 \%$ of the variability in $\mathrm{NO}_{2}$ concentrations (6,7). Additionally, when geocoding participants, the national Hystad study geocoded to the six-digit postal codes given in residential histories while the Montreal study and this study geocoded participants to their home residences. Postal codes are accurate proxies for residence locations in urban areas, but may confer misclassified estimates of exposure in rural areas (6). As stated in Section 3.5.1, the highest values in the LUR models were truncated to a more reasonable value, giving a higher proportion of people than otherwise expected the maximum exposure of $\mathrm{NO}_{2}(30 \mathrm{ppb})$. This would have changed the distribution of $\mathrm{NO}_{2}$, reducing the variability in cases and controls, which would have in turn decreased the ability of this study to find a true association, if there was one. 
The method of back-extrapolation used involved inverse-distance weighting (IDW) fixed-site monitor measurements of historical $\mathrm{NO}_{2}$ to create interpolation maps of Vancouver in the past. The IDW process creates a shape based on the furthest monitoring station point. Since what was available in 1995 to 2000 fell inside the limits of the LUR study area, the overall number of participants who lived within this smaller study area was fewer than those geocoded in the LUR model (see Figure 3-2). While it does not seem likely that either cases or controls systematically lived outside of the IDW area, there was a significant difference in the proportions of cases and controls who were excluded due to falling outside the IDW area $(p=0.004)$. Additionally, when 2003 LUR NO 2 concentrations for participants who fell within the IDW area and for those who fell outside were compared, a significant difference in $\mathrm{NO}_{2}$ was found ( $\mathrm{p}<$ 0.001). This was expected, as fixed-site monitors (used in the creation of the IDW surfaces) are utilized to monitor high-pollution areas. The overall distribution of $\mathrm{NO}_{2}$ did not differ greatly when participants were excluded compared to the distribution of $\mathrm{NO}_{2}$ of the full study population.

There are also inherent errors which occur within the geocoding process, However when a small random sample of the results of the software used was compared to another, coordinates given did not differ by more than 50 meters in $>85 \%$ of the points. It is unlikely that any errors which did occur would systemically occur in one group over another; therefore the nondifferential misclassification which possibly arose from this would bias the effect estimate towards the null. Two studies assessed the accuracy of positions geocoded compared to positions according to Global Positioning System (GPS) satellite receivers (20,21). For a random sample of addresses, the studies found $79-81 \%$ of addresses to be within $100 \mathrm{~m}$ of the GPS locations and concluded that address geocoding is very accurate. 
$\mathrm{NO}_{2}$ exposure assignment may have been highly misclassified due to a number of reasons. Assessment of $\mathrm{NO}_{2}$ was based on home residence alone and for only two time points. Population mobility poses a major challenge to this exposure assessment approach since people do not necessarily spend all their time at home. A more accurate measure of exposure would have included the incorporation of $\mathrm{NO}_{2}$ data from other locations where women spent much of their time, such as their workplace. Reassuringly, however, in 2002, Leech et al. found that Canadian adults spent $66 \%$ of time at home, indoors and outside combined (22). Another source of misclassification may have come from not using a larger sample of residential history to estimate exposure. In the analyses conducted, one address was used for each participant to estimate exposure to traffic-related air pollution. If a participant recently moved to the address from an area of higher or lower pollution, the exposure estimate assigned would not represent their true exposure. A sensitivity analysis was conducted including only participants who have lived at their address at study entry for the past ten years and effect estimates produced were slightly stronger than those in the original analyses, however not statistically significant. A better approach may be to estimate a time-weighted average of exposure over the entire residential history, similar to the analyses conducted by Hystad et al. (6). Misclassification produced from having many addresses does not appear to be systematically different between cases and controls and would therefore be non-differential. In addition, differences in individual behaviours may have also resulted in exposure misclassification. For example, the type of building a participant lived in may have affected their exposure estimate: the exposure associated with living on the top floor of a high-rise condominium may not be the same as the exposure assigned at ground-level of the same address. These are limitations due to the nature of the data collected although the 
type of misclassification is most likely non-differential and would bias the estimate of effect towards the null.

Finally, assessing exposure to $\mathrm{NO}_{2}$ further back in time may have been more appropriate for breast cancer due to its long latency. Hystad et al. modeled calculated 20-year averages, excluding women who had not provided at least 18 years of residential history (6). However, the data quality in this case-control study became increasingly compromised as women reported residential histories further than ten years back in time and there were fewer women with complete addresses in the Vancouver region as far back as 20 years (578 cases and 574 controls, approximately $60 \%$ of the original population, prior to stratification on menopausal status).

In summary, while residential histories were self-reported, participants were unlikely to systematically remember addresses better due to disease status, so recall bias is not thought to be an important concern, although possible non-differential misclassification from many sources remains an issue.

\subsubsection{Confounding}

In this study, a fully-adjusted model was presented to address some of the concerns with the screening-related bias and to allow for the comparison of results to two other Canadian studies that used an LUR approach to estimate the association between $\mathrm{NO}_{2}$ and breast cancer, while adjusting for well-established and suspected risk factors for breast cancer. When compared to the age-adjusted models, in some cases, the effect estimates are quite different. Particularly in the results for the third and fourth sensitivity analyses, inclusion of all covariates in the final models greatly changed the effect estimates when exposure was estimated at ten years prior to 
study entry (eg, the age-adjusted $\mathrm{OR}_{5 \mathrm{ppb}}$ for premenopausal women was 0.99 and the fullyadjusted $\mathrm{OR}_{5 \mathrm{ppb}}$ was 1.20 in the screening attendance sensitivity analysis, see Table 4.11B). This suggests possible bias or confounding may exist when the combination of covariates are not all included, although a confounder assessment exercise did not identify any individual confounders using the $10 \%$ minimum change-in-estimate approach (data not shown).

\subsubsection{Study power and chance}

In the proposal stage of this thesis project, power was calculated based on a number of assumptions about sample size and exposure distribution. Without extensively analyzing the study population prior to the proposal, it was assumed 876 cases and 824 controls were eligible for the study. In fact, the analysis with the smallest sample size was the fourth sensitivity analysis on premenopausal breast cancer (93 cases and 159 controls) - which results in a power of $72 \%$ when using the original assumptions about the exposure distribution. It was also assumed from the original LUR methods paper (1) that the exposure distribution of $\mathrm{NO}_{2}$ was normally distributed (the paper reported that only the $\mathrm{NO}_{2}$ measurements from the monitoring stations were normally distributed). When the actual distribution of estimated $\mathrm{NO}_{2}$ from the LUR model was examined, cases and controls had a mean exposure of $18.1 \mathrm{ppb}$ with a standard deviation of $3.8 \mathrm{ppb}$ and was not normally distributed. Therefore, despite the high power calculated for this study, it is possible that power was overestimated given the assumption that the exposure was normally distributed. Furthermore, all of the analyses were stratified by menopausal status, which further reduced the study power. The calculation of post hoc power is also considered to have no additional insight once confidence intervals are constructed (23). 
For all analyses, the confidence intervals (CI) for the odds ratios crossed the null value of one. It may be due to the lack of variation in the exposure: if a threshold effect exists for the relationship between $\mathrm{NO}_{2}$ and breast cancer, this study may not have had the correct range of exposures to detect any real associations. Results were also somewhat inconsistent with the previous literature for the postmenopausal models, until certain exclusion criteria were applied. The sensitivity analyses may be the more robust analyses; however with reduced sample sizes, the ability to detect a statistically significant effect is diminished.

\subsubsection{External validity}

Assuming that the restricted and fully-adjusted effect estimates are the most reliable, these are the results that are potentially generalizable to the Vancouver population. However, as mentioned previously, these results may be modified by immigrant status and generalizability would then depend on the distribution of immigrants in the target population.

\subsection{Conclusions and future research directions}

The purpose of this thesis was to examine the association between traffic-related air pollution exposure and breast cancer incidence using estimated nitrogen dioxide $\left(\mathrm{NO}_{2}\right)$ as a proxy for traffic-related air pollution exposure. While the results for the two main analyses (the first using the home address at time of study entry to assign a $\mathrm{NO}_{2}$ exposure for the year 2003 and the second using the home address ten years prior to study entry) were not statistically significant, effect estimates approached those observed in the previous literature in the sensitivity analyses conducted. Of note are the sensitivity analyses which excluded cases who have never 
attended screening mammography and/or excluded participants who were not born in Canada. In these analyses, consistently increased odds ratios were observed for premenopausal women. Further research into the relationship between traffic-related air pollution and breast cancer is warranted, especially within the population of premenopausal women. Since there is a large immigrant population in the study region used in this thesis, future studies should focus on collecting large sample sizes in each immigrant status group to allow for more in-depth analyses.

Other future research should include nesting case-control studies within prospective cohort studies which routinely collect biologic samples. Currently, a large-scale prospective study is being conducted across Canada known as the Tomorrow Project (24). Biologic specimens are collected from participants and markers of air pollution exposure can be determined from these. Paolo Vineis at the London Imperial College in the UK is currently running a research program in Greece, Sweden, and Italy evaluating envirogenomarkers in the population to study the role of environmental agents (including traffic-related air pollution) in chronic disease causation (http://www.envirogenomarkers.net/). By using prospective cohort studies and nested case-control studies, factors that may influence ingestion and metabolism of pollutants can be identified (25).

Conducting a similar study in a city or cities with a larger range in $\mathrm{NO}_{2}$ or traffic-related air pollutants would also improve power to detect smaller measures of effect. The method of exposure assessment used in this thesis, land-use regression, is limited as well in its assumption of how pollutants are distributed across an urban area. Increasingly, hybrid models are being used to assess air pollutant concentrations, combining methods such as land-use regression or interpolation with remote sensing (using satellite data) (26). These methods are cost-effective 
and can be applied to large geographic areas; however the resolution of pollutant concentrations may not be sufficient enough to be applied at the level of an individual's house. Ideally, participants would be given personal air monitoring devices to measure personal exposures. Since this type of exposure assessment is only suited to prospective cohort studies, future studies using a similar method to LUR may use personal air monitoring devices to validate the estimates from the LUR models.

Finally, future research should include time activity diaries to capture information on time spent away from home and details about occupational and other exposures to air pollutants. This will allow for more accurate assessment of traffic-related air pollution exposure and help account for concerns of population mobility. If possible, assessing exposure at times thought to be critical to breast development, such as menarche or first pregnancy, may elucidate the nature and role of traffic-related air pollution in breast cancer etiology.

Given that ambient air pollution is a ubiquitous exposure that occurs in generally low concentrations in North America, using multiple and large cities will allow for the greatest ability to detect important associations, if they exist. The next step in environmental epidemiology research is to conduct nested case-control studies within large prospective studies, such as the Canadian Tomorrow Project, which routinely collects biologic specimens, to better ensure internally valid and robust methodological research. 


\subsection{References}

1. Henderson SB, Beckerman B, Jerrett M, Brauer M. Application of land use regression to estimate long-term concentrations of traffic-related nitrogen oxides and fine particulate matter. Environ Sci Technol 2007;41(7):2422-2428.

2. Raaschou-Nielsen O, Andersen ZJ, Hvidberg M, Jensen SS, Ketzel M, Sorensen M, et al. Air pollution from traffic and cancer incidence: a Danish cohort study. Environ Health 2011;10(1):67.

3. Lewis-Michl EL, Melius JM, Kallenbach LR, Ju CL, Talbot TO, Orr MF. Breast cancer risk and residence near industry or traffic in Nassau and Suffolk Counties, Long Island, New York. Archives of Environmental Health: An International Journal 1996;51(4):255-265.

4. Nie J, Beyea J, Bonner MR, Han D, Vena JE, Rogerson P, et al. Exposure to traffic emissions throughout life and risk of breast cancer: the Western New York Exposures and Breast Cancer (WEB) study. Cancer Causes \& Control 2007;18(9):947-955.

5. Bonner MR, Han D, Nie J, Rogerson P, Vena JE, Muti P, et al. Breast cancer risk and exposure in early life to polycyclic aromatic hydrocarbons using total suspended particulates as a proxy measure. Cancer Epidemiology Biomarkers \& Prevention 2005;14(1):53-60.

6. Hystad P, Villeneuve PJ, Goldberg MS, Crouse DL, Johnson K, Canadian Cancer Registries Epidemiology Research Group. Exposure to traffic-related air pollution and the risk of developing breast cancer among women in eight Canadian provinces: A case-control study. Environ Int 2015;74:240-248. 
7. Crouse DL, Goldberg MS, Ross NA, Chen H, Labrèche F. Postmenopausal breast cancer is associated with exposure to traffic-related air pollution in Montreal, Canada: a case-control study. Environ Health Perspect 2010;118(11):1578.

8. Chen H, Goldberg MS, Crouse DL, Burnett RT, Jerrett M, Villeneuve PJ, et al. Backextrapolation of estimates of exposure from current land-use regression models. Atmos Environ 2010;44(35):4346-4354.

9. Statistics Canada. Selected trend data for Vancouver (CMA), 1996, 2001 and 2006 censuses. 2010; Available at: http://www12.statcan.gc.ca/census-recensement/2006/dp-pd/92-596/P12.cfm?TID=0\&Lang=eng\&T=CMA\&PRCODE=59\&GEOCODE=933. Accessed 01/07, 2014.

10. Statistics Canada. Selected trend data for Montréal (CMA), 1996, 2001 and 2006 censuses. 2010; Available at: http://www12.statcan.gc.ca/census-recensement/2006/dp-pd/92-596/P12.cfm?Lang=eng\&T=CMA\&PRCODE $=24 \&$ GEOCODE $=462 \&$ GEOLVL $=$ CMA $\& T I D=0$. Accessed 01/07, 2014.

11. Schwela D. Air pollution and health in urban areas. Rev Environ Health 2000;15(1-2):13-42.

12. Mayer H. Air pollution in cities. Atmos Environ 1999;33(24):4029-4037.

13. Environment Canada. International Comparison of Urban Air Quality. 2014; Available at: https://www.ec.gc.ca/indicateurs-indicators/default.asp?lang=en\&n=FDBB2779-1. Accessed 01/10, 2014.

14. Blowin' in the wind: Canada's smoggiest places. Canadian Geographic 2000. 
15. Gammon MD, Sagiv SK, Eng SM, Shantakumar S, Gaudet MM, Teitelbaum SL, et al. Polycyclic aromatic hydrocarbon-DNA adducts and breast cancer: a pooled analysis. Archives of Environmental Health: An International Journal 2004;59(12):640-649.

16. Aarts M, Voogd A, Duijm L, Coebergh J, Louwman W. Socioeconomic inequalities in attending the mass screening for breast cancer in the south of the Netherlands - associations with stage at diagnosis and survival. Breast Cancer Res Treat 2011;128(2):517-525.

17. Kennedy S, McDonald JT, Biddle N. The healthy immigrant effect and immigrant selection: evidence from four countries 2006.

18. Subar AF, Ziegler RG, Thompson FE, Johnson CC, Weissfeld JL, Reding D, et al. Is shorter always better? Relative importance of questionnaire length and cognitive ease on response rates and data quality for two dietary questionnaires. Am J Epidemiol 2001 Feb $15 ; 153(4): 404-409$.

19. Burchell B, Marsh C. The effect of questionnaire length on survey response. Quality and Quantity 1992;26(3):233-244.

20. Ward MH, Nuckols JR, Giglierano J, Bonner MR, Wolter C, Airola M, et al. Positional accuracy of two methods of geocoding. Epidemiology 2005;16(4):542-547.

21. Bonner MR, Han D, Nie J, Rogerson P, Vena JE, Freudenheim JL. Positional accuracy of geocoded addresses in epidemiologic research. Epidemiology 2003 Jul;14(4):408-412.

22. Leech JA, Nelson WC, Burnett RT, Aaron S, Raizenne ME. It's about time: a comparison of Canadian and American time-activity patterns. J Expo Anal Environ Epidemiol 2002 Nov;12(6):427-432.

23. Hoenig JM, Heisey DM. The abuse of power. The American Statistician 2001;55(1). 
24. Borugian MJ, Robson P, Fortier I, Parker L, McLaughlin J, Knoppers BM, et al. The Canadian Partnership for Tomorrow Project: building a pan-Canadian research platform for disease prevention. CMAJ 2010 Aug 10;182(11):1197-1201.

25. Chadeau-Hyam M, Athersuch TJ, Keun HC, De Iorio M, Ebbels TM, Jenab M, et al. Meeting-in-the-middle using metabolic profiling-a strategy for the identification of intermediate biomarkers in cohort studies. Biomarkers 2011;16(1):83-88.

26. Zou B, Wilson JG, Zhan FB, Zeng Y. Air pollution exposure assessment methods utilized in epidemiological studies. Journal of Environmental Monitoring 2009;11(3):475-490. 


\section{Appendix A}

\section{Ethics Approval}

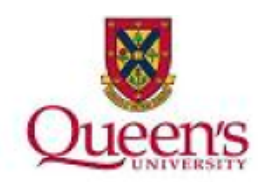

\section{QUEEN'S UNIVERSITY HEALTH SCIENCES AND AFFILIATED TEACHING HOSPITALS RESEARCH ETHICS BOARD ANNUAL RENEWAL}

Queen's University, in accordance with the "Tri-Council Policy Statement 2, 2010" prepared by the Interagency Advisory Panel on Research Ethics for the Canadian Institutes of Health Research, Natural Sciences and Engineering Research Council of Canada and Social Sciences and Humanities Research Council of Canada requires that research projects involving human participants be reviewed annually to determine their acceptability on ethical grounds.

A Research Ethics Board composed of:

Dr. A.F. Clark, Emeritus Professor, Department of Biomedical and Molecular Sciences, Queen's University (Chair)

Dr. H. Abdollah, Professor, Department of Medicine, Queen's University

Dr. C. Cline, Assistant Professor, Department of Medicine, Director, Office of Bioethics, Queen's University, Clinical Ethicist, Kingston General Hospital

Dr. R. Brison, Professor, Department of Emergency Medicine, Queen's University

Dr. M. Evans, Community Member

Ms. J. Hudacin, Community Member

Mr. D. McNaughton, Community Member

Ms. S. Rohland, Privacy Officer, ICES-Queen's Health Services Research Facility, Research Associate,

Division of Cancer Care and Epidemiology, Queen's Cancer Research Institute

Dr. M. Sawhney, Assistant Professor, School of Nursing, Queen's University

Dr. A. Singh, Professor, Department of Psychiatry, Queen's University

Dr. J. Walia, Assistant Professor and Clinical Geneticist, Department of Paediatrics, Queen's University and Ms. K. Weisbaum, LL.B. and Adjunct Instructor, Department of Family Medicine (Bioethics)

has reviewed the request for renewal of Research Ethics Board approval for the project "Mapping the risk of postmenopausal breast cancer to exposure from traffic-related air pollution using land-use regression in Vancouver, BC" as proposed by Ms. N. Kwon of the Department of Public Health Sciences, at Queen's University. The approval is renewed for one year, effective June 26, 2014. If there are any further amendments or changes to the protocol affecting the participants in this study, it is the responsibility of the principal investigator to notify the Research Ethics Board. Any unexpected serious adverse event occurring locally must be reported within 2 working days or earlier if required by the study sponsor. All other adverse events must be reported within 15 days after becoming aware of the information.

Quent 2. Clank

Date: May 30, 2014

Chair, Health Sciences Research Ethics Board

Renewal 1[x] Renewal 2 [ ] Extension [ ] Code\# EPID-432-13 Romeo file\# 6010248 


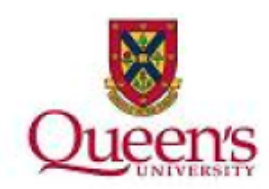

\section{QUEEN'S UNIVERSITY HEALTH SCIENCES \& AFFILIATED TEACHING HOSPITALS RESEARCH ETHICS BOARD}

The membership of this Research Ethics Board complies with the membership requirements for Research Ethics Boards and operates in compliance with the Tri-Council Policy Statement; Part C Division 5 of the Food and Drug Regulations, OHRP, and U.S DHHS Code of Federal Regulations Title 45, Part 46 and carries out its functions in a manner consistent with Good Clinical Practices.

Federalwide Assurance Number: \#FWA00004184, \#IRB00001173

Current 2013 membership of the Queen's University Health Sciences \& Affiliated Teaching Hospitals Research Ethics Board:

Dr. A.F. Clark, Emeritus Professor, Department of Biomedical and Molecular Sciences, Queen's University (Chair)

Dr. H. Abdollah, Professor, Department of Medicine, Queen's University

Dr. R. Brison, Professor, Department of Emergency Medicine, Queen's University

Dr. C. Cline, Assistant Professor, Department of Medicine, Director, Office of Bioethics, Queen's University, Clinical Ethicist, Kingston General Hospital

Dr. M. Evans, Community Member

Dr. C. Godfrey, Assistant Professor, School of Nursing, Queen's University

Ms. J. Hudacin, Community Member

Dr. J. MacKenzie, Pediatric Geneticist, Department of Paediatrics, Queen's University

Mr. D. McNaughton, Community Member

Ms. P. Newman, Pharmacist, Clinical Care Specialist and Clinical Lead, Quality and Safety, Pharmacy Services, Kingston General Hospital

Ms. S. Rohland, Privacy Officer, ICES-Queen's Health Services Research Facility, Research Associate, Division of Cancer Care and Epidemiology, Queen's Cancer Research Institute

Dr. B. Simchison, Assistant Professor, Department of Anesthesiology and Perioperative Medicine, Queen's University

Dr. A. Singh, Professor, Department of Psychiatry, Queen's University

Ms. K. Weisbaum, LL.B. and Adjunct Instructor, Department of Family Medicine (Bioethics) 


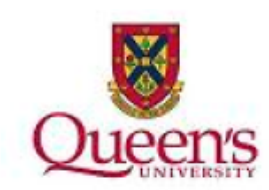

\title{
QUEEN'S UNIVERSITY HEALTH SCIENCES \& AFFILIATED TEACHING HOSPITALS RESEARCH ETHICS BOARD-DELEGATED REVIEW
}

June 26,2013

\author{
Ms. Nicollette Kwon \\ Department of Community Health and Epidemiology \\ Queen's Cancer Research Institute \\ Queen's University \\ Dear Ms. Kwon
}

Study Title: EPID-432-13 Mapping the risk of postmenopausal breast cancer to exposure from traffic-related air pollution using land-use regression in Vancouver, BC

File \# 6010248

Co-Investigators: Dr. H. Richardson

I am writing to acknowledge receipt of your recent ethics submission. We have examined the protocol for your project (as stated above) and consider it to be ethically acceptable. This approval is valid for one year from the date of the Chair's signature below. This approval will be reported to the Research Ethics Board. Please attend carefully to the following listing of ethics requirements you must fulfill over the course of your study:

Reporting of Amendments: If there are any changes to your study (e.g. consent, protocol, study procedures, etc.), you must submit an amendment to the Research Ethics Board for approval. Please use event form: HSREB MultiUse Amendment/Full Board Renewal Form associated with your post review file \# 6010248 in your Researcher Portal (https://eservices.queensu.ca/romeo_researcher/)

Reporting of Serious Adverse Events: Any unexpected serious adverse event occurring locally must be reported within 2 working days or earlier if required by the study sponsor. All other serious adverse events must be reported within 15 days after becoming aware of the information. Serious Adverse Event forms are located with your postreview file 6010248 in your Researcher Portal (https://eservices.queensu.ca/romeo_researcher/)

Reporting of Complaints: Any complaints made by participants or persons acting on behalf of participants must be reported to the Research Ethics Board within 7 days of becoming aware of the complaint. Note: All documents supplied to participants must have the contact information for the Research Ethics Board.

Annual Renewal: Prior to the expiration of your approval (which is one year from the date of the Chair's signature below), you will be reminded to submit your renewal form along with any new changes or amendments you wish to make to your study. If there have been no major changes to your protocol, your approval may be renewed for another year.

Yours sincerely,

$$
\text { Quent 2. Clakk. }
$$

Chair, Research Ethics Board

June 26, 2013

Investigators please note that if your trial is registered by the sponsor, you must take responsibility to ensure that the registration information is accurate and complete 


\section{Appendix B}

\section{Canadian Breast Cancer Study Questionnaire}

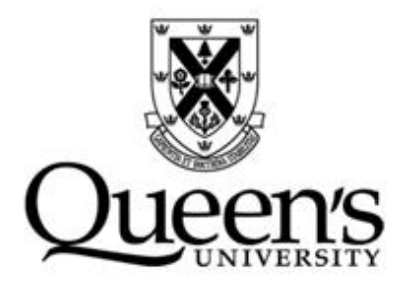

\section{STUDY OF ENVIRONMENT, GENES AND BREAST HEALTH RESEARCH QUESTIONNAIRE}

This questionnaire is part of a research study to understand the relationship between a woman's environment, her genes and breast health. The specific objectives are to investigate the association between exposure to certain environmental factors, including fossil fuels from vehicle exhaust, and light exposure at night, and breast diseases. We also wish to determine if some women are more genetically susceptible to exposures that would put them at higher risk for breast diseases.

Please prepare answers to the following questions to the best of your ability. If you choose to respond by telephone, we expect that it will take approximately one hour to collect your answers. If you are able to prepare your answers ahead of time, the interview should take less time. Alternatively, you may return this completed questionnaire by mail in the prepaid envelope provided.

The answers that you share with us will be strictly confidential and identified by an encrypted code, known by selected members of our research team only. Your honesty is important for the success of this research, and any answer is better than no answer.

We appreciate your cooperation tremendously.

\section{Thank you!}


GENERAL INFORMATION

Please answer each question as completely as possible. If you are unsure of an exact answer, give your best estimate.

Today's Date:

Month / day / year

1. When were you born?

$$
\text { Month / day / year }
$$

2. What is the highest grade of school you have completed?

Some elementary (grade) school

Completed elementary (grade) school

Some secondary (high) school

Completed secondary (high) school

Trade certificate or diploma from a vocational school or apprenticeship training

Certificate or diploma from a community college or CEGEP

University degree (bachelor's degree)

$\checkmark$ Graduate or professional school degree (above bachelor's degree)

3. What is your current employment status?
employed (full-time)
homemaker
$\square$ employed (part-time)
student
$\square$ self-employed (full-time)
retired
self-employed (part-time)
unemployed

4. Were you born in Canada?

Yes
No, I was born in 
GENERAL INFORMATION (Cont'd)

5. How would you best describe you and your grandparent's race, ethnicity or colour? Please specify as many as applicable:

\begin{tabular}{|c|c|c|c|c|c|}
\hline $\begin{array}{l}\text { Race, ethnicity or } \\
\text { colour }\end{array}$ & Yourself & $\begin{array}{c}\text { Your } \\
\text { Maternal } \\
\text { Grandmother }\end{array}$ & $\begin{array}{c}\text { Your } \\
\text { Maternal } \\
\text { Grandfather }\end{array}$ & $\begin{array}{c}\text { Your } \\
\text { Paternal } \\
\text { Grandmother }\end{array}$ & $\begin{array}{c}\text { Your } \\
\text { Paternal } \\
\text { Grandfather }\end{array}$ \\
\hline White & 口 & $\square$ & 口 & 口 & $\square$ \\
\hline Chinese & 口 & ם & ם & 口 & 口 \\
\hline $\begin{array}{l}\text { South Asian (e.g. } \\
\text { East } \\
\text { Indian, Pakistani, } \\
\text { Punjabi, Sri Lankan) }\end{array}$ & $\square$ & 口 & 口 & $\square$ & $\square$ \\
\hline Black & ם & ם & ם & ם & ם \\
\hline $\begin{array}{l}\text { Native/Aboriginal } \\
\text { peoples } \\
\text { of North America }\end{array}$ & $\square$ & $\square$ & $\square$ & 口 & 口 \\
\hline $\begin{array}{l}\text { Arab/West Asian } \\
\text { (e.g. Armenian, } \\
\text { Egyptian, Iranian, } \\
\text { Lebanese, Moroccan) }\end{array}$ & 口 & ם & ם & 口 & 口 \\
\hline Filipino & 口 & 口 & 口 & $\square$ & $\square$ \\
\hline $\begin{array}{l}\text { South East Asian } \\
\text { (e.g. Cambodian, } \\
\text { Indonesian, } \\
\text { Laotian, Vietnamese) }\end{array}$ & 口 & 口 & 口 & ם & ם \\
\hline Latin America & $\square$ & 口 & $\square$ & 口 & 口 \\
\hline Japanese & $\square$ & 口 & 口 & $\square$ & 口 \\
\hline Korean & 口 & 口 & a & a & 口 \\
\hline Other (Specify) & & & & & \\
\hline
\end{tabular}




\section{HEALTH AND MEDICAL BACKGROUND}

6. What is your height? (feet and inches) or $(\mathrm{cm})$

7. What is your current weight? _ (lbs) or $(\mathrm{kg})$

8. a) What was your weight 2 years ago? (kg) (lbs) or

b) What was your weight when you were 25 years old? (lbs) or $(\mathrm{kg})$

9. Not including pregnancy, what is the most you have weighed? (lbs) or_

10. How old were you when you had your first menstrual period? years of age $\square$ Have never menstruated (go to question \#13)

11. Are you still menstruating?

$\square$ Yes (go to question \#14)

a No

$\downarrow$

How many years has it been since your last menstrual period? years

12. How did your menstrual periods stop?

Naturally (through onset of menopause)

As a result of a hysterectomy

As a result of radiation or chemotherapy

Other - please specify:

13. Have you ever had a hysterectomy (that is, an operation to remove the womb/uterus)?

ㄱo

Yes - at what age? _ years

14. Have you ever had an oopherectomy (that is, an operation to remove one or both of your ovaries which is sometimes done at the same time as removal of the womb/uterus)?

- No

Yes, one ovary removed: $\rightarrow$ at what age? years

Yes, second or both ovaries removed: $\rightarrow$ at what age? _ years

Don't know

15. Have you ever had a tubal ligation (that is, sterilization by having your "tubes tied")?

No

Yes - at what age? _ years 


\section{HEALTH AND MEDICAL BACKGROUND (Cont'd)}

16. Have you ever taken fertility drugs (e.g. Clomiphene, Clomid, Serophene, etc.)

$\square$ No (go to question \#17)

$\square$ Yes

$\downarrow$

Please provide details. If you don't remember the name, fill in the type, date started, date stopped and duration if possible. If you don't remember the month, please fill in the year. In calculating total duration, please include only the time periods that you used the specific medication.

\begin{tabular}{|c|c|l|l|l|}
\hline Brand Name & $\begin{array}{c}\text { Medication } \\
\text { Type }\end{array}$ & $\begin{array}{l}\text { Date Started } \\
\text { (Month- } \\
\text { Year) }\end{array}$ & $\begin{array}{l}\text { Date Stopped } \\
\text { (Month-Year) }\end{array}$ & $\begin{array}{l}\text { Total } \\
\text { Duration }\end{array}$ \\
\hline $\begin{array}{c}\text { Example: } \\
\text { Clomiphene }\end{array}$ & Pill & Sept-1999 & Oct-2002 & 3 yrs \\
\hline & & & & \\
\hline & & & & \\
\hline & & & & \\
\hline & & & & \\
\hline
\end{tabular}

17. Have you ever taken prescribed birth control medication for birth control or any other medical reason for 6 months or more? (e.g. Norplant, Norinyl, Demulen, Depo-Provera, Tri-Cyclen, Alesse, etc.)

No (go to question \#18)

$\square$ Yes<smiles>[AlH]</smiles>

Please provide details. If you don't remember the name, fill in the type, date started, date stopped and duration if possible. If you don't remember the month, please fill in the year. In calculating total duration, please include only the time periods that you used the specific medication.

\begin{tabular}{|c|c|l|c|c|}
\hline $\begin{array}{c}\text { Brand } \\
\text { Name }\end{array}$ & Medication Type & $\begin{array}{l}\text { Date Started } \\
\text { (Month- } \\
\text { Year) }\end{array}$ & $\begin{array}{l}\text { Date Stopped } \\
\text { (Month-Year) }\end{array}$ & Total Duration \\
\hline $\begin{array}{c}\text { Example: } \\
\text { Norinyl }\end{array}$ & Pill & Sept-1990 & Oct-1998 & 8 yrs \\
\hline & & & & \\
\hline
\end{tabular}




\section{HEALTH AND MEDICAL BACKGROUND (Cont'd)}

18. Have you ever been prescribed antidepressants? (e.g. Fluoxetine (sold as Prozac), Nortriptyline (sold as Allegron), etc.)

$\square$ No (go to question \#19)

$\square$ Yes<smiles>[AlH]</smiles>

Please provide details. If you don't remember the name, fill in the type, strength, date started, date stopped and duration if possible. If you don't remember the month, please fill in the year. In calculating total duration, please include only the time periods that you used the specific medication.

\begin{tabular}{|c|c|c|c|c|c}
\hline Brand Name & $\begin{array}{c}\text { Medication } \\
\text { Type }\end{array}$ & $\begin{array}{c}\text { Strength } \\
\text { (milligrams) }\end{array}$ & $\begin{array}{c}\text { Date Started } \\
\text { (Month-Year) }\end{array}$ & $\begin{array}{c}\text { Date Stopped } \\
\text { (Month-Year) }\end{array}$ & $\begin{array}{c}\text { Total } \\
\text { Duration }\end{array}$ \\
\hline $\begin{array}{c}\text { Example: } \\
\text { Prozac }\end{array}$ & Pill & 20 & Nov-1990 & Feb-1994 & 4 yrs \\
\hline & & & & & \\
\hline
\end{tabular}

19. Have you ever taken aspirin, ibuprofen or other nonsteroidal anti-inflammatory (NSAIDs) pain medication or tylenol or other acetaminophen pain medication for at least once per week for 6 months or longer?

No (go to question \#20)

$\square$ Yes

$\downarrow$

Please provide details. If you don't remember the name, fill in the type, strength, number of tablets per week, date started, date stopped and duration if possible. If you don't remember the month, please fill in the year. In calculating total duration, please include only the time periods that you used the specific medication.

\begin{tabular}{|c|c|c|c|c|c|c|}
\hline Brand Name & $\begin{array}{c}\text { Medication } \\
\text { Type }\end{array}$ & $\begin{array}{c}\text { Strength } \\
(\mathrm{mg})\end{array}$ & $\begin{array}{c}\text { Number of } \\
\text { Tablets/Week }\end{array}$ & $\begin{array}{c}\text { Date } \\
\text { Started }\end{array}$ & $\begin{array}{c}\text { Date } \\
\text { Stopped }\end{array}$ & $\begin{array}{c}\text { Total } \\
\text { Duration }\end{array}$ \\
\hline $\begin{array}{c}\text { Example: } \\
\text { Tylenol }\end{array}$ & Pill & 200 & 28 & Jan-1995 & Nov-1995 & 11 months \\
\hline & & & & & & \\
\hline & & & & & & \\
\hline & & & & & & \\
\hline & & & & & & \\
\hline
\end{tabular}




\section{HEALTH AND MEDICAL BACKGROUND (Cont'd)}

20. Have ever taken any type of female replacement hormones (presently known as hormone therapy or HT and previously called hormone replacement therapy or HRT? (e.g. Estrace, Premarin, etc.)

$\square$ Yes

No (go to question\# 22)<smiles>[AlH]</smiles>

Please provide details. If you don't remember the name, fill in the type, date started, date stopped and duration if possible. In calculating total duration, please include only the time periods that you used the specific medication.

\begin{tabular}{|c|c|c|c|c|c|}
\hline \multirow[b]{2}{*}{$\begin{array}{l}\text { Brand } \\
\text { Name }\end{array}$} & \multicolumn{2}{|c|}{ Medication Type } & \multicolumn{2}{|c|}{ Date } & \multirow[b]{2}{*}{ Total Duration } \\
\hline & $\begin{array}{c}\text { Indicate if } \\
\text { estrogen and/or } \\
\text { progesterone }\end{array}$ & $\begin{array}{l}\text { Indicate method } \\
\text { of use } \\
\text { (oral, patch, } \\
\text { etc.) }\end{array}$ & $\begin{array}{l}\text { Started } \\
\text { (Month- } \\
\text { Year) }\end{array}$ & $\begin{array}{l}\text { Stopped } \\
\text { (Month- } \\
\text { Year) }\end{array}$ & \\
\hline $\begin{array}{l}\text { Example: } \\
\text { Premarin }\end{array}$ & Estrogen only & Oral & Feb-1963 & Mar-1995 & $29 y r s$ \\
\hline & & & & & \\
\hline
\end{tabular}

21. Are you currently taking any type of hormone therapy or HT (e.g. Estrase, Premarin, etc.)?

a Yes a No

The following questions are about screening for breast disease.

22. Have you ever had a mammogram (i.e. a breast $\mathrm{x}$-ray)?

a Yes

No (go to question \#23)

$\downarrow$

How old were you the first time you went for a mammogram? years

What was the reason?

How many times have you had a mammogram since the first time?

When was the last time? (i.e. 6 months ago? 5 or more years ago?)

23. Have you ever examined your own breasts for lumps?

- Yes

No (go to question \#24)

$\downarrow$

How old were you when you first started? years

How often do you examine your breasts for lumps?

$\begin{array}{llll}\square \text { Weekly } & \square \text { Monthly } & \square \text { Quarterly (every 3 months) } & \square \text { Yearly } \\ \square \text { Bi-weekly } & \square \text { Bi-monthly } & \square \text { Twice per year } & \square \text { Unsure }\end{array}$ 


\section{HEALTH AND MEDICAL BACKGROUND (Cont'd)}

24. These questions are about breast lumps or cysts that you had more than a vear ago.

\begin{tabular}{|l|c|c|}
\cline { 2 - 3 } \multicolumn{1}{c|}{} & Left breast & Right breast \\
\hline $\begin{array}{l}\text { Have you ever had a lump or cyst in } \\
\text { your breast? } \text { (if no to both left and } \\
\text { right breast, go to question \#25) }\end{array}$ & Yes $\square$ & Yes $\square$ \\
\hline $\begin{array}{l}\text { How old were you when the first } \\
\text { lump/cyst appeared? }\end{array}$ & No $\square$ & No $\square$ \\
\hline $\begin{array}{l}\text { Did you have any of the lumps/cysts } \\
\text { examined by a doctor? }\end{array}$ & Yes $\square$ & Age \\
\hline $\begin{array}{l}\text { Did you have a biopsy or fine needle } \\
\text { aspiration for any of the lumps/cysts? }\end{array}$ & No $\square$ & Yes $\square$ \\
\hline $\begin{array}{l}\text { Did a doctor diagnose any of the } \\
\text { lumps/cysts as breast cancer? }\end{array}$ & No $\square$ & No $\square$ \\
\hline
\end{tabular}




\section{PREGNANCY}

25. Have you ever been pregnant? (include live births, still births, miscarriages and abortions)

$\square$ Yes $\quad \square$ No (go to question \#26)

What is the total number of pregnancies? (include live births, still births, miscarriages and abortions)

Please fill in the following information for each of your pregnancies:

\begin{tabular}{|c|c|c|c|c|}
\hline & $\begin{array}{c}\text { Age at } \\
\text { beginning } \\
\text { of pregnancy } \\
\text { (years) }\end{array}$ & Outcome & $\begin{array}{c}\text { Weeks } \\
\text { pregnancy } \\
\text { lasted } \\
\text { (weeks) }\end{array}$ & $\begin{array}{c}\text { Number of months } \\
\text { breast feeding }\end{array}$ \\
\hline $\begin{array}{l}1^{\text {st }} \\
\text { Pregnancy }\end{array}$ & & \begin{tabular}{|}
$\square$ Single live \\
birth \\
$\square$ Multiple live \\
births \\
$\square$ Stillbirth \\
$\square$ Miscarriage \\
$\square$ Abortion
\end{tabular} & & $\begin{array}{l}\square \text { Not applicable } \\
\square \text { Did not breast } \\
\text { feed } \\
\square 1 \text { - } 2 \text { months } \\
\square 3-4 \text { months } \\
\square 5-6 \text { months } \\
\square 7-12 \text { months } \\
\square>12 \text { months }\end{array}$ \\
\hline
\end{tabular}

\begin{tabular}{|c|c|c|c|c|}
\hline & $\begin{array}{c}\text { Age at } \\
\text { beginning } \\
\text { of pregnancy } \\
\text { (years) }\end{array}$ & Outcome & $\begin{array}{c}\text { Weeks } \\
\text { pregnancy } \\
\text { lasted } \\
\text { (weeks) }\end{array}$ & $\begin{array}{c}\text { Number of months } \\
\text { breast feeding }\end{array}$ \\
\hline $\begin{array}{l}\text { 2nd } \\
\text { Pregnancy }\end{array}$ & & $\begin{array}{l}\square \text { Single live birth } \\
\square \text { Multiple live } \\
\text { births } \\
\square \text { Stillbirth } \\
\square \text { Miscarriage } \\
\square \text { Abortion }\end{array}$ & & $\begin{array}{l}\square \text { Not applicable } \\
\square \text { Did not breast } \\
\text { feed } \\
\square \text { 1-2 months } \\
\square \text { 3-4 months } \\
\square \text { 5-6 months } \\
\square 7-12 \text { months } \\
\square>12 \text { months }\end{array}$ \\
\hline
\end{tabular}




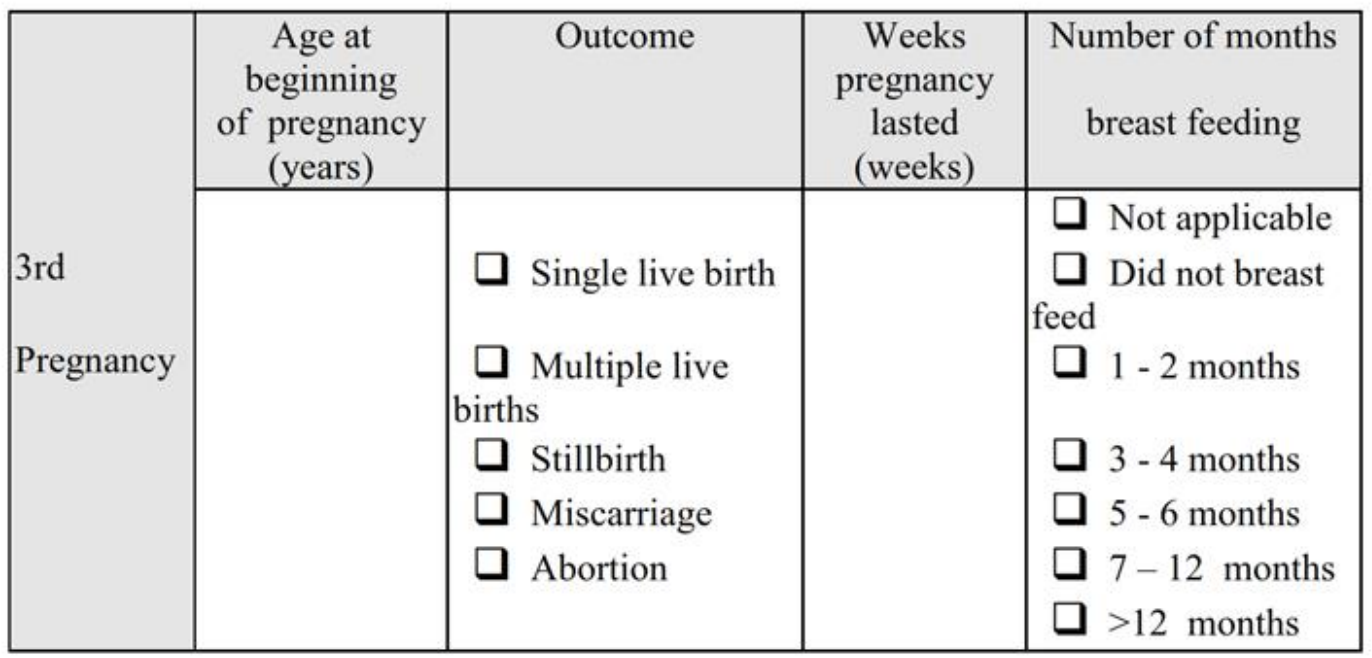

Note: If more than 3 pregnancies, please use an additional page or the blank space on the following page. The interviewer will inquire about more, if applicable. 
The next six questions will be asking about your family members and their history of cancer.

The first five questions (\#26 - \#30) are about your:

- parents

- full brothers

- full sisters

- children.

(A full sibling is one who has both the same mother and father as you.)

The sixth question (\#31) concerns your other relatives and their history of cancer.

Please do not include relatives who joined your family by marriage or adoption.

Please answer the following questions to the best of your knowledge and complete the next 3 pages attached here for all relatives in each of the listed categories - regardless of whether they have or had cancer, they're alive, or you haven't seen or spoken to them for a while.

26. How many full brothers do you have?

27. How many full sisters do you have?

28. How many children do you have?

a. Number of sons?

b. Number of daughters? 


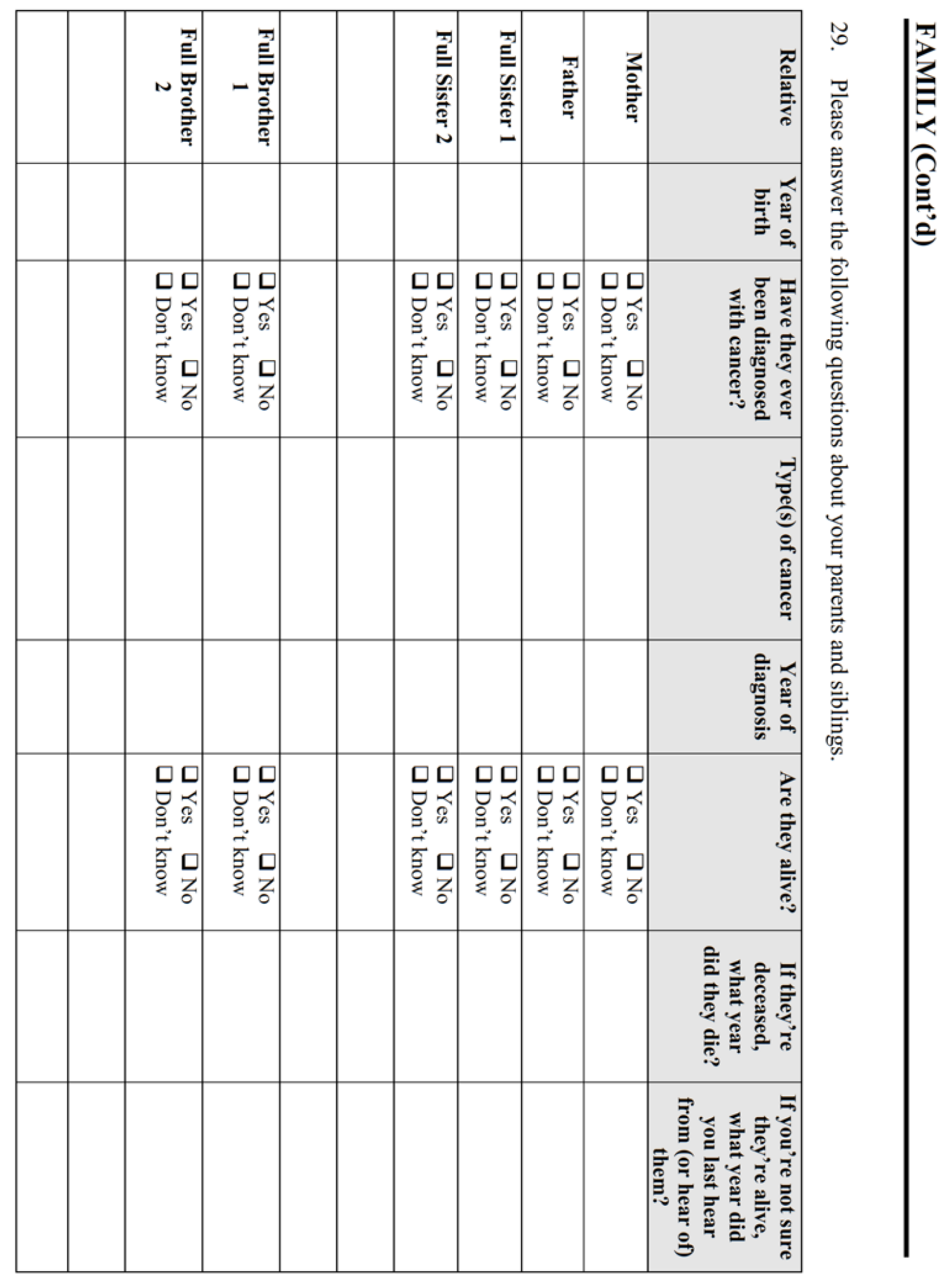




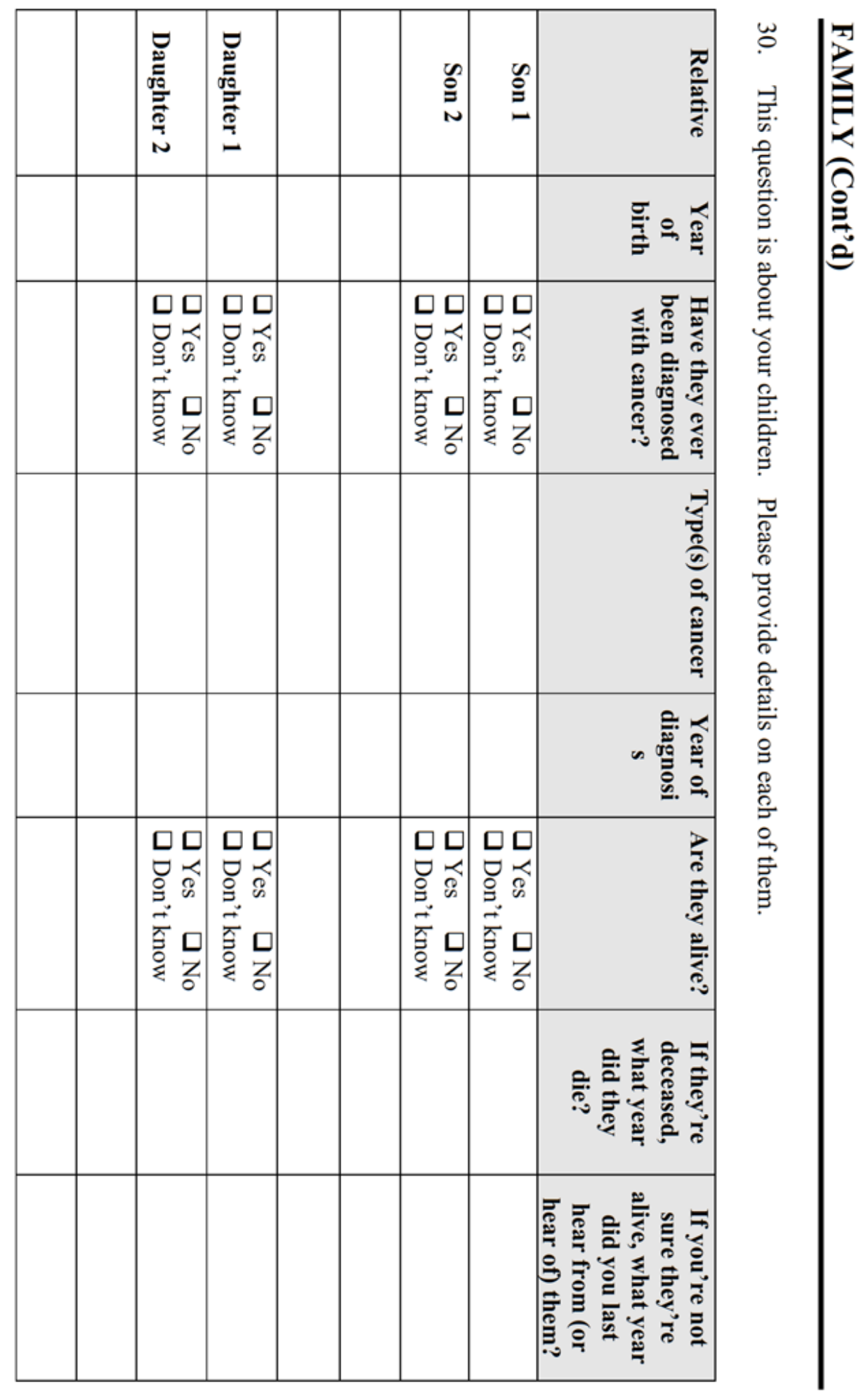




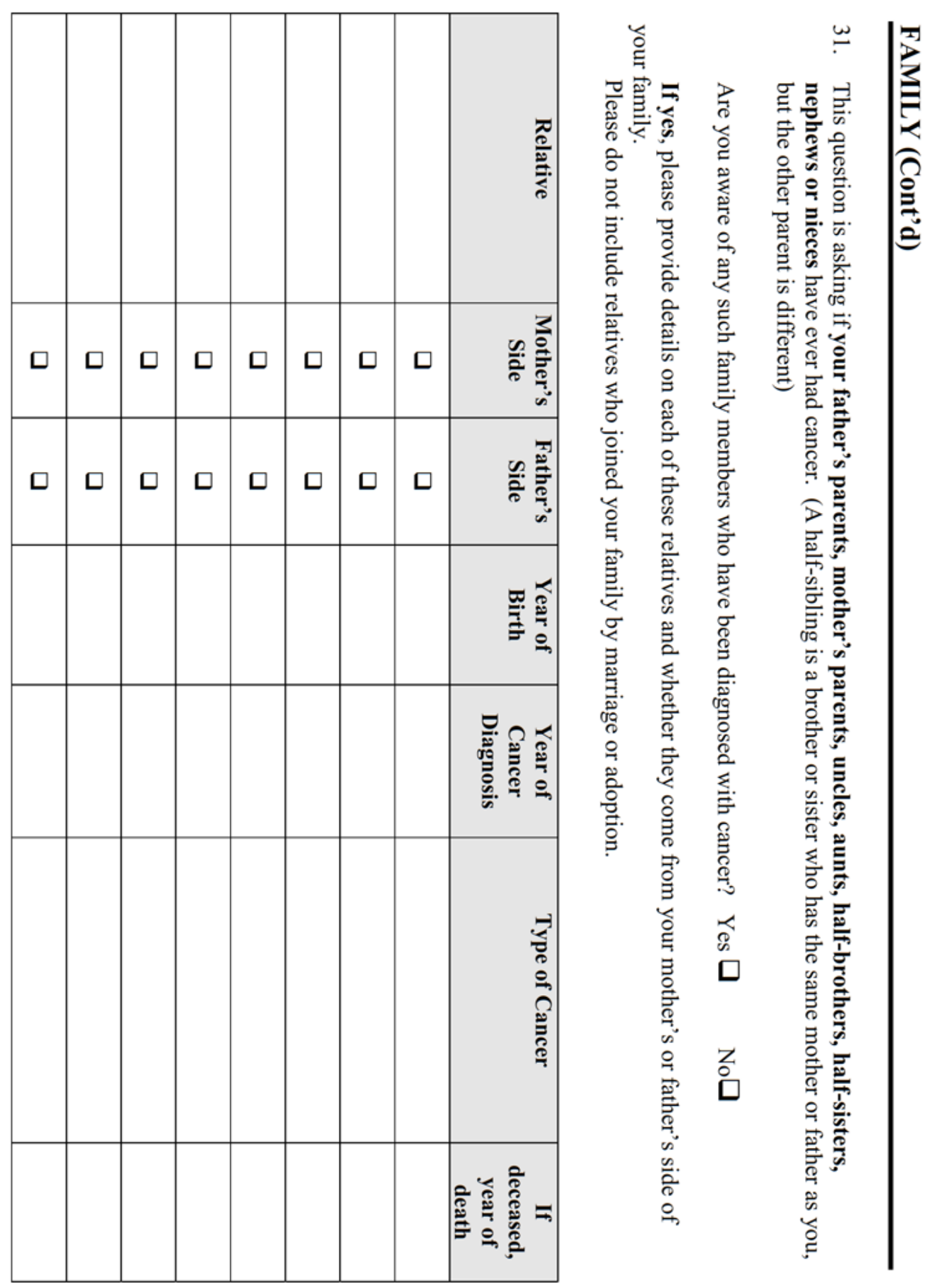




\section{LIFESTYLE HABITS (TOBACCO and ALCOHOL)}

32. Have you ever smoked more than 100 cigarettes in your lifetime?

$\square$ Yes $\square$ No (go to question \#37)

33. How old were you when you STARTED smoking? years of age

34. Are you currently smoking?

Yes $\square$ No - If no, at what age did you quit?

years

35. How many years in total have you smoked cigarettes? (excluding the years that you quit) years

36. For the entire time you smoked, on average, how many cigarettes a day did you usually smoke? cigarettes/day OR cigarettes/week

37. This question asks about your family's smoking habits when you were 19 or younger.

\begin{tabular}{|l|c|c|c|}
\hline FAMILY'S SMOKING HABITS & $\begin{array}{c}\text { FATHER/ } \\
\text { GUARDIAN }\end{array}$ & $\begin{array}{c}\text { MOTHER / } \\
\text { GUARDIAN }\end{array}$ & $\begin{array}{c}\text { OTHER } \\
\text { MEMBER }\end{array}$ \\
\hline $\begin{array}{l}\text { Did your parent(s) or other } \\
\text { household member(s) ever smoke in } \\
\text { your presence when you were 19 or } \\
\text { younger? (go to question \#38 if } \\
\text { "no" for all) }\end{array}$ & $\begin{array}{l}\square \text { Yes } \\
\square \text { No }\end{array}$ & $\begin{array}{l}\square \text { Yes } \\
\square \text { No } \\
\square \text { Yes } \\
\square \text { No }\end{array}$ \\
\hline $\begin{array}{l}\text { For the entire time that s/he smoked, } \\
\text { on average, how many cigarettes a } \\
\text { day did s/he usually smoke? } \\
\text { (cigarettes/day) }\end{array}$ & cigarettes/day & cigarettes/day & $\overline{\text { cigarettes/day }}$ \\
\hline $\begin{array}{l}\text { What age were you when first } \\
\text { exposed to your father's \&/or } \\
\text { mother's tobacco smoke? (years) }\end{array}$ & years old & years old & years old \\
\hline $\begin{array}{l}\text { What age were you when no longer } \\
\text { exposed to your father's \&/or } \\
\text { mother's tobacco smoke? (years) }\end{array}$ & years old & years old & years old \\
\hline
\end{tabular}

38. During this time period (19 or younger), on average, how many hours per week were you exposed to someone else's tobacco smoke?

\begin{tabular}{|l|c|c|c|c|c|c|c|}
\hline & \multicolumn{6}{|c|}{ Hours per week exposed to "second-hand" tobacco smoke } \\
\hline & 0 & $<1$ & $1-2$ & $3-4$ & $5-6$ & $7-9$ & $>9$ \\
\hline $\begin{array}{l}\text { Age: } 19 \text { years and } \\
\text { younger }\end{array}$ & & & & & & & \\
\hline
\end{tabular}




\section{LIFESTYLE HABITS (TOBACCO and ALCOHOL) (Cont'd)}

39. In the past (during different decades of your life), on average, how many hours per week, outside of the workplace, were you exposed to someone else's tobacco smoke?

\begin{tabular}{|c|c|c|c|c|c|c|c|}
\hline & \multicolumn{7}{|c|}{ Hours per week exposed to "second-hand" tobacco smoke } \\
\hline Age (decades) & $\mathbf{0}$ & $<1$ & $1-2$ & 3-4 & 5-6 & $7-9$ & $>9$ \\
\hline 20-29 years & & & & & & & \\
\hline 30-39 years & & & & & & & \\
\hline 40-49 years & & & & & & & \\
\hline $50-59$ years & & & & & & & \\
\hline $\begin{array}{c}2 \text { years ago (if } \\
>60)\end{array}$ & & & & & & & \\
\hline
\end{tabular}

40. This question asks about your alcohol consumption habits.

\begin{tabular}{|c|c|c|c|c|}
\hline & & Beer & Wine & Spirits \\
\hline $\begin{array}{l}\text { Have you ever drank the following more than } \\
\text { twice a year? (if "no" to all } 3 \text {, i.e. beer, wine } \\
\text { and spirits, go to question \#41) }\end{array}$ & $\begin{array}{l}\text { Yes } \\
\text { No }\end{array}$ & $\square$ & $\begin{array}{l}\square \\
\square\end{array}$ & $\begin{array}{l}\square \\
\square\end{array}$ \\
\hline
\end{tabular}

On average, how many drinks per week did you consume during different decades of your life? One drink=1 glass of wine or 1 bottle of beer or 1 oz of spirits

\begin{tabular}{|c|c|c|c|c|}
\hline Teens $(15-19) ?$ & $\begin{array}{c}\text { Drinks/week OR } \\
<1 \text { time/month } \\
\text { Never }\end{array}$ & $\begin{array}{c}\frac{\text { wk }}{\text { per }}^{\square} \\
\square\end{array}$ & $\begin{array}{c}\frac{\text { wk }}{\text { per }} \\
\square \\
\square\end{array}$ & $\begin{array}{c}\frac{\text { wk }}{\text { per }}^{\text {p }} \\
\square\end{array}$ \\
\hline 20-29 years & $\begin{array}{c}\text { Drinks/week OR } \\
<1 \text { time/month } \\
\text { Never }\end{array}$ & $\begin{array}{c}\frac{\text { wk }}{\text { per }}^{\square} \\
\square\end{array}$ & $\begin{array}{c}\frac{\text { wk }}{\text { per }}^{\square} \\
\square \\
\end{array}$ & $\begin{array}{c}\frac{\text { wk }}{\text { pk }}^{\text {per }} \\
\square \\
\square\end{array}$ \\
\hline 30-39 years & $\begin{array}{c}\text { Drinks/week OR } \\
<1 \text { time/month } \\
\text { Never }\end{array}$ & $\begin{array}{c}\frac{\text { wk }}{\text { per }}^{\square} \\
\square\end{array}$ & $\begin{array}{c}\frac{\text { wk }}{\text { per }}^{\square} \\
\square \\
\end{array}$ & $\begin{array}{c}\frac{\text { wk }}{\text { per }}^{\text {p }} \\
\square\end{array}$ \\
\hline 40-49 years & $\begin{array}{c}\text { Drinks/week OR } \\
<1 \text { time/month } \\
\text { Never }\end{array}$ & $\begin{array}{c}\frac{\text { wk }}{\text { per }}^{\square} \\
\square\end{array}$ & $\begin{array}{c}\frac{\text { wk }}{\text { per }} \\
\square \\
\square\end{array}$ & $\begin{array}{c}\frac{\text { wk }}{\text { wk }}^{\text {per }} \\
\square \\
\square\end{array}$ \\
\hline $50-59$ years & $\begin{array}{l}\text { Drinks/week OR } \\
<1 \text { time/month }\end{array}$ & $\frac{\mathrm{wk}}{\mathrm{wk}}^{\mathrm{per}}$ & $\frac{\mathrm{wk}}{\mathrm{per}}^{\mathrm{p}}$ & ${\underset{\mathrm{wk}}{\mathrm{per}}}^{\mathrm{p}}$ \\
\hline
\end{tabular}




\begin{tabular}{|l|c|c|c|c|}
\hline & Never & $\square$ & $\square$ & $\square$ \\
\hline 2 years ago (if over 60 years of age) & $\begin{array}{c}\text { Drinks/week OR } \\
<1 \text { time/month }\end{array}$ & $\begin{array}{c}\text { wk } \\
\text { wer }\end{array}$ & $\begin{array}{c}\text { wk per } \\
\text { wk }\end{array}$ & $\begin{array}{l}\text { per } \\
\text { wk } \\
\square\end{array}$ \\
\hline
\end{tabular}




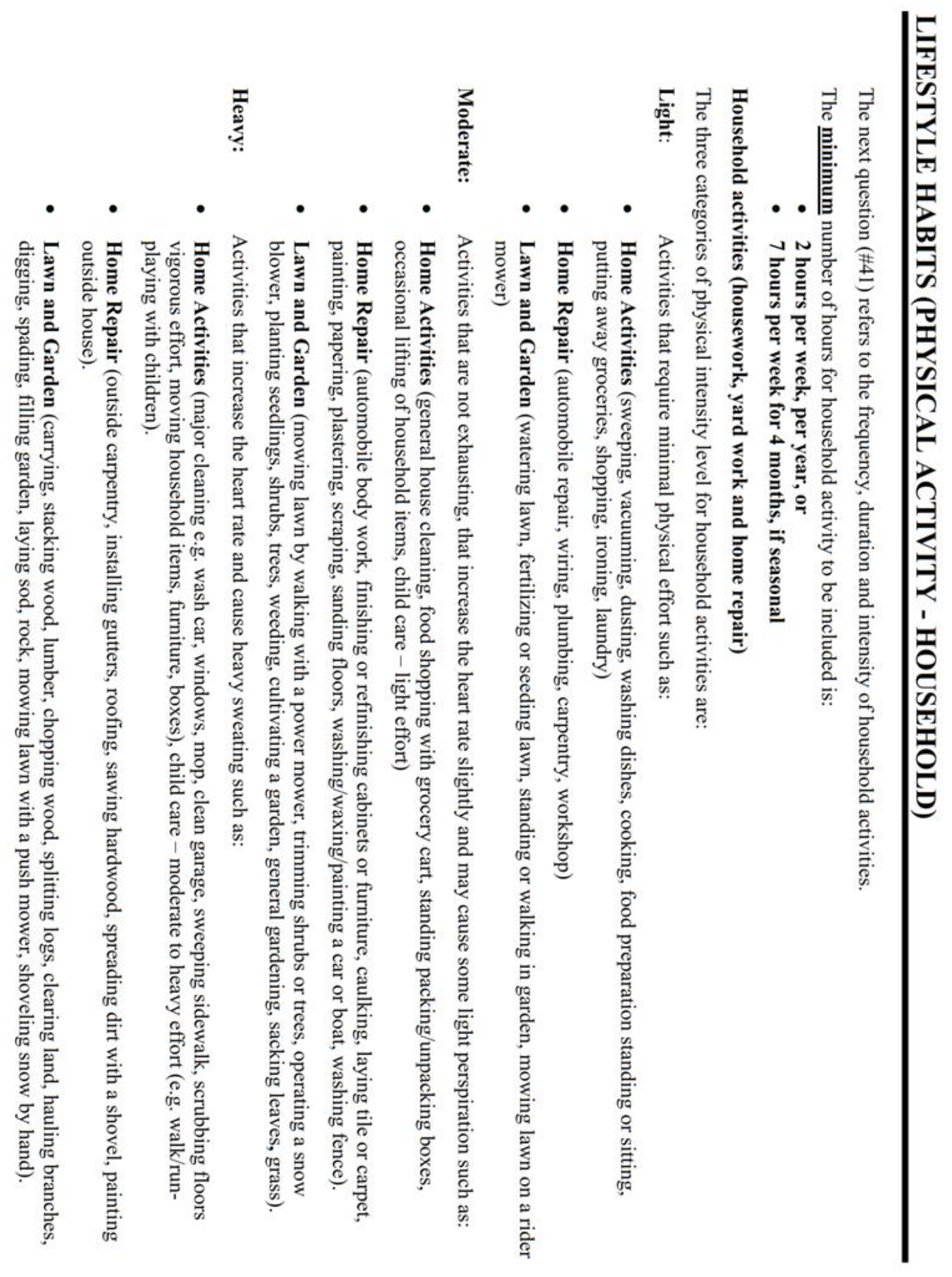




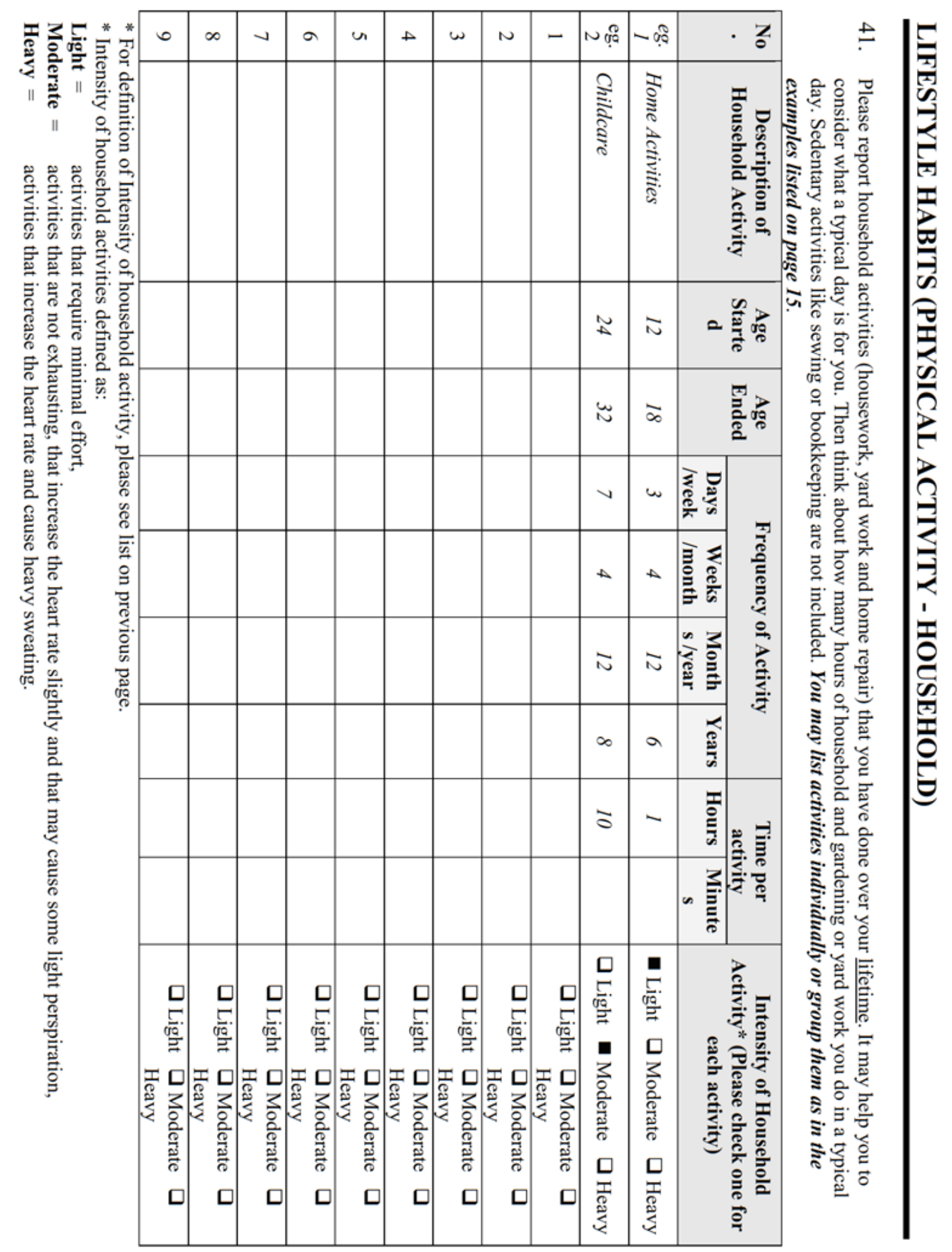




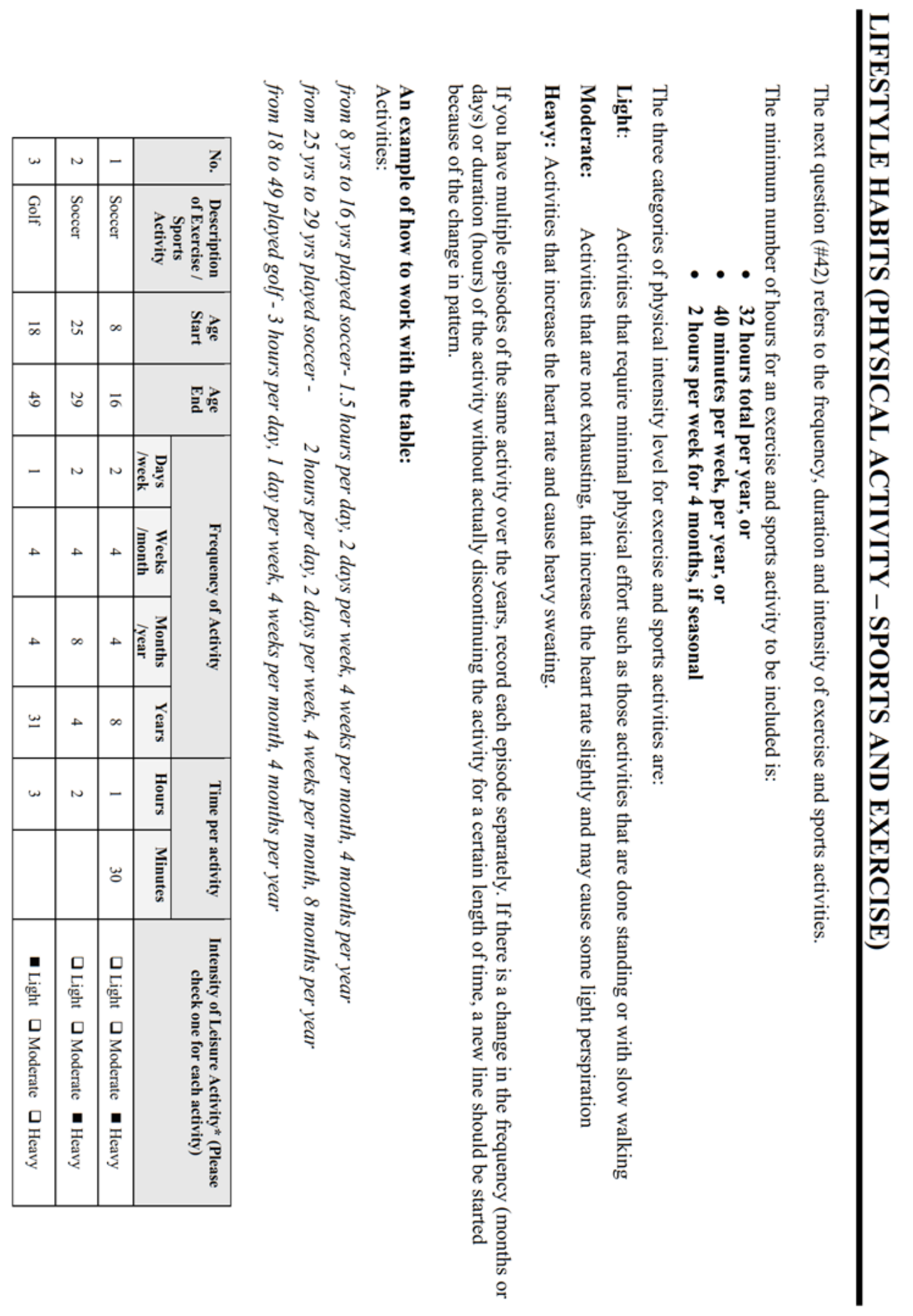




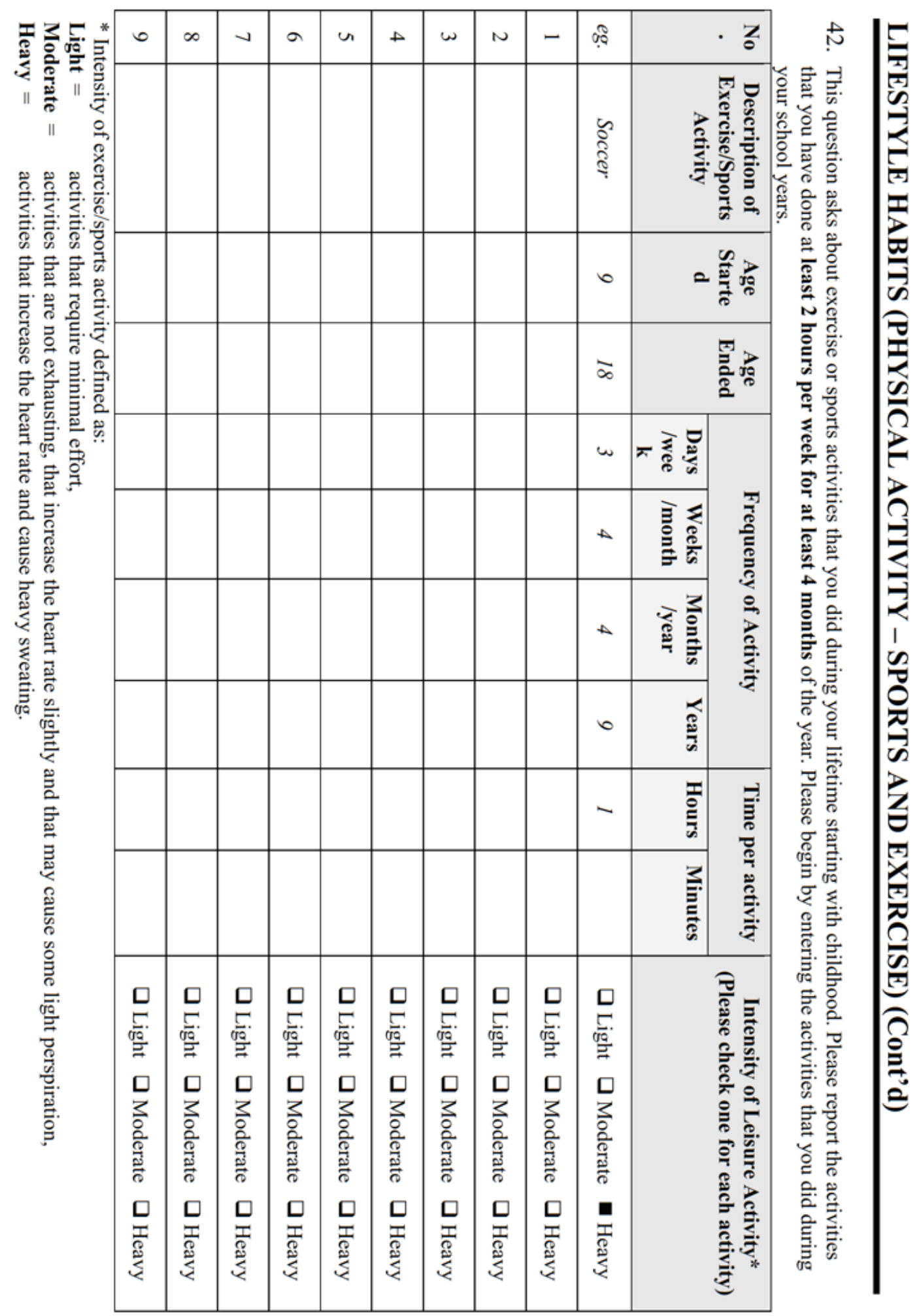




\section{LIFESTYLE HABITS (SMOKED/GRILLED FOODS)}

43. During different decades of your life, how often did you usually eat meat or fish that had been smoked or that had a strong smoky taste?

\begin{tabular}{|c|c|c|c|c|}
\hline $\begin{array}{l}\text { Age } \\
\text { (decad } \\
\text { es) }\end{array}$ & $\begin{array}{c}\text { Times/week } \\
\text { OR }\end{array}$ & $\begin{array}{c}\text { Times/month } \\
\text { OR }\end{array}$ & Times/year OR & $\begin{array}{c}\text { Never/Almost } \\
\text { never }\end{array}$ \\
\hline $\begin{array}{c}\text { Teen's (12- } \\
19)\end{array}$ & & & & $\square$ \\
\hline 20-29 years & & & & $\square$ \\
\hline $30-39$ years & & & & 口 \\
\hline 40-49 years & & & & $\square$ \\
\hline 50-59 years & & & & $\square$ \\
\hline 2 years ago & & & & $\square$ \\
\hline
\end{tabular}

44. During different decades of your life, how often did you usually eat pickles or other pickled foods?

\begin{tabular}{|l|c|c|c|c|}
\hline $\begin{array}{c}\text { Age } \\
\text { (decad } \\
\text { es) }\end{array}$ & $\begin{array}{c}\text { Times/week } \\
\text { OR }\end{array}$ & $\begin{array}{r}\text { Times/month } \\
\text { OR } \\
\text { 19) }\end{array}$ & $\begin{array}{c}\text { Times/year OR } \\
\text { Teen's (12- }\end{array}$ & $\begin{array}{c}\text { Never/Almost } \\
\text { never }\end{array}$ \\
\hline $\begin{array}{c}\text { 20-29 years } \\
\text { 30-39 years }\end{array}$ & & & $\square$ \\
\hline 40-49 years & & & & $\square$ \\
\hline 50-59 years & & & & $\square$ \\
\hline 2 years ago & & & & $\square$ \\
\hline
\end{tabular}

45. During different decades of your life, how often did you usually eat charcoal-grilled foods in the summer?

\begin{tabular}{|l|c|c|c|c|}
\hline $\begin{array}{c}\text { Age } \\
\text { (decad } \\
\text { es) }\end{array}$ & $\begin{array}{r}\text { Times/week } \\
\text { OR }\end{array}$ & $\begin{array}{r}\text { Times/month } \\
\text { OR } \\
\text { 19) }\end{array}$ & & $\begin{array}{c}\text { Times/year OR } \\
\text { Never/Almost } \\
\text { never }\end{array}$ \\
\hline $\begin{array}{c}\text { Teen's (12- } \\
\text { 20-29 years }\end{array}$ & & & $\square$ \\
\hline 30-39 years & & & & $\square$ \\
\hline 40-49 years & & & & $\square$ \\
\hline 50-59 years & & & & $\square$ \\
\hline 2 years ago & & & $\square$ \\
\hline
\end{tabular}


46. During different decades of your life, how often did you usually eat charcoal-grilled foods in the winter?

\begin{tabular}{|l|c|c|c|c|}
\hline $\begin{array}{l}\text { Age } \\
\text { (decades) }\end{array}$ & $\begin{array}{c}\text { Times/week } \\
\text { OR }\end{array}$ & $\begin{array}{c}\text { Times/month } \\
\text { OR }\end{array}$ & $\begin{array}{c}\text { Times/year } \\
\text { OR }\end{array}$ & $\begin{array}{c}\text { Never/Almost } \\
\text { never }\end{array}$ \\
\hline $\begin{array}{l}\text { Teen's (12- } \\
\text { 19) }\end{array}$ & & & & $\square$ \\
\hline 20-29 years & & & & $\square$ \\
\hline 30-39 years & & & & $\square$ \\
\hline 40-49 years & & & & $\square$ \\
\hline 50-59 years & & & & $\square$ \\
\hline 2 years ago & & & & $\square$ \\
\hline
\end{tabular}




\section{Congratulations!!}

You are over halfway there!!

The next portion of the questionnaire relates to residential and occupational history. Please take a moment to stretch your legs and pour a cup of tea if you wish before beginning this section.

... and please also remember that by completing this questionnaire you are contributing to very important research and your generous gift of time is very much appreciated! 


\begin{tabular}{|c|c|c|c|c|c|}
\hline$\dddot{y}$ & 声 & $\breve{z}$ & $\tilde{z}$ & $\bar{n}$ & \\
\hline 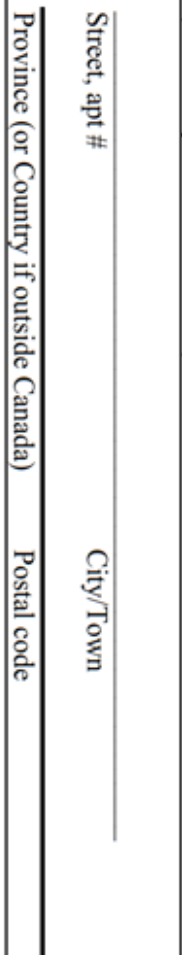 & 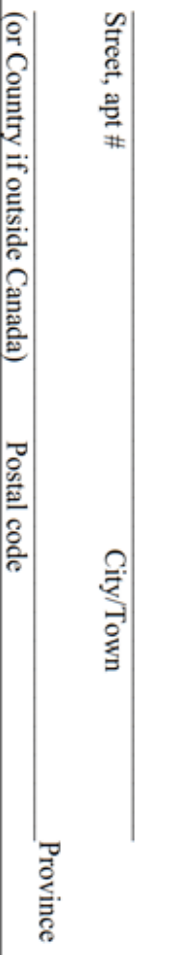 & 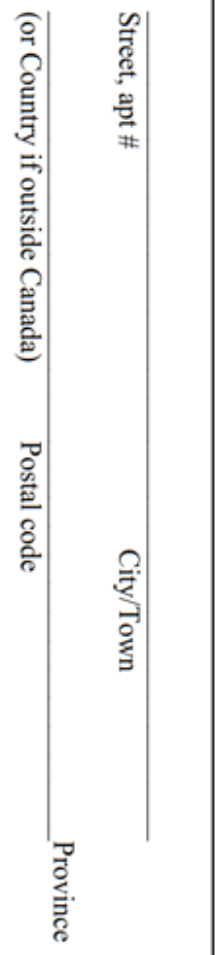 & 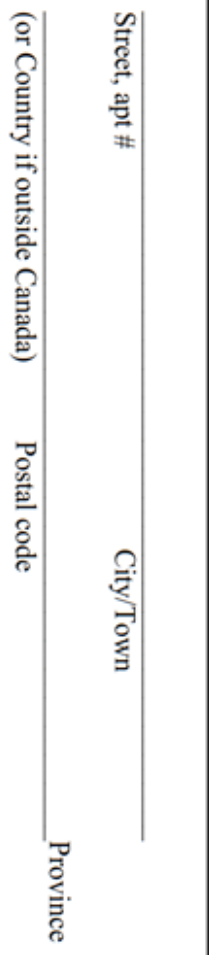 & 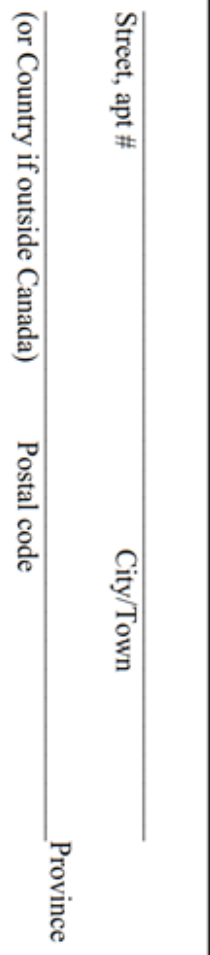 & 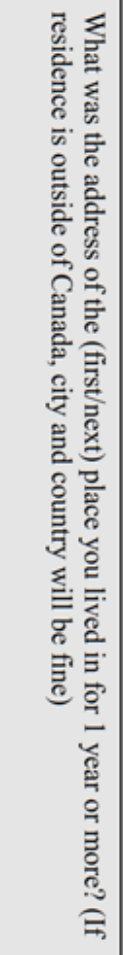 \\
\hline ש & 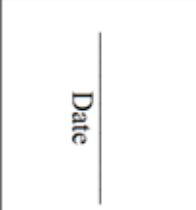 & 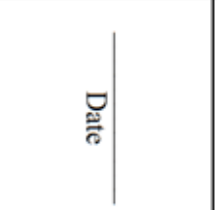 & 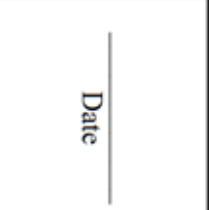 & $\begin{array}{l}\text { 맬 } \\
\text { है }\end{array}$ & 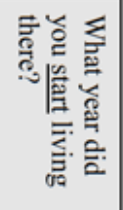 \\
\hline 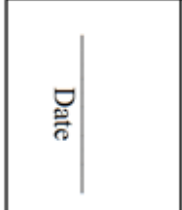 & $\begin{array}{l}\text { 류 } \\
\text { है }\end{array}$ & 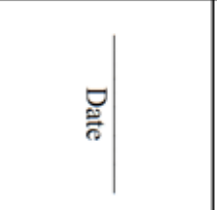 & $\begin{array}{l}\mathbb{U} \\
\text { है }\end{array}$ & $\begin{array}{l}\text { 률 } \\
\text { है }\end{array}$ & 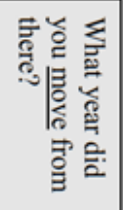 \\
\hline & & 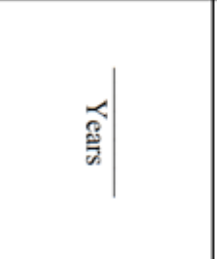 & 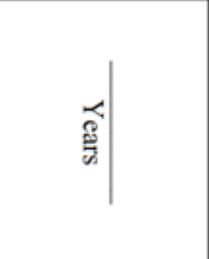 & 蔍 & 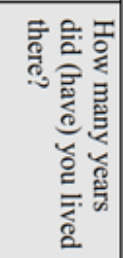 \\
\hline 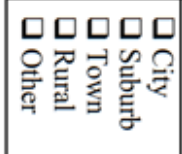 & 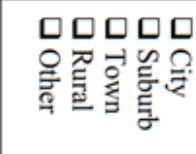 & 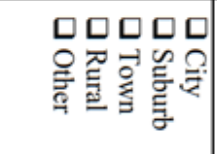 & 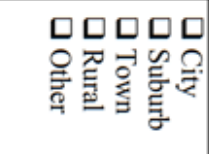 & 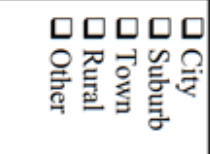 & 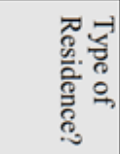 \\
\hline
\end{tabular}

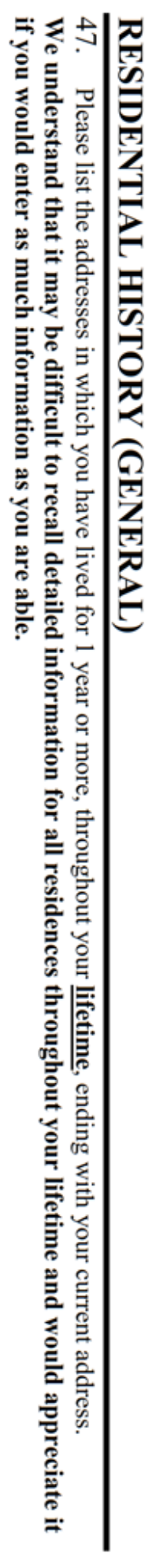




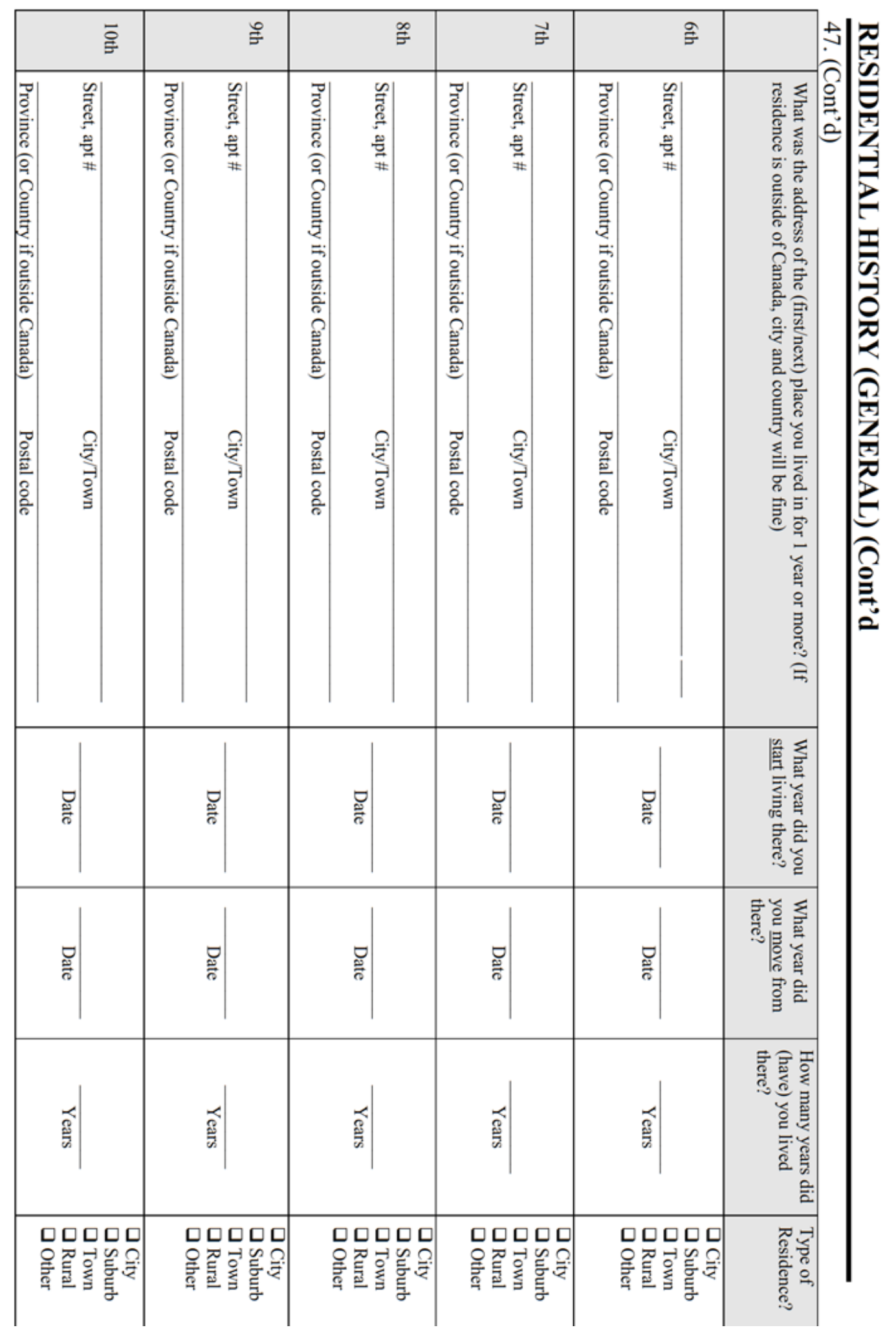




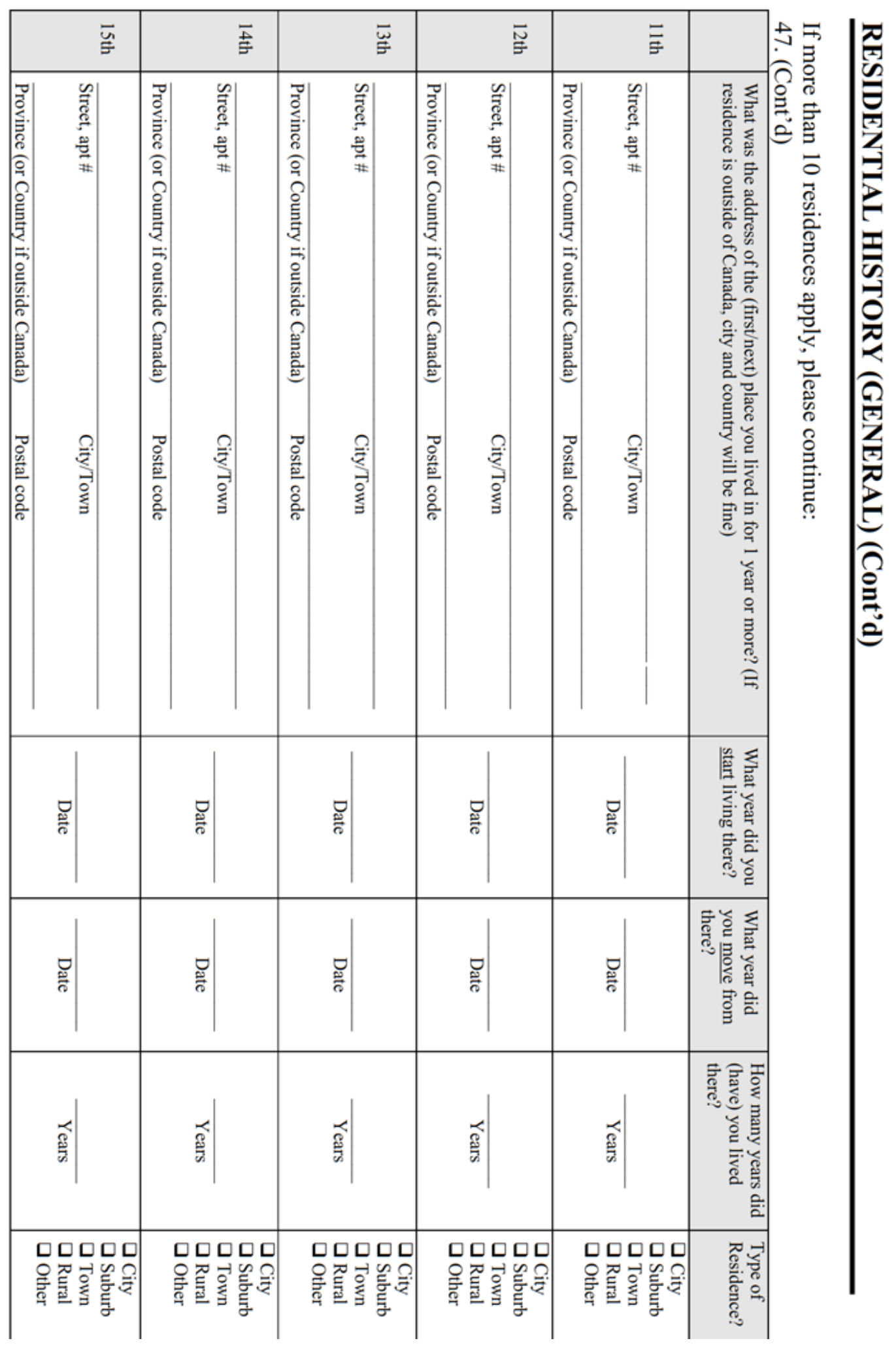




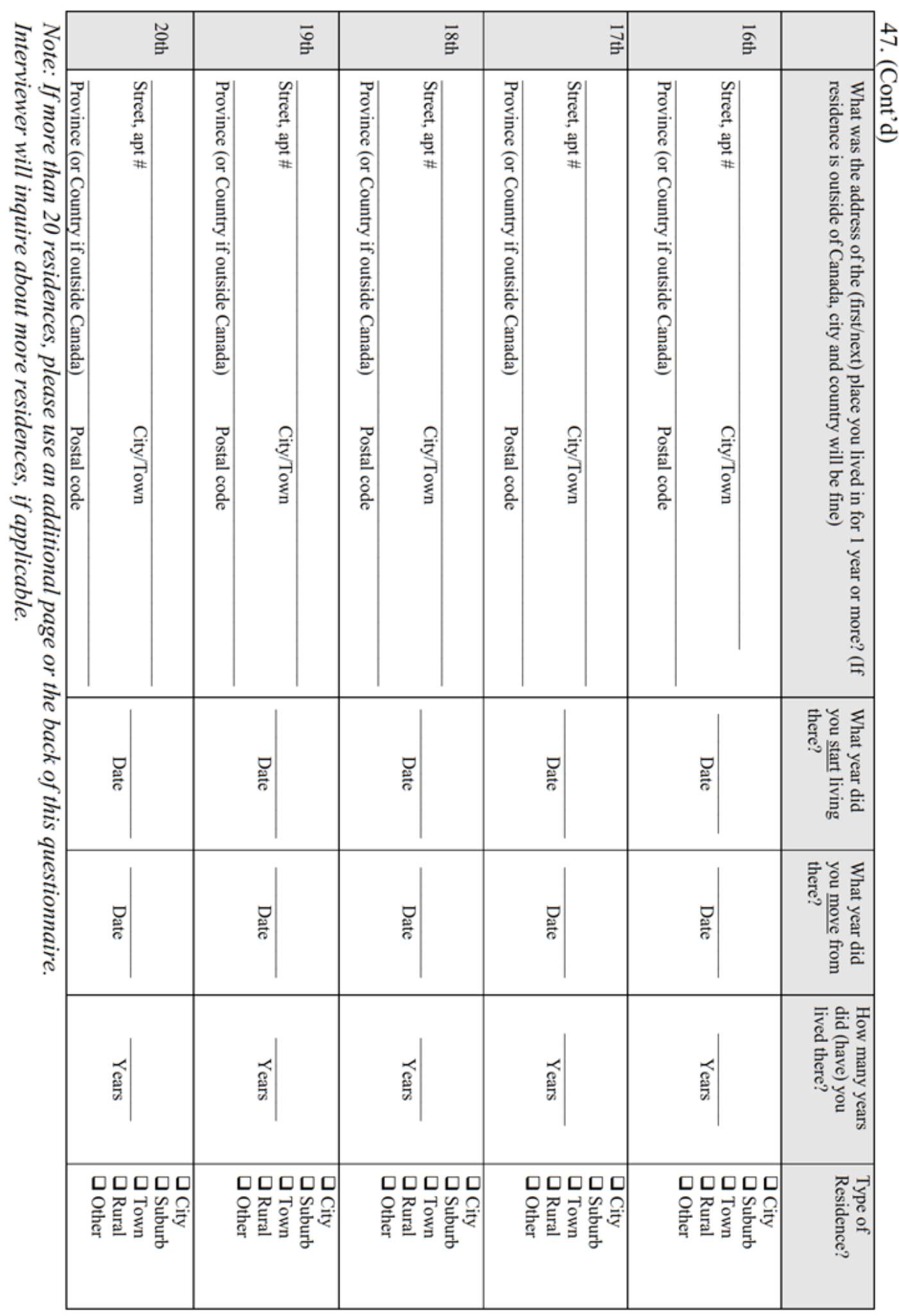




\begin{tabular}{|c|c|c|c|c|c|c|c|c|c|c|c|c|c|c|c|c|c|c|c|}
\hline & & & & $\theta$ & & & & 0 & & & & & & $\boldsymbol{\nabla}$ & \multicolumn{4}{|r|}{$>$} & \\
\hline \multicolumn{5}{|c|}{ 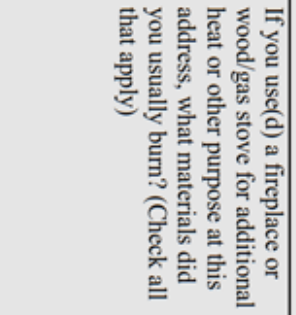 } & \multicolumn{4}{|c|}{ 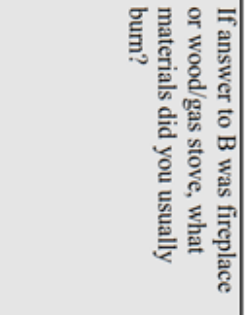 } & \multicolumn{6}{|c|}{ 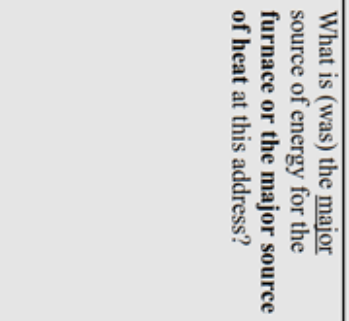 } & \multicolumn{4}{|c|}{ 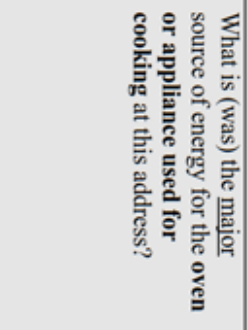 } & \\
\hline 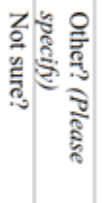 & 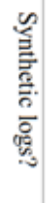 & 胥 & 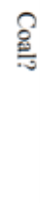 & $\begin{array}{l}\vdots \\
\vdots \\
\vdots \\
\vdots\end{array}$ & 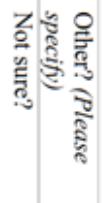 & 奥 & 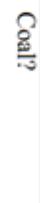 & 京 & 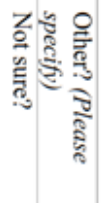 & 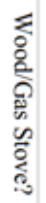 & 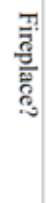 & 옳 & 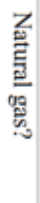 & $\begin{array}{l}\frac{\square}{8} \\
\frac{7}{7} \\
\overline{ } \\
\overline{:}\end{array}$ & 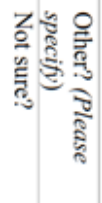 & 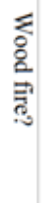 & 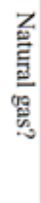 & 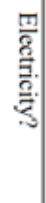 & \\
\hline & & & & & & & & & & & & & & & & & & & $\begin{array}{l}\bar{n} \\
\vec{\pi} \\
\vec{n}\end{array}$ \\
\hline & & & & & & & & & & & & & & & & & & & $\frac{\sqrt{\tilde{Z}}}{\mathbb{2}}$ \\
\hline & & & & & & & & & & & & & & & & & & & 怨 \\
\hline & & & & & & & & & & & & & & & & & & & $\overrightarrow{\vec{\sigma}}$ \\
\hline & & & & & & & & & & & & & & & & & & & 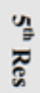 \\
\hline & & & & & & & & & & & & & & & & & & & $\stackrel{\vec{\Xi}}{\overrightarrow{\widetilde{B}}}$ \\
\hline & & & & & & & & & & & & & & & & & & & $\frac{\vec{\Xi}}{\overrightarrow{\widetilde{Z}}}$ \\
\hline & & & & & & & & & & & & & & & & & & & $\underset{\mathbb{R}}{\stackrel{\infty}{\vec{Z}}}$ \\
\hline & & & & & & & & & & & & & & & & & & & 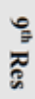 \\
\hline & & & & & & & & & & & & & & & & & & & $\begin{array}{l}\bar{E} \\
\vec{Z} \\
\vec{Z}\end{array}$ \\
\hline
\end{tabular}

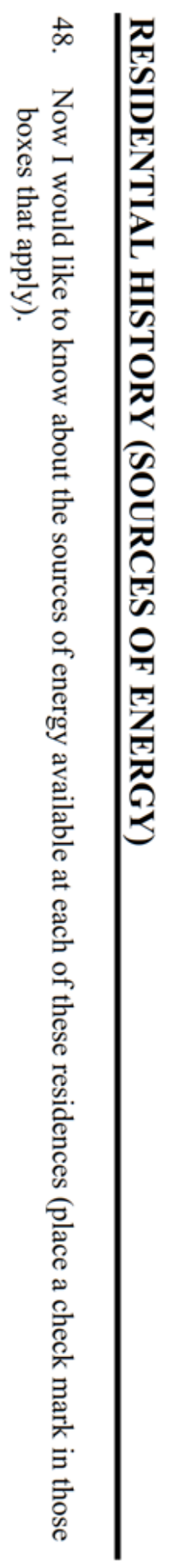




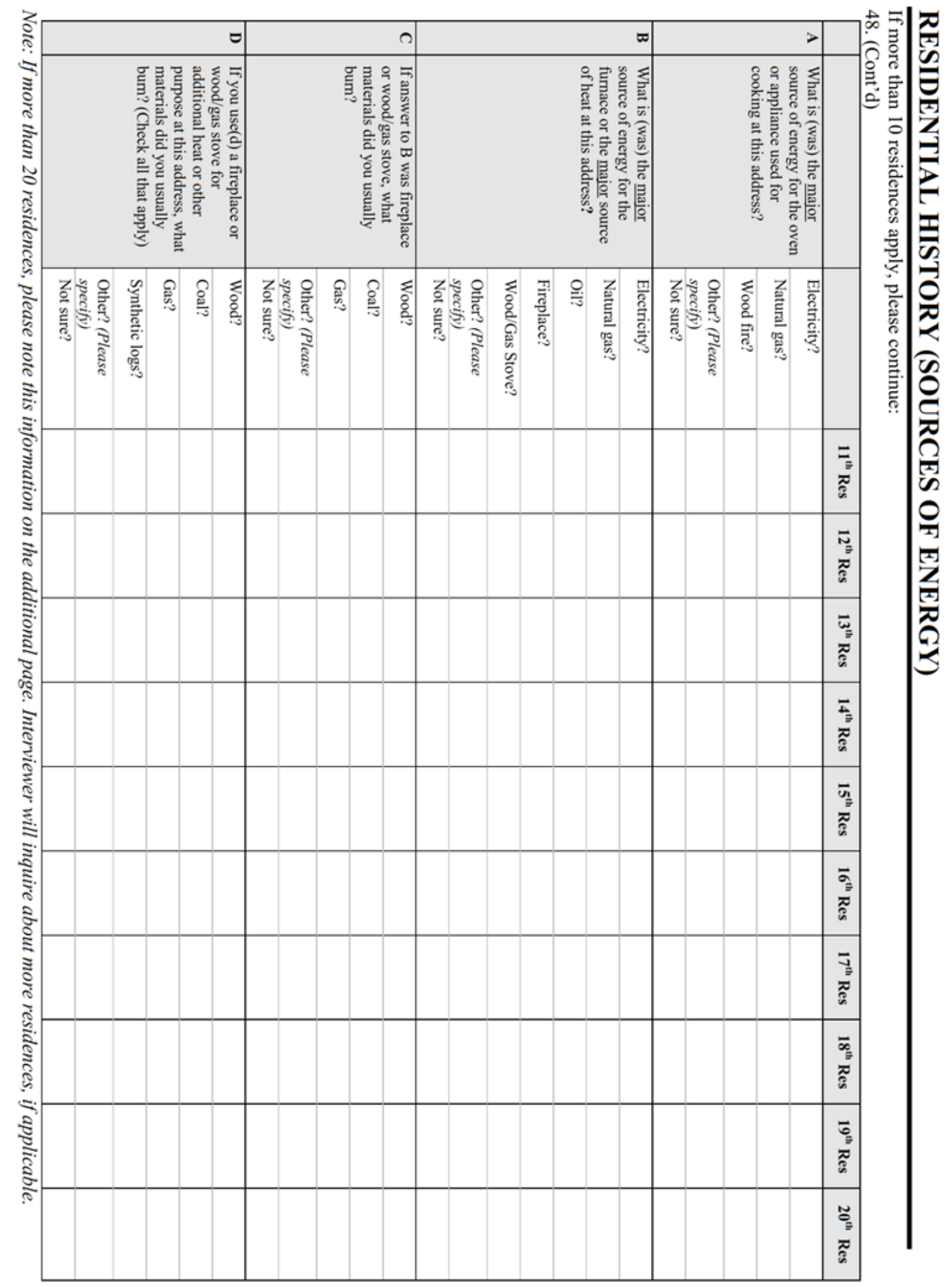




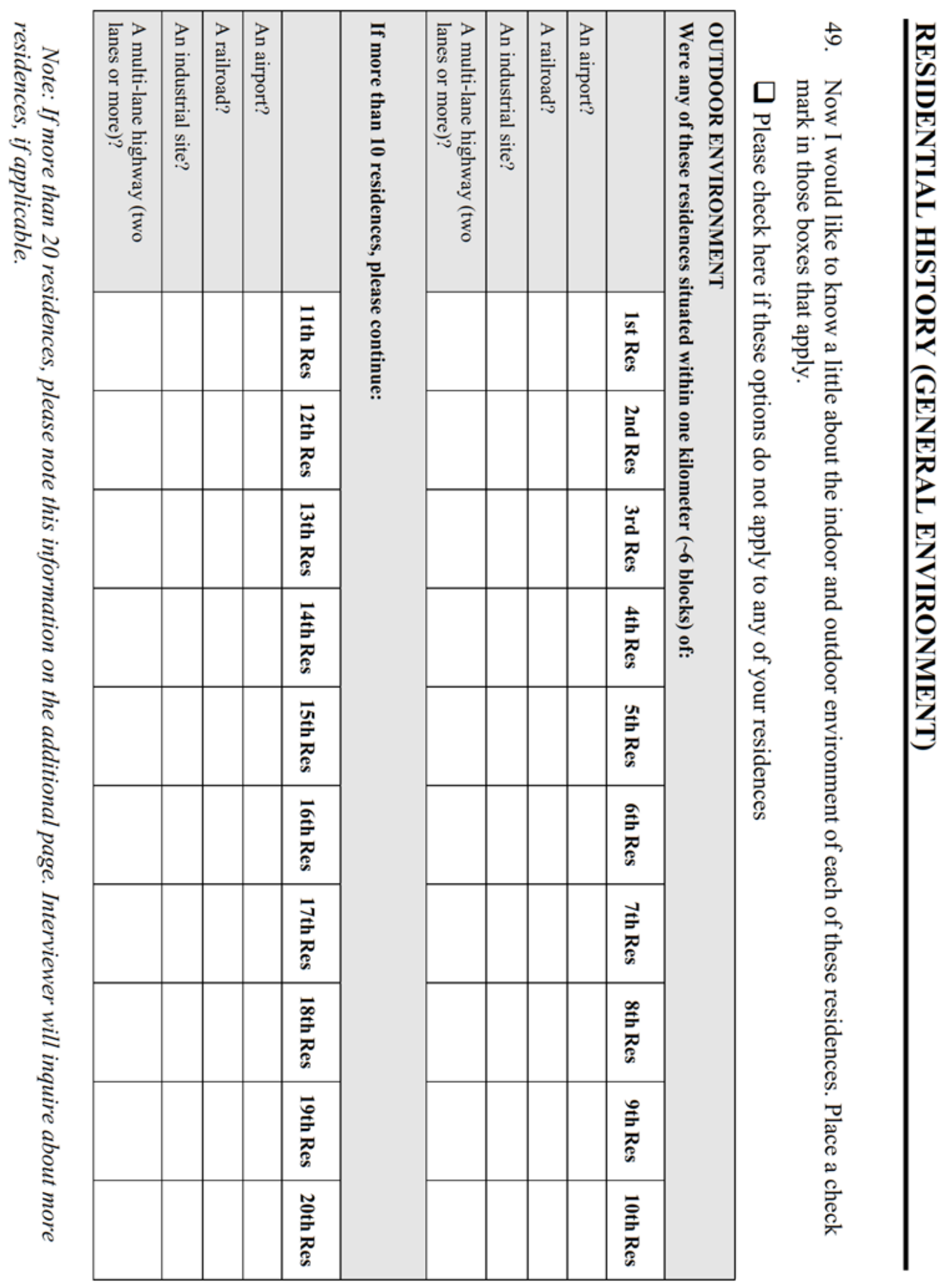




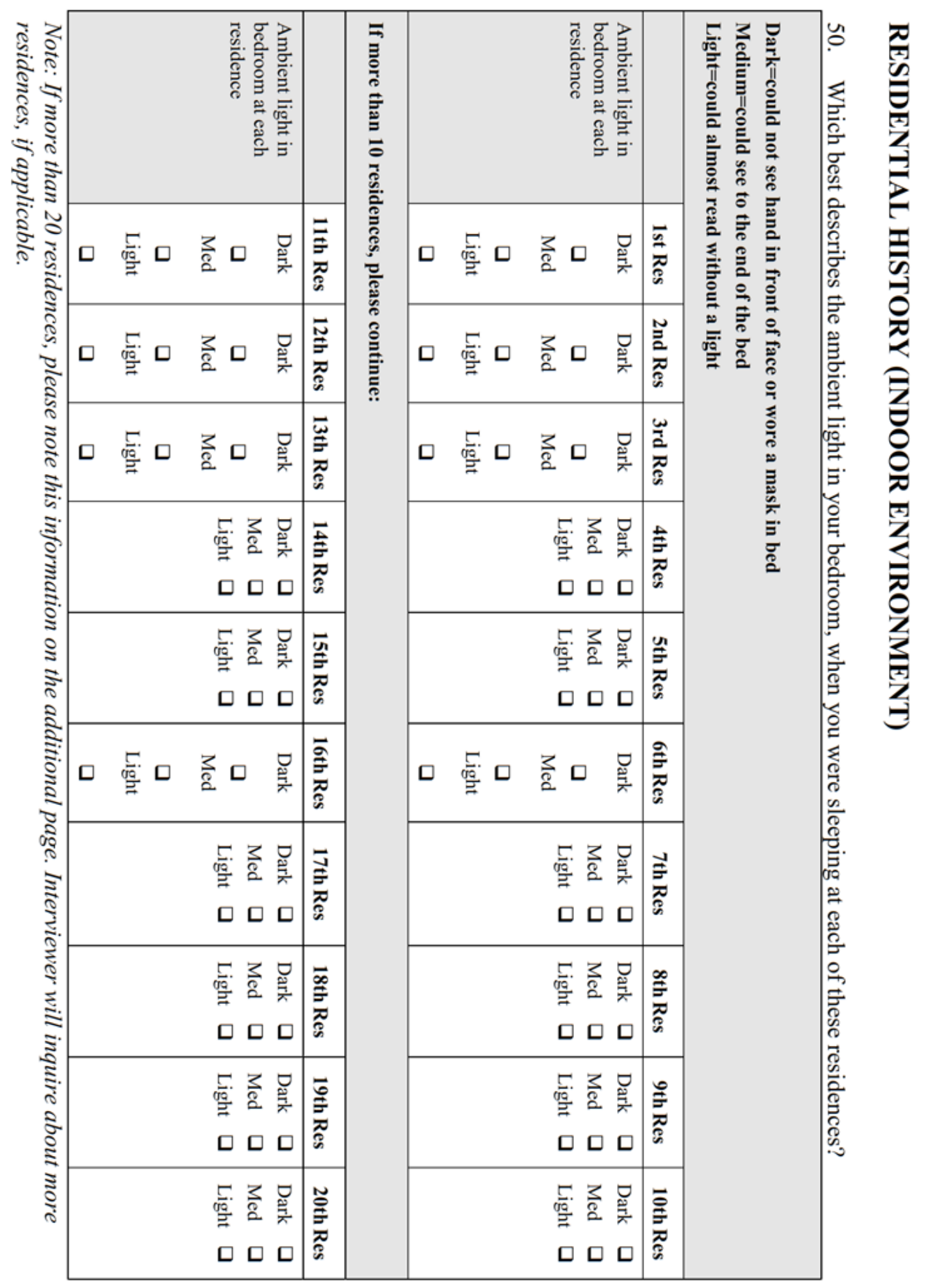




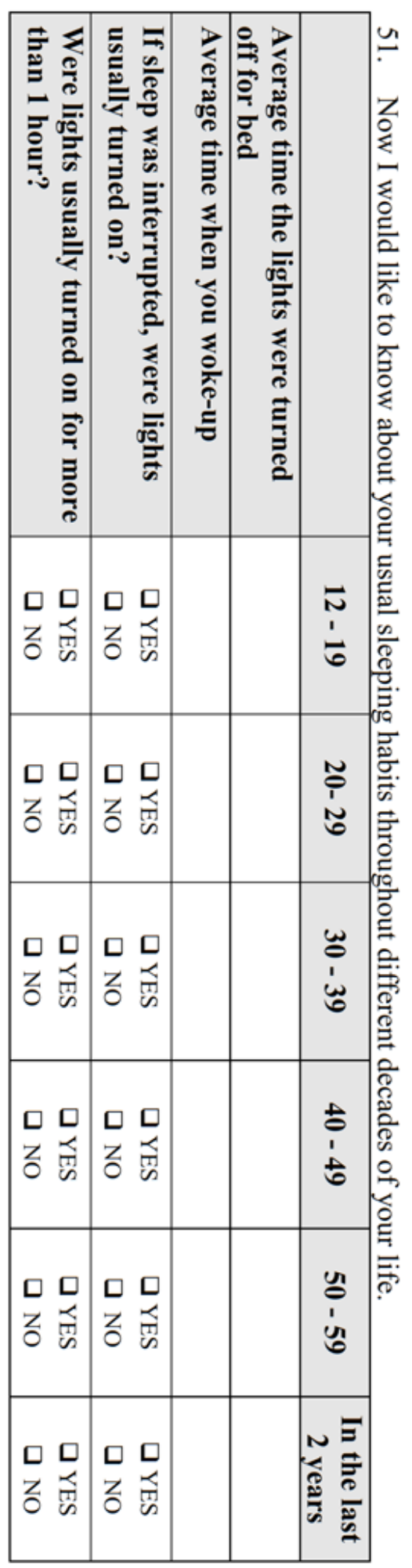




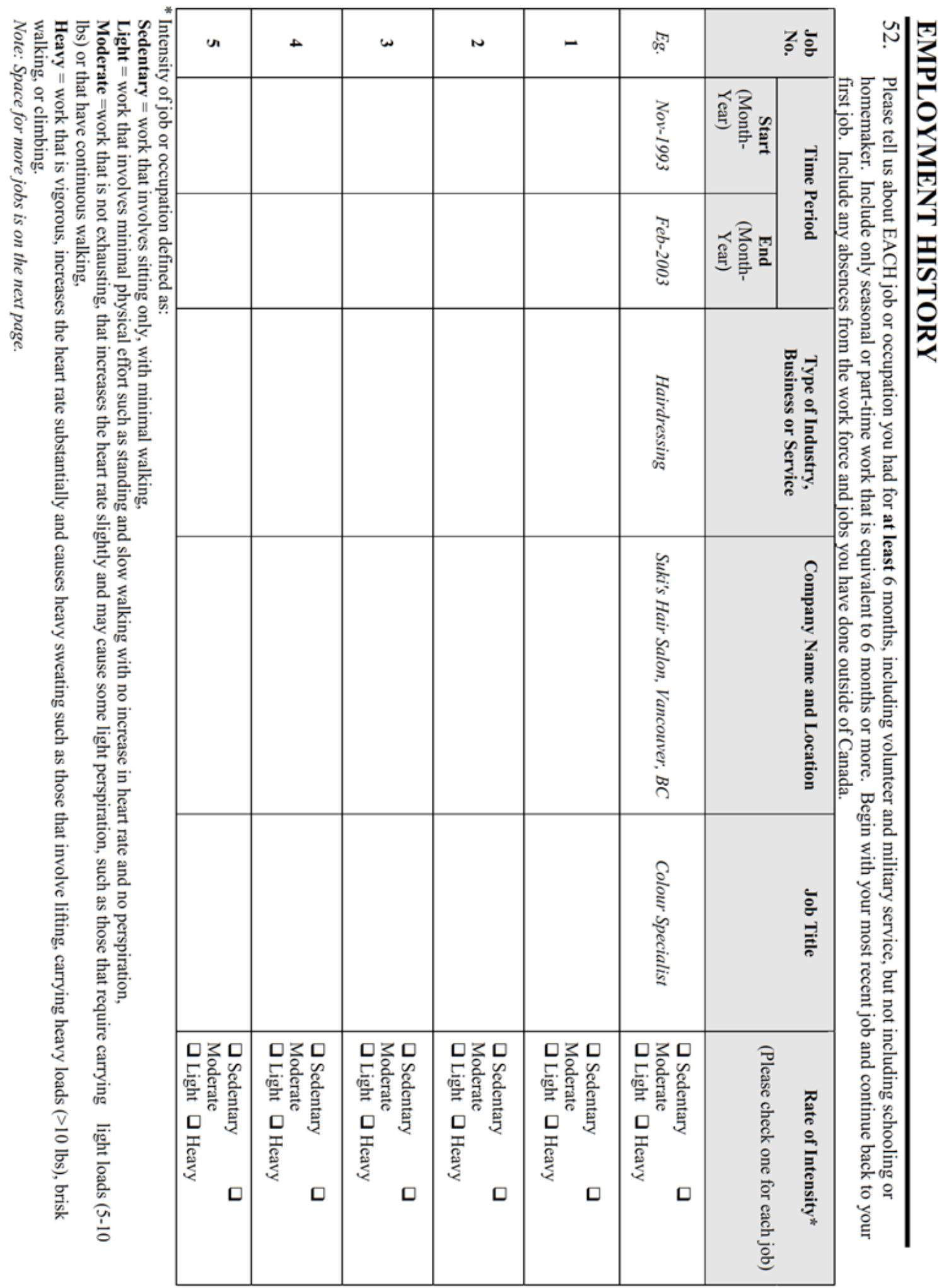




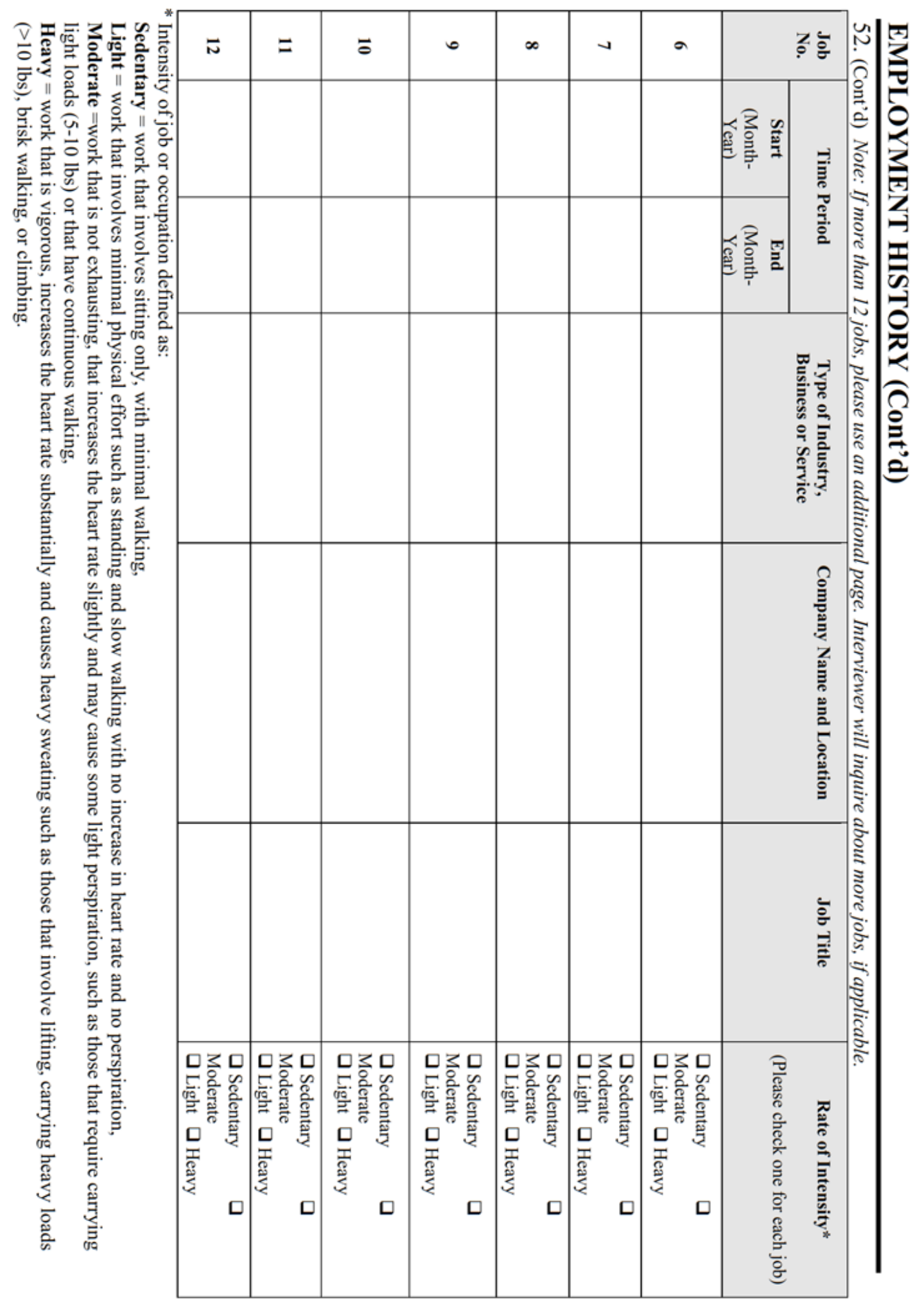




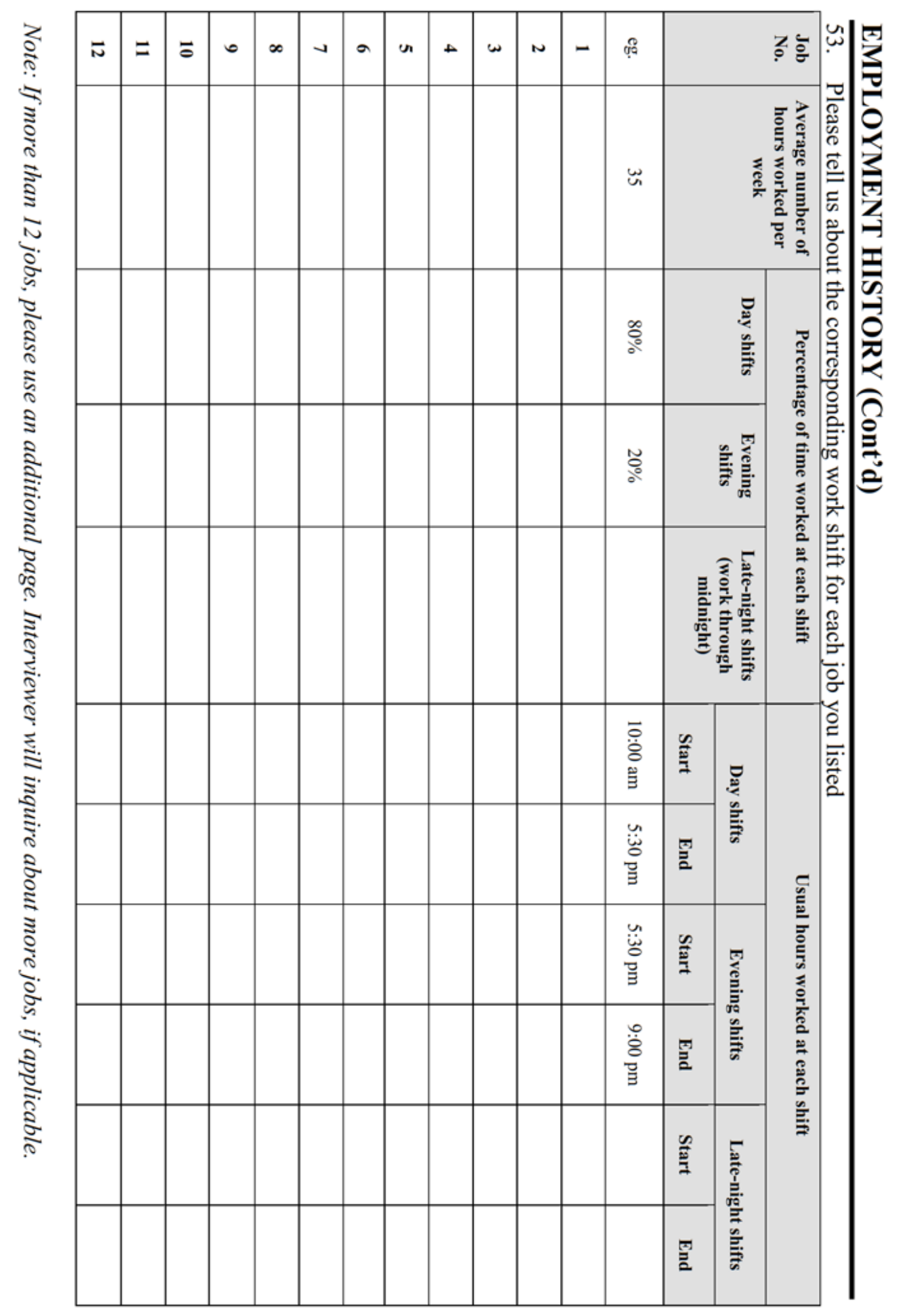




\section{EMPLOYMENT HISTORY (Cont'd)}

54. Please tell us about the corresponding exposures to passive smoking and engine exhausts for each job you listed. In addition, could you tell us the mode of transport used to commute to each job listed

\begin{tabular}{|c|c|c|c|c|c|}
\hline $\begin{array}{l}\text { Job } \\
\text { No. }\end{array}$ & $\begin{array}{l}\text { At this job, on } \\
\text { average, about } \\
\text { how many people } \\
\text { around you } \\
\text { smoked? }\end{array}$ & $\begin{array}{l}\text { While on this job, } \\
\text { did you ever work } \\
\text { near diesel engines } \\
\text { or other types of } \\
\text { engines? }\end{array}$ & $\begin{array}{l}\text { While on this job, } \\
\text { did you ever smell } \\
\text { diesel exhaust or } \\
\text { other types of engine } \\
\text { exhaust? }\end{array}$ & $\begin{array}{l}\text { How did you usually comn } \\
\text { job? }\end{array}$ & nute to this \\
\hline 1 & $\begin{array}{l}\square 0 \text { smokers } \\
\square<10 \\
\square 11-19 \\
\square 20 \text { or more } \\
\square \text { Not sure }\end{array}$ & $\begin{array}{l}\square \text { Yes } \\
\square \text { No } \\
\square \text { Not sure }\end{array}$ & $\begin{array}{l}\square \text { Yes } \\
\text { No } \\
\square \text { Not sure }\end{array}$ & $\begin{array}{l}\square \text { Bus/Tramway } \\
\square \text { Metro/Train } \\
\square \text { Car } \\
\square \text { Bicycle } \square \text { No Commute } \\
\square \text { Motorcycle }\end{array}$ & $\begin{array}{l}\square \text { Foot } \\
\square \text { Other } \\
\square \text { Truck } \\
\square \text { Not sure }\end{array}$ \\
\hline 2 & $\begin{array}{l}\square 0 \text { smokers } \\
\square<10 \\
\square 11-19 \\
\square 20 \text { or more } \\
\square \text { Not sure }\end{array}$ & $\begin{array}{l}\square \text { Yes } \\
\square \text { No } \\
\square \text { Not sure }\end{array}$ & $\begin{array}{l}\square \text { Yes } \\
\text { No } \\
\square \text { Not sure }\end{array}$ & $\begin{array}{l}\square \text { Bus/Tramway } \\
\square \text { Metro/Train } \\
\square \text { Car } \\
\square \text { Bicycle } \square \text { No Commute } \\
\square \text { Motorcycle }\end{array}$ & $\begin{array}{l}\square \text { Foot } \\
\square \text { Other } \\
\square \text { Truck } \\
\square \text { Not sure }\end{array}$ \\
\hline 3 & $\begin{array}{l}\square 0 \text { smokers } \\
\square<10 \\
\square 11-19 \\
\square 20 \text { or more } \\
\square \text { Not sure }\end{array}$ & $\begin{array}{l}\square \text { Yes } \\
\square \text { No } \\
\square \text { Not sure }\end{array}$ & $\begin{array}{l}\square \text { Yes } \\
\square \text { No } \\
\square \text { Not sure }\end{array}$ & $\begin{array}{l}\square \text { Bus/Tramway } \\
\square \text { Metro/Train } \\
\square \text { Car } \\
\square \text { Bicycle } \square \text { No Commute } \\
\square \text { Motorcycle }\end{array}$ & $\begin{array}{l}\square \text { Foot } \\
\square \text { Other } \\
\square \text { Truck } \\
\square \text { Not sure }\end{array}$ \\
\hline 4 & $\begin{array}{l}\square 0 \text { smokers } \\
\square<10 \\
\square 11-19 \\
\square 20 \text { or more } \\
\square \text { Not sure }\end{array}$ & $\begin{array}{l}\square \text { Yes } \\
\square \text { No } \\
\square \text { Not sure }\end{array}$ & $\begin{array}{l}\square \text { Yes } \\
\square \text { No } \\
\square \text { Not sure }\end{array}$ & $\begin{array}{l}\square \text { Bus/Tramway } \\
\square \text { Metro/Train } \\
\square \text { Car } \\
\square \text { Bicycle } \square \text { No Commute } \\
\square \text { Motorcycle }\end{array}$ & $\begin{array}{l}\square \text { Foot } \\
\square \text { Other } \\
\square \text { Truck } \\
\square \text { Not sure }\end{array}$ \\
\hline 5 & $\begin{array}{l}\square 0 \text { smokers } \\
\square<10 \\
\square 11-19 \\
\square 20 \text { or more } \\
\square \text { Not sure }\end{array}$ & $\begin{array}{l}\square \text { Yes } \\
\square \text { No } \\
\square \text { Not sure }\end{array}$ & $\begin{array}{l}\square \text { Yes } \\
\square \text { No } \\
\square \text { Not sure }\end{array}$ & $\begin{array}{l}\square \text { Bus/Tramway } \\
\square \text { Metro/Train } \\
\square \text { Car } \\
\square \text { Bicycle } \square \text { No Commute } \\
\square \text { Motorcycle }\end{array}$ & $\begin{array}{l}\square \text { Foot } \\
\square \text { Other } \\
\square \text { Truck } \\
\square \text { Not sure }\end{array}$ \\
\hline 6 & $\begin{array}{l}\square 0 \text { smokers } \\
\square<10 \\
\square 11-19 \\
\square 20 \text { or more } \\
\square \text { Not sure }\end{array}$ & $\begin{array}{l}\square \text { Yes } \\
\square \text { No } \\
\square \text { Not sure }\end{array}$ & $\begin{array}{l}\square \text { Yes } \\
\square \text { No } \\
\square \text { Not sure }\end{array}$ & $\begin{array}{l}\square \text { Bus/Tramway } \\
\square \text { Metro/Train } \\
\square \text { Car } \\
\square \text { Bicycle } \square \text { No Commute } \\
\square \text { Motorcycle }\end{array}$ & $\begin{array}{l}\square \text { Foot } \\
\square \text { Other } \\
\square \text { Truck } \\
\square \text { Not sure }\end{array}$ \\
\hline
\end{tabular}

Note: Space for more jobs is on the next page. 
EMPLOYMENT HISTORY (Cont'd)

\begin{tabular}{|c|c|c|c|c|c|}
\hline $\begin{array}{l}\text { Job } \\
\text { No. }\end{array}$ & $\begin{array}{l}\text { At this job, on } \\
\text { average, about } \\
\text { how many people } \\
\text { around you } \\
\text { smoked? }\end{array}$ & $\begin{array}{l}\text { While on this job, } \\
\text { did you ever work } \\
\text { near diesel engines } \\
\text { or other types of } \\
\text { engines? }\end{array}$ & $\begin{array}{l}\text { While on this job, } \\
\text { did you ever smell } \\
\text { diesel exhaust or } \\
\text { other types of } \\
\text { engine exhaust? }\end{array}$ & $\begin{array}{l}\text { How did you usually comn } \\
\text { job? }\end{array}$ & nute to this \\
\hline 7 & $\begin{array}{l}\square 0 \text { smokers } \\
\square<10 \\
\square 11-19 \\
\square 20 \text { or more } \\
\square \text { Not sure }\end{array}$ & $\begin{array}{l}\square \text { Yes } \\
\square \text { No } \\
\square \text { Not sure }\end{array}$ & $\begin{array}{l}\square \text { Yes } \\
\square \text { No } \\
\square \text { Not sure }\end{array}$ & $\begin{array}{l}\square \text { Bus/Tramway } \\
\square \text { Metro/Train } \\
\square \text { Car } \\
\square \text { Bicycle } \square \text { No Commute } \\
\square \text { Motorcycle }\end{array}$ & $\begin{array}{l}\square \text { Foot } \\
\square \text { Other } \\
\square \text { Truck } \\
\square \text { Not sure }\end{array}$ \\
\hline 8 & $\begin{array}{l}\square 0 \text { smokers } \\
\square<10 \\
\square 11-19 \\
\square 20 \text { or more } \\
\square \text { Not sure }\end{array}$ & $\begin{array}{l}\square \text { Yes } \\
\square \text { No } \\
\square \text { Not sure }\end{array}$ & $\begin{array}{l}\square \text { Yes } \\
\square \text { No } \\
\square \text { Not sure }\end{array}$ & $\begin{array}{l}\square \text { Bus/Tramway } \\
\square \text { Metro/Train } \\
\square \text { Car } \\
\square \text { Bicycle } \square \text { No Commute } \\
\square \text { Motorcycle }\end{array}$ & $\begin{array}{l}\square \text { Foot } \\
\square \text { Other } \\
\square \text { Truck } \\
\square \text { Not sure }\end{array}$ \\
\hline 9 & $\begin{array}{l}\square 0 \text { smokers } \\
\square<10 \\
\square 11-19 \\
\square 20 \text { or more } \\
\square \text { Not sure }\end{array}$ & $\begin{array}{l}\square \text { Yes } \\
\square \text { No } \\
\square \text { Not sure }\end{array}$ & $\begin{array}{l}\square \text { Yes } \\
\square \text { No } \\
\square \text { Not sure }\end{array}$ & $\begin{array}{l}\square \text { Bus/Tramway } \\
\square \text { Metro/Train } \\
\square \text { Car } \\
\square \text { Bicycle } \square \text { No Commute } \\
\square \text { Motorcycle }\end{array}$ & $\begin{array}{l}\square \text { Foot } \\
\square \text { Other } \\
\square \text { Truck } \\
\square \text { Not sure }\end{array}$ \\
\hline 10 & $\begin{array}{l}\square 0 \text { smokers } \\
\square<10 \\
\square 11-19 \\
\square 20 \text { or more } \\
\square \text { Not sure }\end{array}$ & $\begin{array}{l}\square \text { Yes } \\
\square \text { No } \\
\square \text { Not sure }\end{array}$ & $\begin{array}{l}\square \text { Yes } \\
\square \text { No } \\
\square \text { Not sure }\end{array}$ & $\begin{array}{l}\square \text { Bus/Tramway } \\
\square \text { Metro/Train } \\
\square \text { Car } \\
\square \text { Bicycle } \square \text { No Commute } \\
\square \text { Motorcycle }\end{array}$ & $\begin{array}{l}\square \text { Foot } \\
\square \text { Other } \\
\square \text { Truck } \\
\square \text { Not sure }\end{array}$ \\
\hline 11 & $\begin{array}{l}\square 0 \text { smokers } \\
\square<10 \\
\square 11-19 \\
\square 20 \text { or more } \\
\square \text { Not sure }\end{array}$ & $\begin{array}{l}\square \text { Yes } \\
\text { No } \\
\square \text { Not sure }\end{array}$ & $\begin{array}{l}\square \text { Yes } \\
\square \text { No } \\
\square \text { Not sure }\end{array}$ & $\begin{array}{l}\square \text { Bus/Tramway } \\
\square \text { Metro/Train } \\
\square \text { Car } \\
\square \text { Bicycle } \square \text { No Commute } \\
\square \text { Motorcycle }\end{array}$ & $\begin{array}{l}\square \text { Foot } \\
\square \text { Other } \\
\square \text { Truck } \\
\square \text { Not sure }\end{array}$ \\
\hline 12 & $\begin{array}{l}\square 0 \text { smokers } \\
\square<10 \\
\square 11-19 \\
\square 20 \text { or more } \\
\square \text { Not sure }\end{array}$ & $\begin{array}{l}\square \text { Yes } \\
\square \text { No } \\
\square \text { Not sure }\end{array}$ & $\begin{array}{l}\square \text { Yes } \\
\square \text { No } \\
\square \text { Not sure }\end{array}$ & $\begin{array}{l}\square \text { Bus/Tramway } \\
\square \text { Metro/Train } \\
\square \text { Car } \\
\square \text { Bicycle } \square \text { No Commute } \\
\square \text { Motorcycle }\end{array}$ & $\begin{array}{l}\square \text { Foot } \\
\square \text { Other } \\
\square \text { Truck } \\
\square \text { Not sure }\end{array}$ \\
\hline
\end{tabular}

Note: If more than 12 jobs, please use an additional page. Interviewer will inquire about more jobs, if applicable. 


\section{EMPLOYMENT HISTORY (Cont'd)}

55. Referring to the jobs you listed in question \#52, we would like to know if you ever worked for more than $\mathbf{6}$ months in any of the following specific jobs. If your work in any of these industries involved primarily office and administrative tasks, please indicate this by checking the box in the far right column.

\begin{tabular}{|c|c|c|c|}
\hline Industry & & $\begin{array}{c}\text { Job number(s) from } \\
\text { Question } 52\end{array}$ & Office/Admin. \\
\hline Aircraft maintenance & Yes $\square$ No & & $\square$ \\
\hline Building construction & Yes $\mathrm{N}$ No & & 0 \\
\hline Fire-fighting & Yes $\square$ No & & D \\
\hline Maritime industry & $\begin{array}{ll}\text { Yes } & \text { No } \square \\
\end{array}$ & & 0 \\
\hline Food services & $\begin{array}{ll}\text { Yes } & \text { No } \square\end{array}$ & & $\square$ \\
\hline Landscaping & Yes $\square$ No & & 0 \\
\hline Agriculture & Yes $\square$ No & & 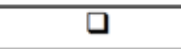 \\
\hline Gas distribution as station attendant & Yes $\square$ No & & 0 \\
\hline Postal services as mail carrier & Yes $\square$ No $\square$ & & 口 \\
\hline Mining & Yes $\square$ No & & 口 \\
\hline Oil refining industry & Yes $\square$ No $\square$ & & $\square$ \\
\hline Police detachment & Yes $\square$ No $\square$ & & 口 \\
\hline Plumbing & Yes $\square$ No & & 口 \\
\hline Road construction and maintenance & Yes ${ }^{\prime}$ No $\square$ & & 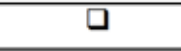 \\
\hline Roofing & Yes $\square$ No & & a \\
\hline Waterproofing & Yes $\square$ No & & $\square$ \\
\hline Rubber industry & Yes $\square$ No $\square$ & & 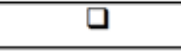 \\
\hline Metalworking & Yes $\square$ No & & $\overline{0}$ \\
\hline Traffic/warehousing/shipping & Yes $\square$ No & & 0 \\
\hline Production of coke & Yes $\square$ No & & 0 \\
\hline Manufacture of electrodes & $\begin{array}{ll}\text { Yes } & \text { No } \square \\
\end{array}$ & & D \\
\hline Gas works & Yes $\square$ No & & a \\
\hline Tar distillery & Yes $\square$ No & & 0 \\
\hline Production of aluminum & $\begin{array}{ll}\text { Yes } & \text { No } \square\end{array}$ & & D \\
\hline
\end{tabular}




\section{EMPLOYMENT HISTORY (Cont'd)}

56. In any of your jobs we have already asked about, did you carry out any of the following tasks?

\begin{tabular}{|c|c|c|}
\hline Tasks & & $\begin{array}{c}\text { Job number(s) from } \\
\text { Question } 52\end{array}$ \\
\hline Operating a boat engine & Yes & \\
\hline Metal working (grinding, cutting, extruding, machining) & Yes $\square$ No & \\
\hline Furnace work & Yes $\square$ No & \\
\hline Fire fighting & Yes No & \\
\hline Cooking & Yes $\square$ No & \\
\hline Baking bread products or pastries & Yes $\square$ No $\square$ & \\
\hline Operating coke oven & Yes $\square$ No & \\
\hline Chimney sweeping & Yes $\square$ No & \\
\hline Brick-laying & Yes $\mathrm{No}$ & \\
\hline Masonry & Yes No & \\
\hline Carpentry & Yes $\square$ No & \\
\hline Repair electrical equipment or fixtures & Yes $\square$ No & \\
\hline Driving a forklift & Yes $\square$ No & \\
\hline Bartending & Yes $\square$ No & \\
\hline Waitressing & Yes $\mathrm{No}$ & \\
\hline Gardening & Yes $\square$ No & \\
\hline Waste incineration & Yes $\square$ No & \\
\hline
\end{tabular}

57. In any of your jobs we have already asked about, did you handle any of the following materials?

\begin{tabular}{|c|c|c|}
\hline Materials & & $\begin{array}{c}\text { Job number(s) } \\
\text { from Question } 52\end{array}$ \\
\hline Coal tar & Yes $\square$ No Don't Know & \\
\hline Pitch & Yes & \\
\hline Asphalt & Yes & \\
\hline Bitumen & Yes & \\
\hline Creosote & Yes & \\
\hline Soot & Yes & \\
\hline Anthracene oil & Yes & \\
\hline Cutting oils & Yes $\square$ No $\square$ Don't Know & \\
\hline
\end{tabular}




\section{INCOME}

The following 2 questions are related to your household income. This information is very important and will only be used for the purposes of this research study. Please be assured that, like all other information you have provided, these answers will be kept strictly confidential.

58. Thinking back to 2 years ago, how many people were living in your household at that time?

59. Thinking back to 2 years ago, what was the total income for all people living in your household from all sources, before taxes? Sources include income from all earnings (wages and salaries), income from all government sources and all investment income (such as retirement funds).

No income

Less than $\$ 15,000$

$\$ 15,000$ to $\$ 19,999$

$\$ 20,000$ to $\$ 29,999$

$\$ 30,000$ to $\$ 39,999$
$\$ 40,000$ to $\$ 59,999$

$\$ 60,000$ to $\$ 79,999$

$\$ 80,000$ to $\$ 99,999$

$\$ 100,000$ or more

Not Stated

Thank you very much for completing this questionnaire! Because we want to be able to use all the information you have provided, we would greatly appreciate it if you would please take a moment to review each page making sure that you did not skip any pages.

In the space below, please add any comments you wish, and thank you again for the information you have provided! 


\section{Appendix C}

\section{Additional Data Tables}

Table C-1: Bivariate analyses for post- and premenopausal women for all covariates, except age (matching variable)

\begin{tabular}{|c|c|c|}
\hline & $\begin{array}{l}\text { POSTMENOPAUSAL } \\
\text { WOMEN }(\mathbf{N}=\mathbf{1 , 1 9 6 )}\end{array}$ & $\begin{array}{l}\text { PREMENOPAUSAL } \\
\text { WOMEN (N=711) }\end{array}$ \\
\hline CHARACTERISTICS & OR $(95 \% \mathrm{CI})$ & OR $(95 \% \mathrm{CI})$ \\
\hline \multicolumn{3}{|l|}{ ETHNICITY } \\
\hline White & 1 & 1 \\
\hline East Asian & $2.88(2.08,3.99)$ & $2.43(1.70,3.48)$ \\
\hline Other & $1.86(1.31,2.66)$ & $1.35(0.88,2.09)$ \\
\hline \multicolumn{3}{|l|}{ EDUCATION, highest level achieved } \\
\hline High school or less & 1 & 1 \\
\hline Trade certificate/Completed community college/CEGEP & $0.67(0.50,0.90)$ & $0.74(0.48,1.15)$ \\
\hline University, graduate, or professional degree & $0.50(0.38,0.66)$ & $0.56(0.38,0.85)$ \\
\hline \multicolumn{3}{|l|}{ HOUSEHOLD INCOME } \\
\hline$<\$ 40,000$ & 1 & 1 \\
\hline$\$ 40,000$ to $\$ 59,999$ & $0.57(0.39,0.84)$ & $0.60(0.35,1.03)$ \\
\hline$\$ 60,000$ to $\$ 79,999$ & $0.47(0.30,0.74)$ & $0.43(0.24,0.79)$ \\
\hline$\$ 80,000$ to $\geq \$ 100,000$ & $0.52(0.32,0.86)$ & $0.50(0.27,0.92)$ \\
\hline No income & $0.60(0.39,0.91)$ & $0.25(0.13,0.49)$ \\
\hline Not stated & $0.31(0.21,0.47)$ & $0.48(0.29,0.78)$ \\
\hline
\end{tabular}




\begin{tabular}{|c|c|c|}
\hline & $\begin{array}{l}\text { POSTMENOPAUSAL } \\
\text { WOMEN }(\mathbf{N}=\mathbf{1 , 1 9 6})\end{array}$ & $\begin{array}{l}\text { PREMENOPAUSAL } \\
\text { WOMEN (N=711) }\end{array}$ \\
\hline CHARACTERISTICS & OR $(95 \% \mathrm{CI})$ & OR $(95 \% \mathrm{CI})$ \\
\hline \multicolumn{3}{|c|}{ \# FIRST-DEGREE RELATIVES WITH BREAST CANCER } \\
\hline None & 1 & 1 \\
\hline At least one & $1.65(1.22,2.24)$ & $1.45(0.95,2.22)$ \\
\hline AGE AT MENARCHE & $1.06(0.99,1.14)$ & $0.96(0.87,1.07)$ \\
\hline \multicolumn{3}{|l|}{ AGE AT FIRST BIRTH } \\
\hline Never pregnant & 1 & 1 \\
\hline$<29$ & $1.27(0.92,1.76)$ & $1.47(0.96,2.27)$ \\
\hline$\geq 29$ & $1.13(0.81,1.58)$ & $1.62(1.12,2.35)$ \\
\hline \multicolumn{3}{|l|}{ \# OF PREGNANCIES } \\
\hline 0 & 1 & 1 \\
\hline$<2$ & $1.57(1.02,2.42)$ & $1.81(1.12,2.92)$ \\
\hline$\geq 2$ & $1.14(0.84,1.55)$ & $1.53(1.07,2.2)$ \\
\hline \multicolumn{3}{|c|}{ DURATION OF BREASTFEEDING, months } \\
\hline$<12$ & 1 & 1 \\
\hline 12 to $<24$ & $0.67(0.48,0.93)$ & $0.70(0.48,1.02)$ \\
\hline$\geq 24$ & $0.87(0.59,1.29)$ & $0.82(0.50,1.37)$ \\
\hline \multicolumn{3}{|c|}{ AGE AT BILATERAL OOPHORECTOMY } \\
\hline Never had & 1 & N/A \\
\hline$<40$ & $0.93(0.38,2.24)$ & N/A \\
\hline 40 to $<50$ & $0.93(0.53,1.64)$ & N/A \\
\hline
\end{tabular}




\begin{tabular}{|c|c|c|}
\hline & $\begin{array}{l}\text { POSTMENOPAUSAL } \\
\text { WOMEN }(\mathbf{N}=1,196)\end{array}$ & $\begin{array}{l}\text { PREMENOPAUSAL } \\
\text { WOMEN (N=711) }\end{array}$ \\
\hline CHARACTERISTICS & OR $(95 \% \mathrm{CI})$ & OR $(95 \% \mathrm{CI})$ \\
\hline$\geq 50$ & $0.87(0.51,1.49)$ & N/A \\
\hline \multicolumn{3}{|l|}{ OC USE } \\
\hline Never used & 1 & 1 \\
\hline Used & $0.71(0.56,0.90)$ & $0.42(0.31,0.58)$ \\
\hline \multicolumn{3}{|l|}{ HRT USE } \\
\hline Never used & 1 & 1 \\
\hline Used & $0.92(0.73,1.16)$ & $0.76(0.39,1.47)$ \\
\hline AVERAGE ALCOHOL CONSUMPTION, drinks/week based on age & $0.87(0.84,0.91)$ & $0.88(0.83,0.93)$ \\
\hline \multicolumn{3}{|l|}{ SMOKING STATUS } \\
\hline Non-smoker & 1 & 1 \\
\hline Former & $0.91(0.72,1.16)$ & $0.89(0.64,1.24)$ \\
\hline Current & $0.92(0.58,1.46)$ & $0.72(0.38,1.40)$ \\
\hline AVERAGE LIFETIME PACKYEARS & $1.00(1.00,1.01)$ & $1.01(0.99,1.03)$ \\
\hline BMI, $\mathrm{kg} / \mathrm{m}^{2}$ & $1.05(1.02,1.07)$ & $0.98(0.96,1.02)$ \\
\hline
\end{tabular}

